Paula Fernanda Alves da Cunha Gorzoni

\title{
PONDERAÇÃO E CRITÉRIOS RACIONAIS DE DECIDIBILIDADE NA ARGUMENTAÇÃO JUDICIAL
}

Dissertação apresentada à Faculdade de Direito da Universidade de São Paulo como requisito à obtenção do título de Mestre em Direito do Estado, sob a orientação do Professor Titular Luís Virgílio Afonso da Silva.

Universidade de São Paulo

Faculdade de Direito

São Paulo - 2011 
Banca examinadora:

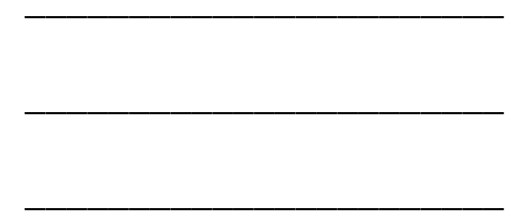


A meus pais 


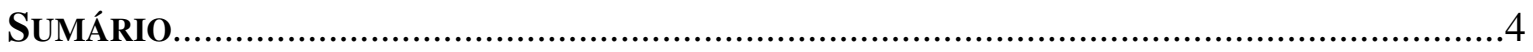

AGRADECIMENTOS

\section{Capítulo 1}

INTRODUÇÃo

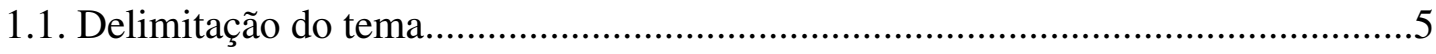

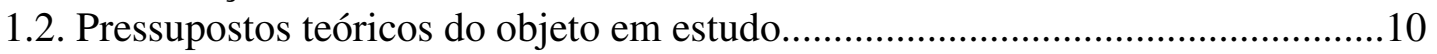

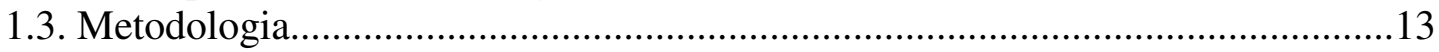

\section{Capítulo 2}

\section{CRíticas À PONDERAÇÃo}

2.1. Introdução.

2.2. A crítica de Habermas: a "jurisprudência de valores" do tribunal constitucional alemão.

2.3. Direitos subjetivos e princípios objetivos no tribunal constitucional alemão......22

2.4. Teorias de direitos fundamentais e críticas à teoria dos princípios......................25

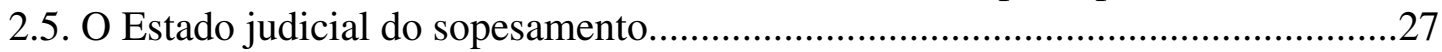

2.6. Sopesamento e acumulação de conhecimentos nas decisões................................29

2.7. Proporcionalidade e a dispensabilidade de se sopesar direitos no exame.............30

2.8. Concretização dos direitos fundamentais em jogo no sopesamento.....................33

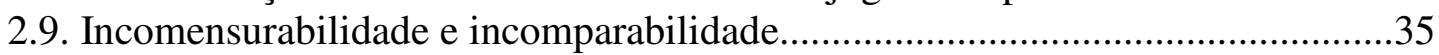

2.10. Sopesamento como metáfora e indefinição de sua linguagem............................41

\section{Capítulo 3}

MODELO E ESTRUTURA DE SOPESAMENTO

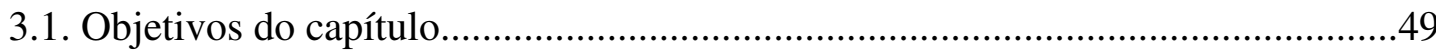

3.2. Esclarecimento preliminar: qual a racionalidade para o direito?.......................49

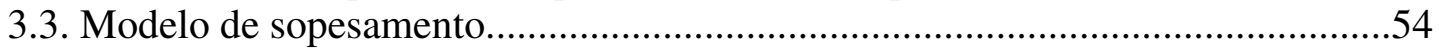

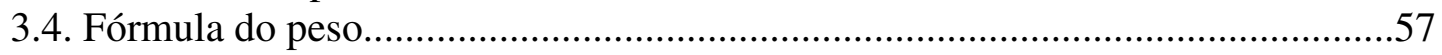

3.5. Variações ou complementações do modelo de sopesamento e fórmula do

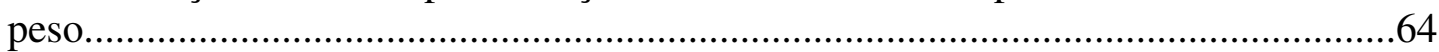

3.6. Uso de critérios econômicos no sopesamento.................................................67

3.7. Exigências de racionalidade do discurso jurídico: regras da argumentação

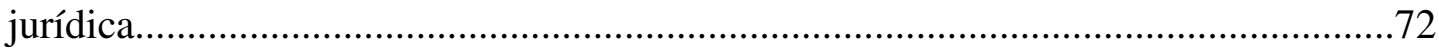

3.8. Modelo de sopesamento orientado por regras.................................................75

3.9. Critérios complementares para guiar o sopesamento de forma racional...............77

3.10. Parâmetros de controle para a sociedade........................................................ 78

\section{Capítulo 4}

ESTUDO DE CASO - DECISÃO DE BUSCA DE DADOS PESSOAIS

4.1. Contexto.

4.2. Aplicação do sopesamento para a resolução do caso......................................82

4.3. Resumo da estrutura da decisão analisada e seus critérios para o

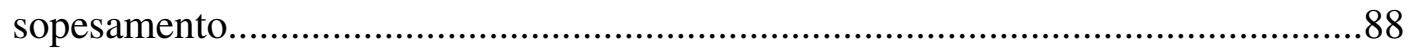


Existem diversas colaborações durante o percurso de um trabalho acadêmico, apesar deste ser geralmente apontado como uma atividade solitária. Por isso, gostaria de agradecer às pessoas envolvidas no processo de desenvolvimento do mestrado.

Em primeiro lugar, ao meu orientador Virgílio Afonso da Silva, agradeço todas as críticas, sugestões, comentários, apoio e acompanhamento desde o início da minha carreira acadêmica.

À Fundação de Amparo à Pesquisa do Estado de São Paulo (Fapesp), agradeço a bolsa de pesquisa concedida para a realização deste mestrado. Ao Goethe-Institut São Paulo, agradeço a bolsa de curso de alemão em Munique. Esta bolsa foi importante não somente para o estudo do idioma em si, mas também por ter me possibilitado utilizar a biblioteca da Universidade de Munique em período essencial para a pesquisa.

Aos professores Humberto Ávila e Marcos Paulo Veríssimo, agradeço as críticas e comentários na banca de qualificação. Aos professores Diogo R. Coutinho e Jean Paul Rocha, as sugestões para o meu projeto de qualificação feitas nas aulas da disciplina “Pesquisa em Direito", da pós-graduação.

Ao Prof. Robert Alexy, agradeço o convite e a estadia de pesquisa durante o semestre de inverno 2010/2011 na Universidade de Kiel. O tempo em que passei como pesquisadora visitante foi muito importante para o desenvolvimento do trabalho. Agradeço também a todas as pessoas ligadas à cadeira do Prof. Alexy, especialmente Andrea Neisius, Carsten Bäcker, Daniel Deba, Jorge Portocarrero, Kristian Klaus, Christoph Kallmeyer, Lars Cordes, Alexandre Travessoni e Fernando Leal. Agradeço ao Fernando a leitura atenta dos esboços do projeto de qualificação e tanto ao Fernando quanto ao Alexandre a amizade e o apoio durante minha estadia em Kiel. Aos amigos de WG Hendrik, Desireé, Nadja e Mauro e demais amigos de Uni e Erasmus Kiel.

Aos professores e pós-graduandos participantes do seminário de pesquisa, realizado mensalmente pelo meu orientador, e aos monitores de direitos fundamentais, agradeço os debates feitos durante este período de desenvolvimento da pesquisa.

Ao Núcleo Direito e Democracia do Centro Brasileiro de Análise e Planejamento (NDD-CEBRAP) e à Sociedade Brasileira de Direito Público (SBDP), nominalmente a Carlos Ari e Roberta Sundfeld. À equipe de coordenação da Escola de Formação Henrique Motta Pinto, Flávia Annenberg e Fillipi Borges, e também às turmas dos anos de 2009 e 2010. Ao Rodrigo Pagani, coordenador acadêmico da SBDP. 
Aos amigos de pós-graduação Caroline Rocha, Carolina Martins, Amanda Guazzelli e Rodrigo Nitrini. À Bruna Pretzel, agradeço a grande amizade e grande apoio também na vida acadêmica.

Aos amigos de longa data da turma 177 da São Francisco, especialmente Marcello Stievano, Marília Grespan, Natália Diniz, Tatiana Shiroma, Thiago Dias, William Laureano e Willians Ogata.

Aos novos amigos da turma 181 da São Francisco, especialmente Jonathas Soler e Rodrigo Gruppi. A Rodrigo Leal da Silva, agradeço a grande amizade, além dos muros do Goethe-Institut e da São Francisco. Também às amigas Mariana Chaimovich, Maíra Martins e Maria Alice Rodrigues e aos amigos de Berlim.

Aos meus pais, Milton Luiz Gorzoni e Regina Celi Alves da Cunha, que me deram o apoio essencial para que tudo isso acontecesse. 


\subsection{Delimitação do tema}

Atualmente, o recurso à ponderação ou ao sopesamento como método de decisão e de resolução de colisões entre princípios e aplicação de direitos fundamentais vem sendo adotado de forma freqüente tanto pela literatura jurídica quanto pela jurisprudência nacional e internacional. Isso é facilmente observado não somente por meio dos inúmeros trabalhos teóricos sobre o tema produzidos nos últimos anos, ${ }^{1}$ mas também por meio da jurisprudência de diversos tribunais, como, por exemplo, o Supremo Tribunal Federal $(\mathrm{STF}){ }^{2}$

No plano da discussão internacional, é possível identificar alguns autores como "entusiastas da ponderação", que classificam o método como a forma mais adequada de argumentar e decidir nos tribunais. ${ }^{3}$ Outros destacam a expansão da idéia de ponderação, que vem se tornando um método dominante nas decisões judiciais em vários países, inclusive naqueles de tradição common law, além do uso em tribunais de caráter internacional como a Corte Européia de Direitos Humanos e organizações de comércio internacional. $^{4}$

$1 \quad$ No contexto brasileiro, dentre as obras sobre o assunto, destacam-se os trabalhos de Ana Paula de Barcellos, Ponderação, racionalidade e atividade jurisdicional, e Daniel Sarmento, A ponderação de interesses na Constituição Federal. Rio de Janeiro: Lumen Juris, 2000. Além disso, existem também trabalhos que tratam do tema, porém não de forma direta, como, por exemplo: Wilson Steinmetz, Colisão de direitos fundamentais e princípio da proporcionalidade. Porto Alegre: Livraria do Advogado, 2001, Gilmar Ferreira Mendes, Direitos fundamentais e controle de constitucionalidade. 2. ed., São Paulo: Celso Bastos: Instituto Brasileiro de Direito Constitucional, 1999, Humberto Ávila, Teoria dos princípios, São Paulo: Malheiros, 2003, entre outros.

${ }_{2}$ O STF utiliza o método nas mais variadas decisões. Em uma busca de acórdãos no site do STF (www.stf.gov.br), foi possível encontrar por meio da expressão "ponderação" 131 decisões. É claro que nem todas possuem direta conexão com o tema, mas grande parte se relaciona com o objeto em estudo: em análise, foi possível visualizar pelo menos 67 acórdãos como parte desse universo. Também foi possível observar que o tribunal utiliza a ponderação nas situações mais diversas, em discussões sobre direitos fundamentais, direito econômico, penal, administrativo, tributário, entre outros. Busca realizada em 16/03/2010. Pesquisas extensivas de jurisprudência sobre o tema, cf., por exemplo: Bruno Ramos Pereira, $O$ uso da proporcionalidade no Supremo Tribunal Federal. São Paulo: dissertação de mestrado, Faculdade de Direito da Universidade de São Paulo, 2009.

3 Cf., por exemplo, David Beatty, The Ultimate Rule of Law. Oxford University Press: 2002.

4 Cf. Stone Alec Stone Sweet e Jud Mathews, "Proportionality Balancing and Global Constitutionalism", Columbia Journal of Transnational Law 47.1 (2008), T. Alexander Aleinikoff., "Constitutional Law in the Age of Balancing", Yale Law Journal 96 (1987), Dieter Grimm, "Proportionality in Canadian and German Constitutional Jurisprudence", University of Toronto Law Journal 57 (2007), Stravros Tsakyrakis, "Proportionality: An assault on human rights?", International Journal of Constitutional Law 3 (2009), Jacco Bomhoff, "Balancing, the Global and the Local: Judicial Balancing as a Problematic Topic in Comparative (Constitutional) Law", Hastings International \& Comparative Law Review 31 (2008), 
A expansão do método tem se tornado um fator de reflexão no debate jurídico, estando inserida na atual discussão sobre a migração de idéias constitucionais. ${ }^{5}$ A expressão "migração" é utilizada como uma nova metáfora para o direito comparado e pode ser aplicada tanto para questões referentes a citações de casos de tribunais estrangeiros, como para a importação de métodos de interpretação desenvolvidos em outros países. Nesse debate, é levantada, dentre várias hipóteses, a de que o aumento do uso de direito comparado nas decisões dos tribunais nas últimas décadas poderia sugerir que as cortes constitucionais estariam engajadas em uma interpretação comum. ${ }^{6}$

No entanto, penso que a discussão sobre a migração de idéias constitucionais e o uso dessas idéias em países diferentes passa inevitavelmente pela questão relacionada a como adaptar métodos e interpretações provenientes de contextos diversos, sem que esse empréstimo constitucional se torne um mero "transplante", ou seja, apenas uma reprodução irrefletida sem a observância das culturas de cada país. ${ }^{7}$ Nos Estados Unidos, por exemplo, esse uso é visto com muitas ressalvas, inclusive por juízes da própria Suprema Corte. ${ }^{8} \mathrm{O}$ juiz Scalia afirma que o empréstimo constitucional nada mais é que a imposição de preferências sem justificativas, permitindo manipulação. Isso porque poderia ser aplicado algum método de decisão ou entendimento jurisprudencial descontextualizado da forma como foi desenvolvido no país de origem e isso seria aproveitado pelo juiz da maneira mais conveniente. Além disso, fala-se, nesse país, que o uso de citação estrangeira atrapalharia a linha de precedentes, a democracia e a soberania da nação. ${ }^{9}$

pp. 555 e ss., Carlos Bernal Pulido, "Grundrechtsprinzipien in Spanien: Rationalität und Grenzen der Abwägung", in Jan-R. Sieckmann, Die Prinzipientheorie der Grundrechte, Baden-Baden: Nomos, 2007, Julian Rivers, „Proportionality and Variable Intensity of Review”, Cambridge Law Journal 65 (1) (2006), Alan David Patrick Brady, A Structural, Institutionally Sensitive Model of Proportionality and Deference under the Human Rights Act 1998, Tese de doutorado apresentada ao Departamento de Direito da London School of Economics, 2009, Frank M. Coffin, "Judicial Balancing: The Protean Scales of Justice”, New York University Law Review (1988), Luisa Conesa, "The Tropicalization of Proportionality Balancing: The Colombian and Mexican Examples" (2008), Cornell Law School Inter-University Graduate Student Conference Papers, Paper 13. http://scholarship.law.cornell.edu/lps_clacp/13. Acesso em: 13.12.2010.

Sobre o tema, cf. Sujit Choudhry (Ed.), The Migration of Constitutional Ideas. Cambridge: Cambridge University Press, 2006.

$6 \quad$ Cf. Michael Ramsey; Sujit Choudhry, "Migration as a new metaphor in comparative constitutional law", in Sujit Choudhry (Ed.), The Migration of Constitutional Ideas, p. 2.

7 Diferença entre empréstimo e transplante: Sujit Choudhry, "Migration as a new metaphor in comparative constitutional law", p. 16.

O caso americano é especial, no sentido que o juiz da Suprema Corte é visto como uma autoridade isolada, diferente do caso francês, por exemplo. O uso de fórmulas por esses juízes é muito criticado, já que métodos restringiriam a liberdade argumentativa dos interlocutores. A aplicação de fórmulas seria mecânica, reduzindo o juiz a um mero observador. Sobre a diferença entre EUA e França, ver Mitchel de S.-O.-L.'E. Lasser, Judicial Deliberations: a Comparative Analysis of Judicial Transparancy and Legitimacy. Oxford: Oxford University Press, 2009, pp. 343 e ss.

9 Cf. Sujit Choudhry, Migration as a new metaphor in comparative constitutional law”, p. 11. 
Mesmo sendo um país mais fechado à recepção de idéias de outros ordenamentos jurídicos, segundo autores que estudam a jurisprudência da Suprema Corte norteamericana esta vem aplicando a ponderação nos últimos tempos, ${ }^{10}$ algumas vezes até de forma pouco questionadora. ${ }^{11}$ É o que Alec Stone Sweet \& Jud Mathews ressaltam em estudo sobre o uso global do sopesamento e da proporcionalidade, afirmando que hoje os dois métodos são considerados sem maiores questionamentos por muitos autores. ${ }^{12}$

Todo esse entusiasmo apontado acaba desviando à atenção de eventuais problemas e dificuldades na aplicação do método. Considerando que o sopesamento é utilizado na maioria das vezes em decisões judiciais, inclusive por tribunais constitucionais de vários países, a discussão está inserida não somente no âmbito aplicação do método, mas também no fato de que a legitimidade dos juízes provém do desenvolvimento de argumentação coerente e consistente. ${ }^{13}$ Sendo o judiciário uma autoridade contramajoritária, ${ }^{14}$ seu déficit democrático pode ser resolvido justamente por meio da argumentação, da motivação das sentenças. Como os juízes não são eleitos democraticamente, a legitimidade de seu poder não depende de sua origem, mas de seu exercício, das razões que podem aduzir para justificar suas decisões. ${ }^{15}$ Há autores que inclusive afirmam que a legitimidade das instituições judiciais depende da sua metodologia interpretativa. ${ }^{16}$ Outros autores ainda falam sobre uma possível mudança na estruturação dos poderes a partir da utilização do método. ${ }^{17}$ Desse modo, a discussão sobre a aplicação freqüente do sopesamento como método de decisão e argumentação também está inserida na questão de legitimidade do poder judiciário.

10 Cf. Mattias Kumm, "Political Liberalism and the Structure of Rights: On the Place and Limits of the Proportionality Requirement". In Law, Rights, Discourse: the Legal Philosophy of Robert Alexy, George Pavlakos (ed.), 2007.

$11 \quad$ Cf. T. Alexander Aleinikoff, "Constitutional Law in the Age of Balancing”, p.

12 Cf. Alec Stone Sweet \& Jud Mathews, "Proportionality Balancing and Global Constitutionalism", p.

4.

13 Segundo MacCormick, o requisito da consistência corresponderia a um grupo de proposições, no qual cada uma pode ser, sem contradição, "afirmada em conjunto com cada uma das outras e com a conjunção de todas as outras". Já a coerência "é a propriedade de um grupo de proposições que, tomadas em conjunto, "faz sentido" na sua totalidade". Cf. Neil MacCormick, Retórica e Estado de direito, Rio de Janeiro: Elsevier, 2008, p. 248.

14 Como na definição de Alexander Bickel, The Least Dangerous Branch: The Supreme Court at the Bar of Politics. 2. ed. New Heaven: Yale University Press, 1986.

15 Cf. Manuel Atienza, El sentido del derecho. 3. ed. Barcelona: Ariel, 2007, p. 265.

16 Cf. Sujit Choudhry, "Migration as a new metaphor in comparative constitutional law", p. 4.

17 Por exemplo, cf. Julian Rivers, "Proportionality and Variable Intensity of Review", p. 176 e Bernhard Schlink, "Der Grundsatz der Verhältinismäßigkeit”, pp. 447 e ss. 
Com o uso em evidência da proporcionalidade e da ponderação, ${ }^{18}$ poder-se-ia perguntar intuitivamente o porquê dos juízes utilizarem com tanta frequiência o método. Seria justamente por ser um método aberto, no qual é possível justificar qualquer opinião sem maiores fundamentações? Esse é um dos argumentos-base dos críticos da ponderação. Böckenförde, por exemplo, aborda esse problema por meio de um exemplo: os alunos do autor se sentiam confortáveis em aplicar a ponderação em provas com casos práticos, pois consideravam que qualquer resposta que dessem seria correta. ${ }^{19}$

Nesse trabalho, pretende-se partir desse cenário de aplicação em ascensão do sopesamento para se investigar uma das principais críticas do debate jurídico internacional: o desenvolvimento do método da ponderação e a possibilidade da existência de critérios racionais de decidibilidade na sua aplicação. A pergunta inicial, de forma simplificada e genérica, consiste em questionar se seria possível considerar o sopesamento um método racional na interpretação e decisão de colisões entre direitos fundamentais, no intuito de se investigar as possibilidades de fundamentação dos juízos ponderativos, assim como as pretensões de racionalidade, correção ou objetividade que se podem relacionar à técnica. Objetiva-se observar o desenvolvimento do método nas decisões judiciais e examinar as possibilidades de critérios racionais de decidibilidade presentes ou não na sua estrutura e por meio da argumentação relacionada a sua aplicação.

Para iniciar o trabalho, no entanto, é preciso fazer alguns esclarecimentos sobre os pontos de partidos teóricos centrais ao desenvolvimento da pesquisa. É o que se pretende fazer no próximo tópico.

\subsection{Pressupostos teóricos do objeto em estudo}

O objeto deste trabalho depende da forma como se concebe princípios e regras. Por isso, ainda que não seja diretamente ligada ao tema em si, faz-se necessário traçar algumas considerações sobre a distinção entre esses dois tipos de normas. Conforme afirma Robert Alexy, essa distinção constitui "a base da teoria da fundamentação no âmbito dos direitos

\footnotetext{
18 A ponderação equivale à terceira sub-regra da proporcionalidade. Esse ponto será abordado com maiores detalhes posteriormente, nos pressupostos teóricos do trabalho.

19 Cf. Virgílio Afonso da Silva, "Ponderação e objetividade na interpretação constitucional", in Ronaldo Porto Macedo Jr. E Catarina Helena Cortada Barbieri (org.), Direito e Interpretação: racionalidades $e$ instituições, São Paulo: Saraiva, 2011, p. 365 e Ernst-Wolfgang Böckenförde, "Vier Thesen zur Kommunitarismus-Debatte", in Peter Siller / Bertram Keller (Hrsg.), Rechtsphilosophische Kontroversen der Gegenwart. Baden-Baden: Nomos, 1999, pp. 85-86.
} 
fundamentais e uma chave para a solução de problemas centrais da dogmática dos direitos fundamentais". 20

A distinção entre regras e princípios não é uma discussão nova. ${ }^{21}$ A aqui adotada não é em relação ao grau de generalidade ou abstração das normas, como é usualmente descrita pela doutrina tradicional. Trata-se de uma distinção qualitativa. Isso porque, seguindo a concepção de Alexy, princípios são mandamentos de otimização, ou seja, normas que ordenam que algo seja feito na maior medida possível, de acordo com as possibilidades fáticas e jurídicas do caso concreto. $^{22}$ Por outro lado, regras são mandamentos definitivos, ou seja, normas que só podem ser cumpridas ou não, sendo realizadas por meio da lógica "tudo ou nada". Essa distinção implica formas diversas de se solucionar conflitos entre regras e colisões entre princípios: enquanto o primeiro deve ser solucionado por meio de subsunção, a colisão de princípios deve ser resolvida por meio de uma ponderação. Cabe aqui explicar o que significa cada método.

Um conflito de regras só pode ser solucionado de duas maneiras: (1) por meio da introdução de uma cláusula de exceção em uma das regras, eliminando, deste modo, o conflito; (2) através da declaração de invalidade de uma das normas. Isso ocorre porque o problema está localizado no plano da validade, e este conceito não é graduável: "ou uma norma jurídica é válida, ou não é". ${ }^{23}$ Regras garantem deveres definitivos, não podendo existir graduações dessa definitividade. Por isso, o conflito entre regras deve ser resolvido por subsunção, aplicando-se integralmente uma determinada regra para o caso. A outra será necessariamente declarada inválida no caso de incompatibilidade total entre as normas e estará fora do ordenamento jurídico.

Já a colisão de princípios é solucionada de forma distinta. Quando dois princípios entram em colisão, um deles tem que ceder perante o outro. Entretanto, isso não significa que exista a declaração de invalidade de um princípio. O que ocorre é que, diante de certas circunstâncias do caso concreto, um princípio precede o outro. A dimensão a ser avaliada

20 Robert Alexy, Teoria dos direitos fundamentais, p. 85, e "Rechtsregeln und Rechtsprinzipien", in: Robert Alexy, Hans-Joachim Koch, Lothar Kuhlen, Helmut Rüßmann (Hsrg.), Elemente einer juristischen Begründungslehre, p. 217.

${ }_{21}$ Cf. Robert Alexy, Teoria dos direitos fundamentais, p. 86 e "Rechtsregeln und Rechtsprinzipien", p. 217. O autor destaca, por exemplo, na Alemanha, a discussão estabelecida a partir da publicação do livro "Grundsatz und Norm" de Jossef Esser em 1956 e, no plano internacional, a discussão a partir de Ronald Dworkin e a publicação do artigo "The Model of Rules" em 1967. Esse artigo foi traduzido para o português (“O modelo de regras I”) e se encontra no livro Levando os direitos a sério. São Paulo: Martins Fontes, 2002. 22 Cf. Robert Alexy, Teoria dos direitos fundamentais, p. 90 e Virgílio Afonso da Silva, "Princípios e regras: mitos e equívocos acerca de uma distinção", Revista Latino-Americana de Estudos Constitucionais 1 (2003), p. 610.

Robert Alexy, Teoria dos direitos fundamentais, p. 92. 
não é de validade, mas sim de peso de cada princípio. ${ }^{24}$ Por isso, esta colisão deve ser resolvida por meio da ponderação. É necessário considerar as variáveis presentes no caso concreto para atribuir pesos a cada direito e avaliar qual deverá prevalecer.

Desse modo, as ponderações entre princípios implicam a determinação fundamentada de uma relação de precedência prima facie entre os princípios em colisão. ${ }^{25}$ A colisão se origina do fato de que diferentes princípios aplicáveis em um caso não podem ser cumpridos ao mesmo tempo de forma plena. Para determinar essa precedência, a avaliação dos pesos dos princípios deverá levar em conta o seguinte raciocínio: "Quanto maior for o grau de não satisfação ou de afetação de um princípio, tanto maior tem que ser a importância de satisfação do outro". ${ }^{26}$ Após sopesá-los, chega-se à relação de precedência condicionada, o que significa que, sob certas condições, um princípio precede o outro: (P1 P P2) C. Sob outras condições, essa precedência pode ser estabelecida inversamente: (P2 P P1) $\mathrm{C}^{\prime 2}{ }^{27}$

Do procedimento de sopesar se estabelece uma relação de preferência entre dois bens em conflito. Em um conceito amplo, poder-se-ia definir o sopesamento como a mera ação de valorar. Trata do enfrentamento ou tensão de dois bens. Outra forma de definir seria como "a ação de considerar imparcialmente os aspectos contrapostos de uma questão ou o equilibro entre o peso de duas coisas". ${ }^{28}$ Em sentido mais estrito e por meio de uma explicação simplificada, o sopesamento seria um método de decisão para solucionar casos de colisão entre princípios, que implica em um raciocínio de preferências ${ }^{29}$ e que se utiliza de uma metáfora de pesos para estabelecer essas preferências. É nesse sentido que se procura estudar o método no trabalho. Em sentido muito estrito, a ponderação corresponderia ao raciocínio entre vantagens-desvantagens ou custos-benefícios dos bens em colisão, ou, em outras palavras, espécie de cálculo de custos e benefícios. ${ }^{30}$

A ponderação pode ainda ser definida por meio de um conceito material ou procedimental. ${ }^{31} \mathrm{O}$ conceito material aponta para o método como um mero cálculo de

$24 \quad$ Robert Alexy, Teoria dos direitos fundamentais, p. 83.

25 Cf. Jan-R. Sieckmann, "Sobre la fundamentación de juicios ponderativos“, p. 161.

26 Este raciocínio seria a "lei da ponderação" ou "lei da sopesamento". Cf. Robert Alexy, "Constitutional Rights, Balacing and Rationality", Ratio Juris 2 (2003), p. 136 e Teoria dos direitos fundamentais, p. 593e Luís Prieto Sanchis, "Neoconstitucionalismo y ponderacíon judicial”, p. 142.

$27 \quad$ Cf. Robert Alexy, Teoria dos direitos fundamentais, p. 97.

28 Luis Prieto Sanchís, "Neoconstitucionalismo y ponderación judicial".

29 Em sentido semelhante, Ana Paula de Barcellos, Ponderação, racionalidade e atividade jurisdicional, p. 23: "a técnica jurídica de solução de conflitos normativos que envolvem valores ou opções políticas em tensão, insuperáveis pelas fórmulas hermenêuticas tradicionais".

$30 \quad$ Cf. Laura Clérico, El examen de proporcionalidad em el derecho constitucional, pp. 255 e ss.

31 Cf. Laura Clérico, El examen de proporcionalidad em el derecho constitucional, pp. 255 e ss. 
interesses sociais, visando um resultado substantivo, no sentido de apontar para uma única resposta correta. Já o procedimental esclarece como deve ser justificado o resultado de ponderação. Nesse caso, o sopesamento corresponderia a um modelo de justificação nas decisões.

A ponderação pode também estar inserida na regra da proporcionalidade, como a terceira sub-regra deste exame. ${ }^{32}$ Porém, neste trabalho, procura-se analisar a ponderação não somente como parte do exame da proporcionalidade, mas também como uma técnica possível de ser aplicada isoladamente. ${ }^{33}$

\subsection{Metodologia}

Neste tópico, pretende-se expor qual será o enfoque dado ao tema e não uma descrição da "forma de trabalhar". Para definir o enfoque metodológico, observou-se a divisão proposta por Robert Alexy, segundo o qual, dentro de um enfoque de caráter dogmático, existem três dimensões a serem seguidas: analítica, empírica e normativa, sendo possível também trabalhar com as três ao mesmo tempo. ${ }^{34}$

No presente trabalho, a abordagem do tema será pluridimensional, com ênfase na dimensão analítica da dogmática, que será utilizada para o exame do debate sobre a racionalidade da ponderação. A dimensão empírica será utilizada paralelamente, com a finalidade de trazer contribuições para a investigação do problema de trabalho. Isso porque se acredita que a observância da aplicação do sopesamento pelos tribunais e da argumentação desenvolvida pelos juízes nos casos difíceis pode proporcionar melhor compreensão do funcionamento da técnica. Por fim, a dimensão normativa será utilizada para fornecer uma tentativa de resposta aos problemas enfrentados na presente pesquisa.

32 Cf. Robert Alexy, "Constitutional Rights, Balancing and Rationality", p. 135. Sobre a proporcionalidade e suas três sub-regras: Virgílio Afonso da Silva, "O proporcional e o razoável", Revista dos Tribunais 798 (2002): 23-50.

33 Ressalva-se que existem atualmente discussões sobre a teoria dos princípios em si e variações de seus conceitos e definições. Porém, neste trabalho, não se pretende entrar em discussões mais profundas da teoria em si, sendo suficientes as explicações feitas neste tópico para o objeto em estudo e desenvolvimento da pesquisa.

34 Cf. Robert Alexy, Teoría de los derechos fundamentales, pp. 29 e ss. 


\subsection{Introdução}

Capítulo 2

Críticas à PONDERAÇÃo

Nesse tópico, pretende-se traçar um panorama geral das críticas da ponderação, a fim de se introduzir o debate do tema. Objeções de vários tipos ao sopesamento são apontadas pelos autores, porém não é possível examiná-las apenas de maneira estanque. As críticas apresentam pontos de conexão entre si.

Alexy, por exemplo, aponta três abordagens principais referentes às críticas ao sopesamento: (1) críticas em relação a sua estrutura; (2) relacionadas à racionalidade; (3) relacionadas à legitimidade do método. Essas objeções encontram-se relacionadas entre si: a legitimidade da ponderação depende de sua racionalidade, em outras palavras, o uso do sopesamento pelo poder judiciário e sua legitimidade depende do desenvolvimento de um método fundamentado, com argumentação coerente e consistente, mostrando-se um modelo não puramente opinativo. ${ }^{35}$ Desse modo, quanto mais racional, mais legítima a prática das ponderações. Já a estrutura é fundamental para definir a sua racionalidade, ${ }^{36}$ visto que é com base nela que se afere a consistência do método.

Em sentido semelhante, Nils Jansen divide as críticas como as referentes (1) à irracionalidade, (2) à impossibilidade de se criar um standard ou construir uma escala no sopesamento e (3) ao caráter não democrático do método, já que, por meio de sua aplicação, o tribunal constitucional exerceria a função do legislador a partir da atividade de uma "interpretação dos direitos fundamentais". 37

Laura Clérico, por sua vez, aponta três principais grupos de críticas do sopesamento: (1) críticas metodológicas; (2) dogmáticas; ou (3) políticas. ${ }^{38}$ As críticas metodológicas se relacionam diretamente ao problema da racionalidade. As dogmáticas dizem respeito à falta de desenvolvimento de uma dogmática da ponderação mais específica, referente à aplicação de cada um dos direitos fundamentais. As políticas consistem na questão do perigo do aumento da amplitude da competência do tribunal constitucional nas decisões envolvendo direitos fundamentais, em oposição à amplitude das competências do legislativo.

35 Sobre racionalidade, justificação e uma argumentação opinativa no direito brasileiro, ver José Rodrigo Rodriguez, "Argumento de autoridade, justiça opinativa e luta pela justificação no direito brasileiro", mimeo.

36 Cf. Robert Alexy, "La formula del peso", in Teoría de la argumentación jurídica, p. 349.

37 Cf. Nils Jansen, "Die Abwägung von Grundrechten”, Der Staat 36 (1997), p. 28.

38 Cf. Laura Clérico, El examen de proporcionalidad en el derecho constitucional, p. 294. 
Essas divisões apontam os principais grupos, nos quais as críticas vão se inserir. Cabe agora, para completar esse panorama geral inicial, apontar as principais correntes de críticas que decorrem desses grupos, para depois analisá-las com maiores detalhes, contextualizando as objeções conforme cada autor.

Uma das principais críticas relacionadas à racionalidade, estrutura e metodologia diz respeito à indeterminação conceitual do sopesamento. A justificação para tal objeção, em linhas gerais, seria a formulação retórica, a não exibição de uma estrutura clara e a falta de critérios objetivos no desenvolvimento e aplicação do método, que possibilitariam controle público da sua decisão. ${ }^{39} \mathrm{O}$ sopesamento teria uma estrutura vazia, que somente com julgamentos subjetivos e ideológicos poderia ser preenchida pelos juízes.

Dessa crítica decorrem também objeções sobre a incomensurabilidade e incomparabilidade na aplicação do sopesamento. Essas críticas dizem respeito à impossibilidade de se estabelecer unidade de medida comum entre os pesos dos direitos ou bens em conflito. Não haveria escala a disposição para determinar o peso dos princípios. ${ }^{40}$ Alguns autores que exploram críticas nesse sentido são Walter Leisner, ${ }^{41}$ Fischer-Lescano e Christensen, ${ }^{42}$ Julian Rivers, ${ }^{43}$ Jacco Bomhoff, ${ }^{44}$ Stravros Tsakyrakis ${ }^{45}$, entre outros. Habermas também aborda - não de forma tão direta quanto os outros autores - essa questão, mas suas considerações são principalmente relacionadas à estrutura e caráter de norma dos valores e suas conseqüências. ${ }^{46}$

Há ainda críticas ao sopesamento como metáfora e indefinição de sua linguagem. $\mathrm{O}$ método, enquanto metáfora de pesos, não funcionaria, pois esta seria muito vaga e incluiria grande variedade de razões e ações humanas. ${ }^{47}$ Desse modo, o sopesamento não deveria ser aceito como método de resolver casos de direitos fundamentais, pois ele fingiria ser um método neutro e esconderia o julgamento moral presente em todas as operações inerentes a ele. Além disso, induziria a idéia de precisão matemática e quantificação precisa de valores

39 Cf. Carlos Bernal Pulido, „Grundrechtsprinzipien in Spanien: Rationalität und Grenzen der Abwägung“, pp. 201-202.

40 Cf. Carlos Bernal Pulido, „Grundrechtsprinzipien in Spanien: Rationalität und Grenzen der Abwägung“, p. 202 e Luis Prieto Sanchís, "Neoconstitucionalismo y ponderación judicial”, pp. 151 e ss.

$41 \quad$ Walter Leisner, Die Abwägungsstaat. Berlin: Dunker \& Humboldt, 1997.

42 Ralph Christensen e Andreas Fischer-Lescano. Das Ganze des Rechts: Vom hierarchischen zum reflexiven Verständnis deutscher und europäischer Grundrechte. Berlin: Duncker \& Humblot, 2007.

43 Julian Rivers, ,Proportionality and Variable Intensity of Review”.

$44 \quad$ Jacco Bomhoff, "Balancing, the Global and the Local: Judicial Balancing as a Problematic Topic in Comparative (Constitutional) Law".

$45 \quad$ Stravros Tsakyrakis, "Proportionality: An assault on human rights?".

46 Cf. Jürgen Habermas, Between Facts and Norms, Cambridge, Mass.: MIT Press, 1998, capítulo 6.

47 Cf. Stravros Tsakyrakis, "Proportionality: An assault on human rights?", p. 469. 
ao se falar na metáfora dos pesos. Haveria aqui uma ilusão referente a uma possível forma mecânica de pesar valores, desconsiderando a complexidade dos direitos em jogo. ${ }^{48}$

A impossibilidade de previsão do resultado do sopesamento também é apresentada como uma objeção, sendo as conseqüências dessa característica a criação de uma “jurisprudência ad hoc", trazendo instabilidade para o ordenamento e problemas para a segurança jurídica. Cada resultado da ponderação seria meramente individual, dependendo das circunstâncias de cada caso e impossibilitando a elaboração de critérios gerais. Por ser um método com significativa indeterminação conceitual, aberto a subjetivismos, qualquer pretensão de universalização das decisões provenientes da aplicação do sopesamento ficaria enfraquecida. ${ }^{49}$

Outro grupo de críticas se relaciona à concepção de Estado no qual o sopesamento se insere, no papel desempenhado pelo judiciário ao sopesar e na legitimidade do sopesamento judicial. Essas objeções aparecem tanto como uma conseqüência da indeterminação da estrutura do sopesamento e irracionalidade do método, citadas anteriormente, como também como objeções independentes. Se o sopesamento se trata, na realidade, de mera opinião pessoal dos juízes sobre preferências, sem qualquer razão que possa justificar a decisão, então haveria déficit de legitimidade do judiciário para realizá-la, já que legitimidade desse poder encontra-se na obrigatoriedade de desenvolvimento de argumentação consistente e coerente, ao contrário do legislativo, eleito democraticamente.

Nesse sentido são feitas críticas à teoria dos princípios e ao sopesamento, relacionadas à própria concepção de direitos fundamentais como princípios, à atividade do tribunal constitucional alemão e a deficiência de legitimidade do tribunal. ${ }^{50}$ Critica-se o conceito de otimização, em primeiro lugar, porque este seria um conceito tão aberto que poderia justificar qualquer intromissão estatal nas liberdades. ${ }^{51}$ Desse modo, a determinação de qual direito deveria ser protegido seria somente uma questão de opinião, obtida por meio do conhecimento das tendências presentes na jurisdição, personalidades dos juízes e atmosfera política que envolve e está presente no tribunal constitucional. Além disso, afirma-se que todos os casos controversos virariam problemas do direito constitucional e haveria o desenvolvimento de um Estado judicial, acarretando violação do

$48 \quad$ Cf. Stravros Tsakyrakis, "Proportionality: An assault on human rights?", p. 474.

49 Nesse sentido, por exemplo, Ernst-Wolfgang Böckenförde, "Grundrechte als Grundsatznormen zur gegenwärtigen Lage der Grundrechtsdogmatik", p. 174 e Karl-Heinz Ladeur, Kritik der Abwägung in der Grundrechtsdogmatik, p. 29.

50 Nesse sentido, por exemplo: Bernhard Schlink, The Dynamics of Constitutional Adjudication“ e „German Constitutional Culture in Transition“.

51 Cf. Bernhard Schlink, „German Constitutional Culture in Transition“, p. 721. 
princípio democrático e da separação de poderes. Por fim, diz-se que o ponto de otimização dos princípios colidentes não poderia ser reconhecido objetivamente por meio do sopesamento. Assim, seria impossível para o tribunal constitucional sopesar de forma objetiva. $^{52}$

Inserem-se nesse grupo de críticas, por exemplo, as considerações de Ladeur $^{53}$, Böckenförde $^{54}$ e Schlink ${ }^{55}$. Böckenförde fala tanto nos problemas da interpretação dos direitos fundamentais via teoria dos valores, como na falta de discricionariedade legislativa acarretada pela tese da otimização. ${ }^{56}$ Para o autor, a teoria não ofereceria um caminho para a solução das colisões entre esses direitos, pois não haveria nem fundamentação racional para os valores e sua ordem como um todo, nem sistema de preferências racional, reconhecível e discutível para a determinação das preferências dos valores e para construção de um sopesamento de valores claro ou evidente. ${ }^{57}$ Schlink, por sua vez, faz críticas de dimensão econômica em um de seus trabalhos, além de afirmar que não é preciso usar do método na resolução de colisões entre direitos fundamentais. Para o autor, a aplicação das duas primeiras sub-regras da proporcionalidade - adequação e necessidade - já propiciaria um juízo técnico e suficiente para resolver esses conflitos, pois essa parte do exame trabalha somente com prognósticos, ou seja, na sua definição, juízos de probabilidade e não avaliações subjetivas. ${ }^{58}$ Essa é também, em certa medida, a posição adotada na jurisprudência canadense em relação à aplicação da regra da proporcionalidade. $^{59}$

Esses são apenas alguns dos pontos principais abordados pelos autores nas suas críticas ao sopesamento. $\mathrm{O}$ que se tentou fazer nesse tópico foi apenas indicar quais são os pontos cruciais de críticas e as vertentes que guiam cada autor, os quais serão analisados detalhadamente nos próximos tópicos.

52 Cf. Carlos Bernal Pulido, „Grundrechtsprinzipien in Spanien: Rationalität und Grenzen der Abwägung ,, p.204.

$53 \quad$ Karl-Heinz Ladeur. Kritik der Abwägung in der Grundrechtsdogmatik.

$54 \quad$ Ernst-Wolfgang Böckenförde, "Grundrechte als Grundsatznormen - zur gegenwärtigen Lage der Grundrechtsdogmatik"e "Grundrechtstheorie und Grundrechtsinterpretation".

$55 \quad$ Bernhard Schlink, "Der Grundsatz der Verhältnismäßigkeit”, "Freiheit durch Eingriffsabwehr Rekonstruktion der klassischen Grundrechtsfunktion”, „The Dynamics of Constitutional Adjudication“, „German Constitutional Culture in Transition“, e Abwägung im Verfassungsrecht.

56 Cf. Ernst-Wolfgang Böckenförde, "Grundrechte als Grundsatznormen: Zur gegenwärtigen Lage der Grundrechtsdogmatik" e "Grundrechtstheorie und Grundrechtsinterpretation".

$57 \quad$ Cf. "Grundrechtstheorie und Grundrechtsinterpretation”, pp. 130 e ss.

58 Cf. Bernhard Schlink, "Der Grundsatz der Verhältnismäßigkeit".

59 Cf. Dieter Grimm, "Proportionality in Canadian and German Constitutional Jurisprudence". O caso que definiu essa perspectiva é o R. v. Oakes ([1986] 1 S.C.R.103 [Oakes]). 


\subsection{A crítica de Habermas: a "jurisprudência de valores" do tribunal constitucional alemão}

A crítica de Habermas se faz com base em uma prática do tribunal constitucional alemão conhecida como "jurisprudência de valores". 60 Essa prática consiste na argumentação baseada em valores para a resolução de colisões entre direitos fundamentais. $\mathrm{O}$ autor desenvolve essas críticas principalmente no capítulo 6 do livro "Direito e democracia", ${ }^{61}$ mas traz importantes conceitos para a crítica no capítulo anterior.

Para o autor, a imanente tensão no direito entre faticidade e validade se manifesta como uma tensão entre o princípio da certeza jurídica e a demanda por uma legítima aplicação do direito, ou seja, a de proferir decisões corretas ou certas. ${ }^{62}$ Habermas diz que tanto a garantia da certeza como da legitimidade devem ser simultaneamente satisfeitas no nível da formação da decisão judicial. ${ }^{63}$ Assim, as cortes devem satisfazer ao mesmo tempo as condições de processo de decisão consistente e de aceitabilidade racional da decisão.

Nesse ponto, é preciso examinar quais são as definições com as quais o autor trabalha em relação à idéia de certeza jurídica e racionalidade. Certeza jurídica consiste na possibilidade da existência de um sistema de precedentes, no sentido de decisões do presente que dialogam com as passadas. Já a demanda de legitimidade requer decisões não apenas consistentes com o tratamento de casos similares ou de acordo com o sistema jurídico existente. Há a necessidade de que as decisões sejam racionalmente fundamentadas, no sentido de que todos os participantes do discurso possam aceitá-las como decisões racionais. ${ }^{64}$ É uma demanda por universalismo das decisões judiciais, o que de certo modo aponta para a preocupação de uma moral construída de forma universal. ${ }^{65}$

Habermas diz, por meio do exame posterior da teoria de Dworkin, que uma migração de conteúdos morais para o direito não significa qualquer moralização imediata

60 Sobre essa discussão, ver também: Virgílio Afonso da Silva e Conrado Hübner Mendes, "Habermas e a jurisdição constitucional", in Marcos Nobre e Ricardo Terra (org.), Direito e democracia. São Paulo: Malheiros, 2008, pp. 204 e ss.

$61 \quad$ Nesse trabalho se utilizará a edição do livro em inglês: Between Facts and Norms: Contributions to a Discourse Theory of Law and Democracy.

62 Cf. Jürgen Habermas, Between Facts and Norms, p. 197.

63 Cf. Jürgen Habermas, Between Facts and Norms, p. 198.

64 Cf. Jürgen Habermas, Between Facts and Norms, p. 198.

65 Em trecho posterior, diz Habermas (p. 222): "The single judge must conceive her constructive interpretation fundamentally as a common undertaking supported by the public communication of citizens". A prática da argumentação demanda que cada participante adote a perspectiva de todos (forma reflexiva de ação comunicativa). Desse modo, a justificativa e racionalidade do autor é basicamente discursiva. 
do direito. ${ }^{66} \mathrm{O}$ conteúdo moral dos direitos constitucionais e princípios é explicitado pelo fato de que normas básicas, tanto de direito como de moral, fundamentadas no mesmo princípio do discurso, substantivamente intersectam. ${ }^{67}$

A partir desse ponto, Habermas define regras e princípios, conceito que será fundamental em sua crítica posterior ao sopesamento. Para ele, tanto regras quanto princípios são normas que demandam ser deontologicamente válidas; elas não possuem uma estrutura teleológica, ou seja, não são guiadas apenas para a realização de um fim. Por isso, princípios não deveriam ser entendidos como mandamentos de otimização, pois essa definição acabaria com o caráter deontológico da norma. ${ }^{68}$

Esse é o conceito chave da objeção do autor. A decisão judicial não pode ser guiada apenas com a perspectiva de se atingir o fim da maneira mais efetiva possível. O mais importante é a argumentação desempenhada pelo juiz no processo de decisão. É desse processo que provém a legitimidade do poder judiciário. Os argumentos são as razões proferidas no discurso, que satisfazem a exigência de validade levantada com atos de fala regulatórios; elas motivam racionalmente a argumentação, para aceitar opiniões descritivas ou normativas como válidas. Assim, as condições do discurso racional para Habermas consistem basicamente em argumentos motivados e na participação igual e universal dos interlocutores (igual acesso ao debate, liberdade de escolha, não coerção, entre outros elementos). Há a idéia inerente de processo de $\operatorname{argumentação~}^{69}$ e de uma aceitação racional embasada em razões.

A crítica do autor é direcionada, como foi dito anteriormente, à "jurisprudência de valores" da corte constitucional alemã e à falta de clareza dessas decisões. Para ele, direitos não precisam ser assimilados como valores. Isso porque os valores não têm uma prioridade inerente e incondicional em relação a outros valores. A operação de sopesar, nesse sentido, pode transformar a interpretação do direito em mero "negócio de realizar valores", somente de acordo com a forma concreta e casos específicos, sem qualquer pretensão de universalização e fundamentação na argumentação.

Dessa maneira, o problema para Habermas é que os valores possuem caráter teleológico, ou seja, somente dirigido a obtenção de um fim e não ao desenvolvimento da

\footnotetext{
66 Cf. Jürgen Habermas, Between Facts and Norms, p. 206.

67 Cf. Jürgen Habermas, Between Facts and Norms, p. 206.

68 Cf. Jürgen Habermas, Between Facts and Norms, p. 208.

69 Segundo o autor: "The argumentative process of the cooperative search for truth ideally closes the rationality gap between, on the one hand, the individual substantial reasons set out in fundamentally incomplete sequences of argument that are at most plausible and, on the other, the unconditionally of the claim to the "single right" answer", p. 228.
} 
argumentação fundamentada, o que legitima a decisão judicial. Os valores representam a formação de normas casuísticas, e não "normas válidas de ação que obrigam seus destinatários igualmente e sem exceção para satisfazer expectativas de comportamento generalizadas", $^{70}$ Valores representam, então, apenas preferências divididas intersubjetivamente. Por outro lado, as normas, em virtude de seu caráter deontológico, podem demandar ser universalmente vinculantes e não somente preferidas.

Valores estabelecem relações de preferência, dizendo que alguns bens são melhores que outros, em coletividades específicas. Normas de ação aparecem com uma demanda de validade binária e são válidas ou inválidas. Valores são sentenças avaliativas, podem ser decididas em maior ou menor grau. Por isso, uma das principais diferenças entre esses dois tipos de normas é em relação ao critério de coerência que o sistema de normas e de valores deve satisfazer. ${ }^{71}$ Uma norma regula um assunto no igual interesse de todos. Já os valores entram em uma determinada configuração com outros valores, a fim de se constituir uma ordem simbólica que expressa a identidade e forma de vida de uma comunidade jurídica em particular. ${ }^{72}$

Com essa transformação de conceito de norma para valores, poder-se-ia dizer que os direitos fundamentais têm sido mascarados pela teleologia, considerando o fato de que normas e valores desempenham papéis diferentes na lógica argumentativa em contextos de justificação. $^{73}$ Além disso, a utilização de normas como valores na jurisprudência transforma o tribunal em uma "instância autoritária", pois não seria aqui preenchido o requisito da legitimidade do judiciário por meio de argumentação coerente e consistente. Nesse momento aparecem também considerações a respeito do papel da corte constitucional, das atividades e competências do legislativo e separação de poderes.

A preocupação de Habermas consiste no fato de que direitos enquanto valores obtêm todos o mesmo nível de prioridade. Nesse caso, os argumentos de ordem política ficam no mesmo nível dos direitos fundamentais no discurso jurídico, e isso pode gerar proteção menor dos direitos individuais em relação a interesses coletivos. ${ }^{74}$ Desse argumento surge a crítica da irracionalidade, pois não haveria critérios racionais no sopesamento de valores, visto que ele é feito caso a caso. O método acabaria sendo

\footnotetext{
70 Cf. Jürgen Habermas, Between Facts and Norms, p. 254.

Cf. Jürgen Habermas, Between Facts and Norms, p. 254.

Cf. Jürgen Habermas, Between Facts and Norms, p. 256.

Cf. Jürgen Habermas, Between Facts and Norms, p. 257.

Cf. Jürgen Habermas, Between Facts and Norms, p. 259.
} 
aplicado de forma arbitrária e irrefletida, de acordo com costumes. ${ }^{75}$ Por fim, afirma que não há unidade clara para medir os valores e o perigo de regras irracionais surgirem nas decisões cresce.

Para Habermas, as normas são submetidas a uma provisão de coerência, que certifica que todas as normas se encaixam juntas em um sistema unificado, desenhado para admitir exatamente uma solução correta em cada caso. Isso não ocorreria no caso dos valores, que possuiriam caráter teleológico de um bem desejado, sendo alcançado sob circunstância do caso concreto, medido por meio de grau e de acordo com o horizonte de preferências. $^{76}$

Apesar das críticas, isso não quer dizer que o autor negue a possibilidade de decidir racionalmente questões constitucionais em geral. A interpretação dos direitos e princípios é, para ele, como a das normas ordinárias. E conceitua que a aplicação de princípios não deve gerar espaços de racionalidade maiores dos que já existem com a aplicação de normas. $^{77}$

Acredita-se, no entanto, que o problema consiste em supor que as normas de valor perderiam a exigência de fundamentação. Os princípios não possuem somente caráter teleológico, que levaria a uma argumentação superficial no raciocínio do autor, apenas dirigida à efetivação do fim. Há a mesma preocupação de fundamentação, a diferença é que, neste âmbito, é necessário desenvolvê-la na dimensão do peso e não na dimensão da validade, substituindo-se a ordem binária do válido e inválido para uma ordem gradual. Entretanto, a natureza das normas como princípios não retira os requisitos de legitimidade gerais do judiciário. É claro que uma ordem gradual abre maior espaço para a discricionariedade de decisão do juiz. Contudo, isso não acarreta diretamente uma decisão arbitrária, a falta de desenvolvimento de argumentação ou a não exigência de preenchimento dos requisitos de coerência e consistência.

Cabe ver, aqui, até que ponto o estabelecimento de uma ordem gradual permite mais ou menos o aparecimento de critérios racionais na argumentação para justificar a tomada de decisões dos juízes. Como observa Sieckmann, o problema da ponderação é se o resultado ponderativo pode ser determinado de forma racional, ou seja, se as proposições

\footnotetext{
75 Cf. Jürgen Habermas, Between Facts and Norms, p. 259.

76 Cf. Jürgen Habermas, Between Facts and Norms, p. 261. Habermas complementa o raciocínio: "what is the best for us at a given point does not eo ipso coincide with what is equally good for all".

77 Além desse debate, é tratada no capítulo 6 a questão de qual seria o papel desempenhado pelo tribunal constitucional, que é, para o autor, o de "guardião da democracia deliberativa". Essa questão em específico, sob o ponto de vista de Habermas e seus debatedores, não será abordada aqui.
} 
normativas que sustentam o resultado do sopesamento podem ser fundamentadas. ${ }^{78}$ Esse é um ponto que será analisado mais atentamente na segunda etapa do trabalho.

\subsection{Schlink, direitos subjetivos e princípios objetivos no tribunal constitucional alemão}

É interessante observar que outro autor crítico do sopesamento se opõe a caracterização de Habermas a respeito da "jurisprudência de valores" estabelecida pelo tribunal constitucional alemão, a partir da década de 1950. Schlink acredita que a orientação por meio de valores da corte trata-se de um mito, pois não foi uma construção com ambição de desenvolver conceitos filosóficos. ${ }^{79}$ Foi, na realidade, apenas um conceito guarda-chuva necessário à época, sob o qual se poderiam vincular direitos fundamentais nas relações entre particulares, assim como contra instituições e procedimentos governamentais, mudando a concepção tradicional de direitos fundamentais como direitos de defesa dos indivíduos frente ao Estado.

O autor comenta que um juiz do tribunal constitucional na época afirmou que a corte não tinha interesse ou idéia filosófica na base da sua primeira decisão, mas que só precisava de um conceito novo que permitisse mudança na jurisprudência. ${ }^{80}$ Por isso, para Schlink, a diferenciação de Habermas de princípios como valores e como normas perde o sentido: "princípios como normas não são opostos a princípios como valores". ${ }^{81}$ Princípios são normas coerentes no todo e somente conflitam em situações específicas. Essa certa flexibilidade não retira a sua validade e vinculação, mas permite que o tribunal constitucional introduza novas interpretações de direitos fundamentais.

A constatação que Schlink extrai dessas afirmações é que as mudanças na interpretação dos direitos fundamentais nas últimas quatro décadas no tribunal alemão são devidas mais à existência de uma corte com amplos poderes do que com desenvolvimentos teóricos em si, visto que não houve preocupação em desenvolver teorias, mas apenas em resolver casos concretos. ${ }^{82}$ Parece-me, então, conforme afirmado pelo autor, que se trata mais de um problema na atuação e papel desempenhado pelo tribunal constitucional, da

78 Cf. Jan-R. Sieckmann, "Ponderación autónoma", p. 143. O autor, para aferir isso, lista "três aspectos de objetividade" para o desenvolvimento da ponderação.

79 Cf. Bernhard Schlink, „The Dynamics of Constitutional Adjudication”, p. 1234.

80 A primeira decisão do tribunal constitucional alemão que apresenta os conceitos em jogo é o caso Lüth, de 1958 (BVerfGE 7, 198).

81 Bernhard Schlink, ,The Dynamics of Constitutional Adjudication”, p. 1234.

82 Cf. Bernhard Schlink, „The Dynamics of Constitutional Adjudication”, p. 1235. 
revisão judicial, do que somente metodológico. Por isso, para Schlink, o que se apresenta como ponto controverso é, na realidade, a questão dos poderes amplos do tribunal constitucional e a das inclinações políticas de seus diferentes juízes, que se manifestam inevitavelmente nas decisões. O autor critica as abordagens genéricas e diz que não há revisão judicial independente de um contexto histórico. ${ }^{83}$

O ponto de vista do autor fica mais claro em outro texto. ${ }^{84}$ Nele, Schlink fala da cultura constitucional alemã em transição, da mudança do papel, atividades e diálogos entre tribunal constitucional e a literatura jurídica. A objeção central encontra-se no conceito desenvolvido pela jurisprudência de princípios objetivos, em oposição a direitos subjetivos, e na teoria dos princípios no geral. O conceito de "princípios objetivos" significa que os direitos fundamentais são máximas, ordenadas de acordo com as relações sociais e as relações entre Estado e sociedade. ${ }^{85} \mathrm{O}$ conceito de direitos fundamentais como princípios estaria relacionado com a concepção de ordem objetiva.

Schlink aponta que o tribunal constitucional alemão adotou essa concepção de princípios objetivos devido a quatro questões controversas, que promoveram o desenvolvimento do conceito: ${ }^{86}$ (1) a vinculação dos direitos fundamentais nas relações entre particulares; (2) a relevância dos direitos fundamentais para a formação das instituições e procedimentos governamentais; (3) o papel do governo na proteção desses direitos, tendo a obrigação de desempenhar papel ativo na proteção das liberdades, contra a intromissão de particulares; e, por fim, (4) a pergunta se os direitos fundamentais protegeriam somente contra intromissões governamentais ou se também dão direito a reclamações por serviços governamentais.

O problema seria então o fato de que "direitos fundamentais estão abertos às interpretações mais variadas quando são vistos como princípios". ${ }^{87} \mathrm{O}$ núcleo da crítica é o conceito de otimização da teoria dos princípios, pois, segundo o autor, "a regra da otimização é um conceito tão aberto que pode justificar qualquer intromissão estatal nas liberdades". ${ }^{88}$ Não se trata apenas de uma mera questão de aplicar uma metodologia jurídica por meio desses conceitos de direitos fundamentais como princípios. Para o autor, a determinação de qual direito, nos casos de colisão, deve ser protegido na decisão do tribunal constitucional é algo metodologicamente impossível de previsão. Somente pode

83 Cf. Bernhard Schlink, „The Dynamics of Constitutional Adjudication”, p. 1237.

84 Cf. Bernhard Schlink, „German Constitutional Culture in Transition“.

85 Cf. Bernhard Schlink, „German Constitutional Culture in Transition“, p. 713.

86 Cf. Bernhard Schlink, „German Constitutional Culture in Transition“, pp. 718-721.

87 Bernhard Schlink, „German Constitutional Culture in Transition“, p. 721.

88 Bernhard Schlink, ,German Constitutional Culture in Transition“, p. 721. 
ser uma questão de opinião, que é obtida por meio do conhecimento das tendências presentes na jurisdição, personalidades dos juízes e atmosfera política que envolve e está presente no tribunal. Além disso, essa perda de certeza acarretada pela adoção do conceito de princípios objetivos é desnecessária. Para Schlink, muitos dos casos que adotam esse conceito poderiam ser também resolvidos por um entendimento estrito de direitos fundamentais como direitos subjetivos. ${ }^{89}$

O problema apresentado pelo autor tem como conseqüência as freqüentes críticas relacionadas à legitimidade do método no âmbito judicial ou políticas. O conceito dos direitos como princípios permitiria a reconstrução de todo problema social e político como uma questão de direitos fundamentais. Há, a partir desse ponto, mudança do papel do tribunal constitucional, transformando-se em um fórum adicional ao legislativo para o tratamento desses problemas. O tribunal torna-se ativista, com metodologia jurídica menos consistente ou menos preocupado no desenvolvimento de um método. Desse modo, a jurisprudência acaba se tornando mera análise caso a caso e não um todo coerente.

Como princípios objetivos, os direitos fundamentais deixaram a definição tradicional de direitos de defesa e passaram a representar também um dever de proteção do Estado em relação aos indivíduos nas suas relações entre si. Nessa perspectiva, os direitos “ofereceram mais substância para criticar e controlar o legislador, para instruí-lo e apontar certas direções". ${ }^{90}$ Soma-se a isso a sensação de descrédito em relação ao legislativo, o que acaba motivando o tribunal constitucional a adotar papel mais ativista do que sua atividade tradicional de controle de constitucionalidade. ${ }^{91}$ A crítica maior, nesse sentido, é a usurpação pelo tribunal de competências tipicamente legislativas.

É interessante observar que essa idéia de "descrédito do legislativo" e ineficiência do legislativo na aprovação de leis é usada também no cenário nacional recente de forma constante, legitimando uma atuação mais ampla do STF em casos polêmicos, principalmente em casos de reformas no sistema eleitoral. ${ }^{92}$ Está ainda, do mesmo modo,

89 Cf. Bernhard Schlink, „German Constitutional Culture in Transition“, p. 729.

90 Bernhard Schlink, ,German Constitutional Culture in Transition“, p. 723.

91 "Dirty politics suffered from a deficit of legitimacy, while clean law and its representative, the Bundesverfassungsgericht, enjoyed a legitimacy "surplus." These were the conditions that invited and demanded that the Bundesverfassungsgericht take on an activist role". Bernhard Schlink, "German Constitutional Culture in Transition“, p. 725.

92 O STF enfrentou, nos últimos anos, questões importantes sobre reforma política, como cláusula de barreira (ADI 1351), verticalização das coligações partidárias (ADI 3685), e fidelidade partidária (MS 26.603), por exemplo. A última grande decisão polêmica nesse âmbito foi o julgamento, ainda que não por via concentrada, da chamada "Lei da Ficha Limpa" (RE 630.147). O Ministro Gilmar Mendes, que foi presidente do STF no período de 2008-2010, disse em entrevista em novembro de 2009: "Supremo tem muitas restrições às mudanças no processo eleitoral". 
implícita nesse debate a falta de confiança da sociedade no poder legislativo e a posição do tribunal como o "guardião da constituição" capaz de "moralizar" as questões controvertidas na sociedade.

\subsection{Aspectos das teorias de direitos fundamentais e críticas à teoria dos princípios}

O centro da crítica do sopesamento também pode estar na base do desenvolvimento das teorias de direitos fundamentais. Esse é o ponto de vista de Böckenförde, que faz críticas basicamente de duas ordens: decorrente da teoria de direitos fundamentais que se segue para desenvolver uma interpretação desses direitos e em relação ao conceito de direitos fundamentais como princípios.

A primeira formulação de crítica é analisada por meio do pretexto da necessidade de se determinar uma teoria dos direitos fundamentais, para se fazer posteriormente a interpretação desses direitos. ${ }^{93} \mathrm{O}$ ponto de partida destacado pelo autor constitui preocupação importante, pois se trata de esclarecer os pressupostos teóricos, com base nos quais a interpretação será feita, o que pode gerar maior clareza na argumentação do operador do direito. Conforme destaca o autor, uma teoria dos direitos fundamentais corresponde à compreensão sistematicamente orientada sobre o caráter geral, a direção normativa do objetivo e o alcance do conteúdo dos direitos fundamentais. ${ }^{94}$ A questão aqui seria, então, qual teoria precede a interpretação de uma delimitação de direitos fundamentais.

São apresentadas na análise cinco principais teorias dos direitos fundamentais: (1) a teoria liberal; (2) a teoria institucional; (3) a teoria dos valores dos direitos fundamentais; (4) a teoria democrática funcional dos direitos fundamentais; e (5) a teoria do Estado Social. ${ }^{95}$ A teoria liberal é a clássica, a qual aparentemente o autor se afilia. Nela há a conceito de direitos de defesa do cidadão frente ao Estado e a não intervenção estatal na esfera privada. Trata-se do agente estatal como único responsável pelas restrições e intervenções nos direitos fundamentais.

http://ultimainstancia.uol.com.br/noticia/INTERFERENCIA+DO+JUDICIARIO+NO+LEGISLATIVO+E+L EGITIMA+AFIRMA+GILMAR+MENDES_65712.shtml. Acesso: 9.09.2010. Além disso, no geral, o Tribunal Superior Eleitoral (TSE) vem sendo muito criticado por sua atuação.

93 A crítica está presente no artigo da Neue Juristische Wochenshrift (NJW), escrito em 1974. O texto foi também publicado como o capítulo "Grundrechtstheorie und Grundrechtsinterpretation" do livro Staat, Verfassung, Demokratie. Frankfurt am Main: Suhrkamp, 1991.

$94 \quad$ Cf. Ernst-Wolfgang Böckenförde, "Grundrechtstheorie und Grundrechtsinterpretation”, p. 118.

95 Cf. Ernst-Wolfgang Böckenförde, "Grundrechtstheorie und Grundrechtsinterpretation”, p. 118. 
$\mathrm{Na}$ teoria institucional, por sua vez, os direitos fundamentais têm o caráter de princípios objetivos no ordenamento, não se tratam somente de direitos de defesa do indivíduo. Haveria nesse caso, então, maior discricionariedade para a normatização legislativa e configuração do âmbito de proteção desses direitos. A chave nessa teoria é que pode haver limitações de liberdade orientadas especificamente para a realização de determinados objetivos institucionais. ${ }^{96}$

$\mathrm{Na}$ teoria dos valores dos direitos fundamentais se encontra, de certa forma, a base da crítica de Böckenförde à racionalidade do sopesamento. Em linhas gerais, nessa teoria os direitos têm caráter de normas objetivas, não apresentando somente uma demanda subjetiva. Desse conceito aponta o autor algumas conseqüências. Ele diz que, nessa concepção, a interpretação dos direitos fundamentais torna-se, em primeiro lugar, uma questão pura do tratamento das ciências humanas e emancipada do método jurídico, ou seja, a interpretação não seria aqui guiada por um método. A determinação do conteúdo dos direitos se tornaria somente o que de forma intuitiva parece ser para as ciências humanas, o que, segundo Böckenförde, é averiguável apenas por meio da correlação com a consciência dos valores intelectuais-culturais no tempo. ${ }^{97}$ Seria, portanto, uma determinação extremamente aberta e haveria grande relativização dos direitos fundamentais.

Na verdade, diz o autor, a teoria dos valores não oferece um caminho para a solução das colisões entre os direitos fundamentais. Isso porque não há nem uma fundamentação racional para os valores e sua ordem como um todo, nem um sistema de preferências racional, reconhecível e discutível para a determinação das preferências dos valores e para construção de um sopesamento de valores claro ou evidente. ${ }^{98}$ Recorrer a uma ordem de valores ou a sopesamento não apresenta qualquer fundamentação. Desse modo, a crítica de Böckenförde é que, na prática, trata-se apenas de decisionismo interpretativo. A fundamentação dada muito mais esconde a decisão da colisão entre direitos e do sopesamento, por meio do qual há aparência de racionalidade.

Böckenförde também examina a teoria democrática-funcional dos direitos fundamentais. Nessa teoria, a garantia dos direitos no âmbito das liberdades acontece primeiramente para possibilitar a proteção do processo democrático. Há inerente a preocupação com o interesse público. Por isso, a garantia das liberdades é um meio para a

96 Cf. Ernst-Wolfgang Böckenförde, "Grundrechtstheorie und Grundrechtsinterpretation", p. 124.
97 Cf. Ernst-Wolfgang Böckenförde, "Grundrechtstheorie und Grundrechtsinterpretation", pp. 129 e ss.
98 Cf. Ernst-Wolfgang Böckenförde, "Grundrechtstheorie und Grundrechtsinterpretation", pp. 130 e ss. 
facilitação e a segurança do processo político democrático. O problema é quais critérios serão utilizados pelo Estado para restringir liberdades e assegurar o processo político, o que pode, inclusive, levar ao mero decisionismo. ${ }^{99}$

A última teoria apresentada pelo autor é a do Estado Social. A teoria é pautada pelo dever do Estado em efetivar os direitos. Está em discussão a concretização dos direitos fundamentais, dependente do orçamento estatal e os meios de financiamento estatais disponíveis para isso. O problema aqui, para Böckenförde, é que os direitos são, na sua dimensão social, reduzidos a simples ordens da Constituição. ${ }^{100}$ Em outras palavras, tratase das dificuldades da efetivação dos direitos sociais.

Desse exame das cinco teorias enumeradas, o autor observa que teorias de direitos fundamentais são mais que expressões de concepções de Estado ou idéias sobre a relação entre comunidade e Estado. Encontra-se, por trás dessas teorias, uma idéia específica de constituição. Há, por isso, grande relevância em se esclarecer as implicações da aplicação de determinada teoria para a interpretação dos direitos, visto que pode até mudar a concepção da constituição. É justamente esse o ponto principal de crítica de Böckenförde em outro texto. Para ele, a teoria dos princípios estaria mudando a constituição e a separação de poderes e transformando o Estado em um estado judicial. ${ }^{101}$

\subsection{O Estado judicial do sopesamento}

Para a objeção de um "Estado judicial", haveria, no âmbito da aplicação dos direitos fundamentais como princípios, hipertrofia desses direitos e a atuação do tribunal constitucional como legislador complementar ou supercontrolador dos outros poderes. A intensidade e área de irradiação dos efeitos dos direitos fundamentais como princípios seria indeterminada, causando problemas para a atuação dos tribunais, especialmente no âmbito do controle de constitucionalidade. A indeterminação acarretaria julgamentos e conceitos abertos, e a resolução de conflitos somente a partir de casos concretos e sem pretensão de universalização. Na concepção de deveres de proteção, a resolução de conflitos entre os direitos seria também apenas caso a caso, pois questões como conteúdo e área de proteção

\footnotetext{
99 Cf. Ernst-Wolfgang Böckenförde, "Grundrechtstheorie und Grundrechtsinterpretation”, pp. 133 e ss. 100 Cf. Ernst-Wolfgang Böckenförde, "Grundrechtstheorie und Grundrechtsinterpretation”, pp. 136 e ss.

101 Cf. Ernst-Wolfgang Böckenförde, "Grundrechte als Grundsatznormen - zur gegenwärtigen Lage der Grundrechtsdogmatik", pp. 159 e ss.
} 
dos direitos fundamentais somente poderiam ser respondidas por meio da concretização desses direitos. ${ }^{102}$

Nesse sentido, a interpretação e a aplicação dos direitos fundamentais enquanto princípios mudam constantemente, conforme o caso concreto. A incerteza vincula-se à própria concepção de direitos. Além disso, o processo de concretização teria uma amplitude maior que uma interpretação usual. Esse processo representaria interpretação muito além do que mera criação do direito nesse âmbito interpretativo. ${ }^{103}$

O resultado desse processo seria a mudança da relação entre legislador e controle de constitucionalidade, a aproximação do tribunal constitucional e do parlamento, e o enfraquecimento do legislativo. Em resumo, haveria mudança na classificação dos poderes e transferência das atividades específicas entre eles. ${ }^{104}$ Para o autor, isso aponta para transição de um estado com base no legislativo para um estado judicial. O tribunal constitucional acabaria se tornando órgão mais fortemente político na separação de poderes e a pergunta que se segue da constatação seria qual sua legitimidade democrática para tanto.

É possível observar que a discussão se volta principalmente para o âmbito das objeções relacionadas à legitimidade democrática do tribunal e políticas. Böckenförde questiona os limites da atuação do tribunal constitucional e diz que há graves problemas com o método possível de ser empregado nas suas decisões. Isso porque esse método é puramente subjetivo, sem unidade de medida disponível e sem possibilidade de controle objetivo. ${ }^{105}$ A crítica é da atividade judicial como um todo, mas acaba sendo potencializada em relação ao sopesamento, devido às considerações referentes ao conceito de direitos fundamentais como princípios.

Assim, reafirma o autor a suposta mudança na concepção de separação de poderes com a ordem objetiva e expansão da validade dos direitos fundamentais, tomando lugar um "regime de controle de constitucionalidade". Se se quiser evitar esse cenário, ou seja, rejeitar uma modificação na estrutura da constituição em favor de um estado judicial, então

102 Cf. Ernst-Wolfgang Böckenförde, "Grundrechte als Grundsatznormen - zur gegenwärtigen Lage der Grundrechtsdogmatik", p. 174.

103 Cf. Ernst-Wolfgang Böckenförde, „Grundrechte als Grundsatznormen - zur gegenwärtigen Lage der Grundrechtsdogmatik”, p. 186. Toda interpretação implica em criação, mas, segundo Böckenförde, nesse caso, a interpretação iria além dos limites criativos possíveis nesse âmbito.

104 Cf. Ernst-Wolfgang Böckenförde, "Grundrechte als Grundsatznormen - zur gegenwärtigen Lage der Grundrechtsdogmatik", p. 189.

105 Cf. Ernst-Wolfgang Böckenförde, "Grundrechte als Grundsatznormen - zur gegenwärtigen Lage der Grundrechtsdogmatik", p. 192. 
a única concepção possível de direitos fundamentais seria a de direitos subjetivos de liberdades públicas perante o Estado e não como princípios. ${ }^{106}$

\subsection{Sopesamento e acumulação de conhecimentos nas decisões}

Outro autor que trata em sua crítica de um "Estado do sopesamento" é Karl-Heinz Ladeur. Ele diz que a jurisprudência e a dogmática dos direitos fundamentais têm sido dominadas de forma tão intensa por uma "teoria do sopesamento", que nem os pressupostos dessa teoria nem alternativas dogmáticas a ela puderam ganhar contornos no debate jurídico. ${ }^{107} \mathrm{O}$ que ocorre na realidade é a aplicação do método sem maiores questionamentos. Além disso, da forma como o sopesamento é utilizado com frequiência atualmente, há a sensação de que o modelo teria resolvido todos os problemas de coordenação das diferentes dimensões dos direitos fundamentais.

Do mesmo modo que Böckenförde, a objeção de Ladeur vai no sentido de que o sopesamento deixa o legislativo sem discricionariedade e que isso é uma questão política inevitável. ${ }^{108}$ Um enfoque adicional deste autor sobre o tema diz respeito à questão do Estado realizar sopesamentos no âmbito privado. Para ele haveria, além do apontado por Böckenförde, a "hipertrofia de um Estado intervencionista". ${ }^{109}$ Desse modo, o problema para Ladeur aparenta ser muito mais o papel do Estado, principalmente o desempenhado naquele âmbito. $\mathrm{O}$ agente estatal não poderia vincular sua racionalidade própria entre indivíduos, mas deveria existir uma "racionalidade relacional heterogênea", que corresponderia à cooperação prática entre indivíduos e organizações privadas, no intuito de trazer um conhecimento comum à validade.

Isso porque, para o autor, a teoria do sopesamento se sustentaria em uma "falácia normativa", visto que o método invocaria somente objetivos e valores, mas não poderia esclarecer exatamente como, em casos complexos de decisão, poderiam ser acumulados os conhecimentos necessários para a aplicação do sopesamento. ${ }^{110}$ Em outras palavras, tratase da questão de como seria possível acumular e adquirir conhecimentos para casos de sopesamento. Nesses casos, para Ladeur, todas as orientações do ordenamento jurídico estariam contidas na concepção de otimização de princípios, o que se mostraria

106 Cf. Ernst-Wolfgang Böckenförde, "Grundrechte als Grundsatznormen - zur gegenwärtigen Lage der Grundrechtsdogmatik", pp. 193-194.

107 Cf. Karl-Heinz Ladeur, Kritik der Abwägung in der Grundrechtsdogmatik, p. 12.

108 Cf. Karl-Heinz Ladeur, Kritik der Abwägung in der Grundrechtsdogmatik, pp. 13-14.

109 Cf. Karl-Heinz Ladeur, Kritik der Abwägung in der Grundrechtsdogmatik, p. 15.

110 Cf. Karl-Heinz Ladeur, Kritik der Abwägung in der Grundrechtsdogmatik, p. 29. 
insatisfatório. O sopesamento, então, não poderia contribuir para a formação de regras gerais, mas somente orientar decisões individuais. Não seria possível a acumulação de conhecimentos via a operação, cada novo sopesamento conduziria a um raciocínio novo e meramente individual.

\subsection{Proporcionalidade e a dispensabilidade de se sopesar direitos no exame}

Em artigo mais recente, Schlink apresenta outro grupo de críticas diretamente relacionadas ao exame da proporcionalidade. ${ }^{111}$ Segundo o autor, a proporcionalidade em sentido estrito - o sopesamento - seria uma etapa dispensável do exame. Em linhas gerais, na sua concepção, poder-se-ia realizar o controle da proporcionalidade por meio das duas primeiras sub-regras. Além disso, a ponderação não estaria inserida no exame da necessidade, que representaria apenas um prognóstico e não uma valoração, típica do raciocínio da ponderação.

Para analisar as críticas com maiores detalhes, mostra-se importante, nesse tópico, fazer primeiramente algumas considerações sobre a proporcionalidade. Este exame constitui regra de interpretação e aplicação do direito, empregada especificamente nos casos em que ato estatal, destinado a promover a realização de direito fundamental ou de interesse coletivo, implica a restrição de outro ou outros direitos fundamentais. ${ }^{112}$ Ele é composto por três sub-regras: (1) adequação; (2) necessidade; (3) proporcionalidade em sentido estrito.

A sub-regra da adequação diz que o primeiro exame a se fazer para verificar a proporcionalidade de uma medida restritiva de direitos fundamentais é analisar se esta fomenta a realização do fim almejado. Seria um exame da adequação do meio em relação ao fim, e este seria positivo se a medida fosse apta a, no mínimo, fomentar o objetivo perseguido.

A sub-regra da necessidade, por sua vez, diz que uma medida só será necessária se não existir outra medida tão eficiente quanto à questionada para fomentar o objetivo pretendido e, ao mesmo tempo, que esta outra restrinja menos o direito fundamental do que a primeira. Trata-se de um teste comparativo de medidas, sendo necessário analisá-las sob dois aspectos: (1) eficiência na promoção do objetivo almejado; (2) grau de restrição do

\footnotetext{
111 Cf. Bernhard Schlink, "Der Grundsatz der Verhältnismäßigkeit", in: Festschrift 50 Jahre Bundesverfassungsgericht, Bd. 2, 2001.

112 Cf. Virgílio Afonso da Silva, "O proporcional e o razoável", Revista dos Tribunais 798 (2002), p. 
direito fundamental. Se a medida M2 não for tão eficiente quanto M1, não importa qual é grau de restrição de M2. Em primeiro lugar, as medidas precisam ser de igual eficiência, para depois se comparar as restrições de cada uma.

Por fim, a proporcionalidade em sentido estrito corresponde ao sopesamento. Ressalta-se que os testes se relacionam de maneira que somente será possível analisar o próximo se a medida restritiva de direitos fundamentais tiver passado no teste anterior. Caso contrário representa o fim do exame e a medida em questão revela-se desproporcional.

O ponto central aqui corresponde à questão se um raciocínio de sopesamento já estaria ou não contido no exame da necessidade na proporcionalidade. Schlink se pergunta, nesse sentido, como deveriam ser realizadas as avaliações sobre o objetivo a ser fomentado e medidas disponíveis. Para analisar essa controvérsia, a diferença entre prognóstico e avaliação é fundamental na opinião do autor. ${ }^{113}$

Prognósticos seriam, na sua definição, afirmações sobre a realidade no futuro. Já avaliações seriam decisões, nas quais uma de duas medidas é preferida. Avaliações não aparecem como verdadeiras ou falsas, mas os prognósticos, sim. Os dois podem ser otimizados. A maior diferença, para o autor, é que por meio do prognóstico seria possível obter uma verdade objetiva, enquanto que por meio da avaliação haveria apenas decisões subjetivas. Esse raciocínio decorre da constatação de que as duas operações provêm de racionalidades distintas: na avaliação é a racionalidade da política e no prognóstico é a da busca da verdade e a procura da ciência. ${ }^{114}$ Parece-me que o autor adere a essa opinião por considerar a necessidade como um exame de questões meramente fáticas, um exame técnico, sem implicações políticas, ${ }^{115}$ sendo possível provar se são ou não verdadeiras por meio de considerações científicas, diferentemente do sopesamento, que se trata de uma avaliação de aspectos jurídicos. Nesse sentido, o raciocínio interpretativo despendido nessa etapa não pode ser construído objetivamente, mas subjetivamente.

Para Schlink, a determinação que um meio não é necessário porque outro meio menos gravoso existe se encontra como um fato ou realidade, não em uma própria avaliação a ser encontrada. ${ }^{116}$ Além disso, como a necessidade trabalha com prognósticos,

\footnotetext{
113 Cf. Bernhard Schlink, "Der Grundsatz der Verhältnismäßigkeit”, pp. 455 e ss.

114 Cf. Bernhard Schlink, "Der Grundsatz der Verhältnismäßigkeit”, pp. 455 e ss.

115 Cf. Bernhard Schlink, Abwägung im Verfassungsrecht, pp. 187 e ss.

116 Cf. Bernhard Schlink, "Der Grundsatz der Verhältnismäßigkeit”, p. 456.
} 
trata-se de um juízo de probabilidade e não avaliações subjetivas nessa parte do exame. ${ }^{117}$ A limitação da necessidade a prognósticos, segundo o autor, é uma obrigação substancial do Estado em proteger os cidadãos, na tentativa de alcançar seus objetivos.

Schlink questiona a partir da constatação de que o sopesamento não estaria na necessidade se há de fato indispensabilidade do último teste na proporcionalidade. Poderia ser indispensável se o potencial da pergunta do exame da necessidade mostrado não permitisse levantar e responder o que exigem as respostas de direitos fundamentais. Contudo, para o autor, o ponto a ser questionado não é se a proporcionalidade em sentido estrito é indispensável, questionamento no sentido de que sem este exame os instrumentos para a solução de conflitos entre direitos fundamentais seriam ou não poucos ou insuficientes, mas, sim, ao contrário, se este exame em geral se compatibiliza com a objetividade e segurança exigidas das decisões judiciais. ${ }^{118}$

A resposta é negativa. O raciocínio desenvolvido por meio do sopesamento é de natureza subjetiva e decisionista, portanto sua legitimidade é unicamente política, não estando disponível aos tribunais. Não há problemas em utilizá-lo, desde que não seja como critério em decisões do tribunal constitucional, mas apenas na competência do legislador. ${ }^{119} \mathrm{O}$ sopesamento não deixa de ser subjetivo nesse âmbito, mas ao menos o poder legislativo possui legitimidade democrática para suas decisões, ao contrário do judiciário. Schlink não nega que é preciso, na sociedade, tomar decisões por meio de sopesamentos entre interesses individuais e coletivos, para e contra determinados valores e bens. Isso ocorre com o estabelecimento de preferências. No entanto, essa tarefa deve ser abandonada no âmbito judicial, pois ela não é metodologicamente possível de ser preenchida. ${ }^{120}$ Desse modo, aonde o instrumentário proporcionado pelas sub-regras da adequação e da necessidade não é efetivo, esse campo pertence ao sistema político.

Para o autor, os testes da adequação e da necessidade podem ser verificados como metodologicamente corretos, racionalmente controláveis e generalizáveis dogmaticamente. Já as operações de valoração da proporcionalidade em sentido estrito opõem-se a uma realização metodologicamente e dogmaticamente satisfatória, sendo alcançada de modo

\footnotetext{
117 Parece-me equivocado o que o Schlink diz sobre a necessidade ser mero prognóstico. Se na proporcionalidade em sentido estrito se avalia opções em relação aos direitos em jogo, na necessidade se avalia os meios em relação à intensidade da restrição. Isso também representa uma questão valorativa e de preferência. Esse ponto será comentado no tópico seguinte.

118 Cf. Bernhard Schlink, "Der Grundsatz der Verhältnismäßigkeit”, p. 459.

119 Cf. Bernhard Schlink, "Der Grundsatz der Verhältnismäßigkeit", p.

120 Cf. Bernhard Schlink, "Freiheit durch Eingriffsabwehr - Rekonstruktion der klassischen Grundrechtsfunktion”, p. 461.
} 
decisionista. ${ }^{121}$ Nos sopesamentos se pode notar somente a subjetividade do examinador e no resultado caso a caso dos julgamentos de direitos fundamentais como mais ou menos valorosos.

Com isso, reafirma-se a crítica da grande abertura para se decidir colisões entre direitos fundamentais por meio do sopesamento e sua conseqüente indeterminação metodológica e perda da consistência da decisão. Seria possível escolher, tomar decisões por meio do sopesamento, mas como não seria racionalmente controlável, atribui-se a tarefa de estabelecer preferências ao legislativo, que possui legitimidade democrática. $\mathrm{O}$ sopesamento apresentaria um campo argumentativo impossível de se estruturar.

\subsection{Concretização dos direitos fundamentais em jogo no sopesamento}

Schlink, ao analisar o método do sopesamento no âmbito da dogmática dos direitos fundamentais, diz que a sua fórmula constitui modelo, que é interpretado de acordo com diferentes situações ou âmbitos sociais. ${ }^{122}$ Nessas interpretações do modelo tem origem a dogmática de cada direito fundamental, estabelecendo, por exemplo, para os diferentes âmbitos sociais, quais são os objetivos falhos para o Estado, com quais hipóteses a realidade é constituída e são provadas ou testadas a adequação e a necessidade e qual é a posição mínima do direito a ser assegurado.

Desse modo, o modelo de sopesamento é preenchido para cada âmbito social de forma diferente. Contudo, essa diferenciação ocorre não por causa dos direitos fundamentais, mas justamente pela diferença dos âmbitos sociais, os quais estabelecem hipóteses diversas, realidades diversas e, por isso, as perguntas sobre a adequação e necessidades nesses âmbitos devem ser respondidas de maneira diferente. ${ }^{123}$ Nesse processo, são estabelecidas regras de ônus de argumentação, que significam regras que organizam a argumentação, das quais o seu sucesso depende do que é compatível e admissível para os direitos fundamentais. No entanto, o modelo de sopesamento não é sensível o suficiente para diferenciar argumentos de objetivos admissíveis e inadmissíveis. Isso ocorreria, segundo o autor, porque a pergunta do método corresponde apenas a

\footnotetext{
121 Cf. Bernhard Schlink, "Freiheit durch Eingriffsabwehr - Rekonstruktion der klassischen Grundrechtsfunktion", p. 461.

$122 \quad$ Cf. Bernhard Schlink, Abwägung im Verfassungsrecht, p. 195.

123 Cf. Bernhard Schlink, Abwägung im Verfassungsrecht, p. 200.
} 
respostas de sim ou não, se o objetivo é legítimo ou não. Perguntas como quão legítimo ou o quão valoroso o bem jurídico seria não possuiriam lugar no modelo de sopesamento. ${ }^{124}$

Além disso, a diferenciação entre meios e fins seria relativa e aberta à problematizações sobre esses pontos. ${ }^{125}$ Geralmente os objetivos em exame são tão amplos, que não são possíveis de serem justificados, visto que quanto mais indeterminado for o fim, mais difícil se torna o desenvolvimento adequado de argumentação. Como exemplo, podem-se citar objetivos amplos como a promoção da dignidade humana, o Estado de direito ou a democracia.

Tendo em vista essas observações, Schlink questiona novamente se o tribunal constitucional poderia substituir o meio escolhido pelo legislador para justificar a restrição de um direito fundamental. Nem sempre é claro qual dos meios em questão é o mais eficiente e capaz de restringir de maneira menos intensa um direito, muitas vezes o prognóstico que se faz não é possível de ser inequívoco e a pergunta sobre necessidade acaba por se situar em uma área de dúvida. Nesses casos, quando não se pode dizer que um meio é claramente desnecessário, seria negado ao tribunal constitucional um controle sobre adequação e necessidade da restrição de um direito. Isso ocorreria em especial nos casos em que o legislador possuir dificuldades no julgamento da realidade envolvida e no prognóstico a ser feito. ${ }^{126}$

Por isso, a comparação entre meios e fins também pode ser afirmada como uma comparação que tem lugar de destaque no sistema político. Ela significa, em outras palavras, a liberdade legislativa de escolher objetivos. Esse questionamento diz respeito ao fato de que o legislador precisa testar os meios e fins, mas nem sempre por meio desses testes se obtém claras definições sobre os objetivos, os procedimentos testados e o controle de obtenção como adequado e necessário para encontrar o meio certo. ${ }^{127}$ Nesses casos se questiona como o tribunal poderia argumentar contra a decisão legislativa e substituí-la. Aqui se trata de análise mais relacionada e direcionada ao exame da necessidade.

Por mais que Schlink considere, como foi comentado no tópico anterior, prognósticos como somente julgamentos técnicos, com raciocínio interpretativo possível de ser construído objetivamente, mesmo assim muitas vezes esses julgamentos se situam em uma área de incerteza, o que implica avaliações, e conseqüentemente, escolhas para o legislador, na tentativa de eleger o meio mais adequado e necessário, apesar das 
dificuldades de selecioná-lo de forma inequívoca. Nesses casos de incerteza, para o autor, prevaleceria a discricionariedade legislativa e o tribunal constitucional não poderia questionar a decisão do legislador.

Schlink é coerente, no sentido de que, quando há incerteza - para ele, em algumas situações no exame da necessidade e sempre no sopesamento - prevalece a liberdade legislativa e o tribunal constitucional não poderia intervir em tais questões. Porém, pareceme que a conclusão sobre a incerteza na necessidade acaba por relativizar o argumento anterior de que prognósticos fazem parte de uma área compreendida apenas por julgamentos técnicos. Nessa etapa há também que se comparar e preferir um meio ao outro, incorporando um raciocínio à semelhança do que é feito na etapa seguinte da proporcionalidade, ou seja, no sopesamento. É preciso, em primeiro lugar, aferir o quão eficiente são os meios em exame e comparar essas medidas de eficiência. Após, caso os meios forem igualmente eficientes, medir as intensidades de restrição - o que é feito também no sopesamento - e compará-las. A avaliação da necessidade é estruturada de tal maneira que ela contém uma pré-avaliação do que será desenvolvido na etapa seguinte, quando se comparará a intensidade de restrição de um direito em relação à importância da realização do outro.

\subsection{Incomensurabilidade e incomparabilidade}

Para analisar posteriormente a possibilidade de se fundamentar racionalmente os enunciados de preferência entre princípios no sopesamento, mostra-se importante examinar previamente a questão sob o ponto de vista da discussão sobre incomensurabilidade e incomparabilidade de bens ou direitos, que corresponde a uma das críticas ao método. Não é muito comum na literatura jurídica o exame conjunto desses esses dois debates. ${ }^{128}$ Além disso, em geral, essa discussão encontra-se em estágio inicial, não conceituando de forma clara os conceitos envolvidos e até mesmo confundindo os sentidos desses, levando às vezes a conclusões equivocadas. ${ }^{129}$ Por isso, mostra-se relevante definir esses conceitos e investigá-los com maiores detalhes, visto que esse debate é pouco explorado e as críticas geralmente são superficiais. Adiciona-se o fato de que o debate sobre a fórmula do peso

\footnotetext{
128 Nesse sentido, Virgílio Afonso da Silva, "Comparing the Incommensurable: Constitutional Principles, Balacing and Rational Decision”, Oxford Journal of Legal Studies (2011), p. 2.

129 Cf. Virgílio Afonso da Silva, Grundrechte und gesetzgeberische Spielräume, p. 173, Virgílio Afonso da Silva, "Comparing the Incommensurable: Constitutional Principles, Balacing and Rational Decision", p. 10 e Ruth Chang, "Introduction", p. 1.
} 
não é feito em conjunto com o debate sobre incomensurabilidade e incomparabilidade, e a junção desses poderia esclarecer algumas questões presentes na discussão atual. ${ }^{130}$

A pergunta central é, como sustentam alguns críticos, se a incomensurabilidade de bens ou princípios, em primeiro lugar, implica a impossibilidade de se chegar a uma decisão com critérios racionais de decidibilidade e, em seguida, o mesmo para a incomparabilidade. ${ }^{131} \mathrm{Em}$ outras palavras, se há presença de bens incomensuráveis ou incomparáveis em um sopesamento, apresentam-se problemas para o desenvolvimento do método e chegada de uma decisão? Esses problemas podem sustentar uma objeção de irracionalidade do método? É possível fundamentar enunciados de preferências em uma decisão mesmo quando os bens envolvidos forem incomensuráveis ou incomparáveis? Para responder a essas perguntas, é preciso, como pressuposto teórico, definir os conceitos envolvidos.

No debate atual, John Finnis, por exemplo, afirma que o fato de bens serem incomensuráveis faz com que não existam fundamentos racionais que justifiquem a preferência de um a outro. ${ }^{132}$ Para ele, o problema da incomensurabilidade pode ser definido como o problema da não existência de escalas racionais para pesar bens em questões de escolhas políticas e morais. ${ }^{133}$ Cabe investigar se a afirmação do autor é procedente.

David Luban, em artigo resposta, afirma que Finnis está equivocado. ${ }^{134}$ Para examinar essa controvérsia, definir o significado de comensurabilidade é fundamental: como a própria palavra diz, comensurabilidade significa que itens possuem a mesma medida comum. Seria o caso, por exemplo, de distâncias, que são comensuráveis porque podem ser mensuradas em metro, ou produtos em dólar. ${ }^{135}$ Nesse sentido, é possível observar que "medida comum" diz respeito a uma ordenação quantitativa, cardinal. A base da crítica de Finnis é que somente comparações intradimensionais - ou seja, entre bens que dividem a mesma medida, em termos cardinais - seriam possíveis e racionais.

\footnotetext{
130 No capítulo 3 o debate sobre a fórmula do peso será abordado com detalhes, além de questionamentos atuais a esse respeito.

131 Cf. Virgílio Afonso da Silva, Grundrechte und gesetzgeberische Spielräume, p. 172. As críticas, no debate sobre incomensurabilidade e incomparabilidade, são geralmente direcionadas à possibilidade de se fazer escolhas de modo racional, não direcionadas especificamente ao sopesamento.

132 Cf. Virgílio Afonso da Silva, "Comparing the Incommensurable: Constitutional Principles, Balacing and Rational Decision”, p. 7 e John Finnis, "Natural Law and Legal Reasoning”, pp. 9-10.

133 John Finnis, "Natural Law and Legal Reasoning", pp. 9-10

134 Cf. Virgílio Afonso da Silva, Grundrechte und gesetzgeberische Spielräume, p. 173, Virgílio Afonso da Silva, "Comparing the Incommensurable: Constitutional Principles, Balacing and Rational Decision”, p. 10 e David Luban, "Incommensurable Values, Rational Choice, and Moral Absolutes”, p. 66.

135 Cf. David Luban, "Incommensurable Values, Rational Choice, and Moral Absolutes".
} 
Comparações interdimensionais seriam impossíveis de serem fundamentadas, pois os bens em questão são incomensuráveis.

Observa-se que a crítica do autor, principalmente pelo exposto na última frase, acaba por tratar no mesmo plano os conceitos de incomensurabilidade e incomparabilidade: não seria possível escolher de forma racional bens incomensuráveis porque, não dividindo a mesma medida, eles seriam incomparáveis. O que se pretende mostrar aqui é que, em primeiro lugar, incomensurabilidade e incomparabilidade são de conceitos distintos. Além disso, considera-se que incomensurabilidade não implica incomparabilidade de bens; ao contrário, é justamente a incomensurabilidade requisito para que se estabeleça um raciocínio de comparação entre bens, típico do sopesamento entre princípios. $^{136}$

Explica-se, primeiramente, o porquê de se considerar que incomensurabilidade não significa incomparabilidade de bens. Para realizar uma comparação não é necessária uma medida comum precisa entre os bens, de forma cardial como metros ou quilos. ${ }^{137}$ Para um bem ser melhor do que outro, por exemplo, ele não precisa ser 2,35 unidades de valor melhor que o outro. ${ }^{138} \mathrm{O}$ que se quer dizer com isso é que itens comparáveis não precisam ser elencados de forma cardinal; um ranking sobre eles pode ser estabelecido de forma ordinal. Tendo em mente essa consideração, adota-se a definição de Ruth Chang, que reserva o termo "incomensurabilidade" para itens que não podem ser precisamente mensurados por uma escala comum de unidades de valor - ou seja, medidos de forma cardinal- e o termo "incomparabilidade" para itens que não podem ser comparados.

Em segundo lugar, a incomensurabilidade entre princípios, ou seja, a inexistência de uma medida comum, cardinal, é que faz com que surja a necessidade de se realizar um sopesamento. Porque sopesar é uma operação que diz respeito a comparar os princípios ou valores em colisão, avaliar os prós e contras de cada um e realizar uma escolha entre eles. ${ }^{139}$ Não é o caso de apenas medir dois objetos e dizer qual é maior. Para dizer qual

136 Cf. Virgílio Afonso da Silva, "Comparing the Incommensurable: Constitutional Principles, Balacing and Rational Decision", pp. 11 e ss.

137 Cf. Virgílio Afonso da Silva, Grundrechte und gesetzgeberische Spielräume, p. 174, Virgílio Afonso da Silva, "Comparing the Incommensurable: Constitutional Principles, Balacing and Rational Decision", p. 11 e Ruth Chang, "Introduction", p. 2.

$138 \quad$ Cf. Ruth Chang, "Introduction", p. 2. Sobre outros exemplos: Virgílio Afonso da Silva, Grundrechte und gesetzgeberische Spielräume, pp. 170 e ss e "Comparing the Incommensurable: Constitutional Principles, Balacing and Rational Decision", p. 11.

139 Cf. Virgílio Afonso da Silva, Grundrechte und gesetzgeberische Spielräume, p. 175 e "Comparing the Incommensurable: Constitutional Principles, Balacing and Rational Decision”, p. 11. 
distância é maior não é preciso avaliar os prós e contras de cada medida, mas apenas, cardinalmente, medi-las e ver qual é a maior.

Como o sopesamento se relaciona diretamente com a questão de comparabilidade, é preciso analisar mais atentamente esta questão. A noção básica e simplificada, segundo Ruth Chang, diz que dois itens são incomparáveis se "não há nenhuma relação positiva entre eles". ${ }^{140}$ Em outras palavras, em uma definição de acordo com a tese tricotômica, duas coisas são comparáveis se for possível definir uma como melhor que a outra ou avaliar que as duas são iguais. ${ }^{141}$ No entanto, esse conceito é limitado e, por isso, apresenta alguns problemas, como aponta a autora. Isso porque essa definição assume que o espaço lógico para relações positivas de valor para qualquer dois itens é exaurido por uma tricotomia de relações "melhor que", "pior que" e "igualmente bom". ${ }^{142}$ Segundo essa tese, se um item não é nem melhor que o outro nem pior que outro e os itens não são iguais, nada afirmativo pode ser dito sobre o que se relaciona entre eles: eles seriam incomparáveis. ${ }^{143}$

Para Ruth Chang, a tese tricotômica é falsa. Para ela há uma quarta relação positiva de valor - a paridade - que também não se situa na incomparabilidade, além dos três elencados pela tese tricotômica. ${ }^{144}$ Paridade, para a autora, é central para o argumento contra incomparabilidade. Ele se mostra essencial principalmente para examinar os casos de impasses no sopesamento, ou seja, nos casos em que os princípios em jogo aparentemente são avaliados com pesos iguais e não se sabe qual deles preferir. ${ }^{145}$ Por enquanto, mostra-se possível trabalhar com essa definição preliminar para caracterizar a comparabilidade.

Considerando que dois itens são comparáveis se for possível definir um deles como melhor que o outro ou os dois como iguais, e que essa relação não é feita por meio de uma medida comum, mas sim por meio de avaliações e escolhas, a pergunta que se levanta intuitivamente de tal raciocínio seria a seguinte: um item seria melhor que o outro como ou em quê? Ou iguais em que sentido? Isso porque simplesmente falar que um item é melhor

\footnotetext{
$140 \quad$ Ruth Chang, "Introduction”, p. 4.

141 Cf. Ruth Chang, "Introduction”, p. 4, Virgílio Afonso da Silva, Grundrechte und gesetzgeberische Spielräume, p. 137.

${ }_{142}$ Cf. Virgílio Afonso da Silva, "Comparing the Incommensurable: Constitutional Principles, Balacing and Rational Decision”, p. 21.

143 Ruth Chang, "Introduction", p. 4.

144 Sobre esse ponto de vista da autora, ver "The Possibility of Parity", Ethics 112 (2002): 659-88 e Virgílio Afonso da Silva, Grundrechte und gesetzgeberische Spielräume, p. 184 e "Comparing the Incommensurable: Constitutional Principles, Balacing and Rational Decision”, p. 21.

145 Sobre essa questão, ver Virgílio Afonso da Silva, "Comparing the Incommensurable: Constitutional Principles, Balacing and Rational Decision”, pp. 21 e ss.
} 
que o outro parece ser extremamente indeterminado e a escolha entre esses itens restaria em aberto, passível de julgamentos de vontade, sem maiores fundamentações. Como seria possível escolher racionalmente nesses casos?

Para entender essa operação, acredita-se que é necessário estabelecer como requisito que todas as comparações ocorram em termos de um valor. ${ }^{146}$ Esse valor significa qualquer consideração com respeito do qual uma significante comparação por meio de avaliações pode ser feita. Isso corresponde a um valor base da comparação. Explica-se: uma comparação sempre é feita em relação a um valor: algo é melhor que outro em relação a um valor determinado, como, por exemplo, usar metrô é melhor que dirigir um carro em São Paulo em termos de tempo de deslocamento; mas, se o valor for conforto, pode ser que dirigir um carro seja melhor do que usar metrô. É o valor que determina se um bem é melhor ou igual que o outro. Nesse sentido, destaca-se a importância de se ter valor no qual se baseiam as comparações, já que coisas só podem ser melhores ou piores em respeito a algum critério. $^{147}$

Considerando esse novo conceito em jogo, Ruth Chang, que é contrária a tese tricotômica, redefine o que significa incomparabilidade: "dois itens são incomparáveis em relação a um valor base se, para cada relação positiva de valor relativizada para esta base, não é verdade que essa relação exista entre os itens". ${ }^{148}$ É com esse conceito que se pretende trabalhar a noção de incomparabilidade. Adotar esse conceito é importante, pois se acredita que é a partir da noção de valor base que se pode justificar racionalmente uma escolha. Isso porque cada razão que justifica uma escolha tem sua força justificadora em virtude da comparação de alternativas. ${ }^{149} \mathrm{O}$ que determina a comparabilidade entre alternativas seria justamente o valor no qual se baseia a comparação.

Essa definição é essencial para que se analisem as possibilidades de uma precedência condicionada no sopesamento ser definida de forma racional ou não. Para examinar essas situações, mostra-se relevante observar os argumentos próincomparabilidade que Ruth Chang refuta. ${ }^{150}$ Isso porque muito desses argumentos

\footnotetext{
146 Cf. Virgílio Afonso da Silva, Grundrechte und gesetzgeberische Spielräume, p. 176 e "Comparing the Incommensurable: Constitutional Principles, Balacing and Rational Decision”, p. 12 e Ruth Chang, "Introduction", p. 5.

147 Cf, Ruth Chang, "The Possibility of Parity”, pp. 665 e ss, Virgílio Afonso da Silva, Grundrechte und gesetzgeberische Spielräume, p. 176 e "Comparing the Incommensurable: Constitutional Principles, Balacing and Rational Decision”, p. 12.

$148 \quad$ Ruth Chang, "Introduction", p. 6.

149 Cf. Virgílio Afonso da Silva, "Comparing the Incommensurable: Constitutional Principles, Balacing and Rational Decision", p. 14 e Ruth Chang, "Introduction", pp. 12-13.

150 Cf. Ruth Chang, "Introduction”, pp. 13-14.
} 
correspondem a situações nas quais os críticos afirmam a impossibilidade de existência de critérios racionais de decidibilidade no sopesamento. Refutando-se argumentos próincomparabilidade de princípios no sopesamento, também se refutam implicações de irracionalidade no método. Pretende-se aqui apontar os principais argumentos que se relacionam ao tema expostos pela autora.

$\mathrm{O}$ primeiro argumento pró-incomparabilidade apresentado diz respeito à diversidade de valores. Nessa crítica, fala-se que alguns bens não podem ser comparados porque pertencem a gêneros diferentes. ${ }^{151}$ A idéia central desse argumento é que alguns itens são tão diferentes que não existe base comum na qual uma comparação pode ser feita. A chave para essa controvérsia está no conceito, desenvolvido pela autora, de comparações "nominal-notável". 152

O notável diz respeito a um bem com excepcional valor e o nominal um bem com pouco valor. Assim, o notável é sempre melhor que o nominal com respeito ao valor no qual eles são respectivamente nominal e notável. O exemplo dado pela autora é entre Mozart, Michelangelo e Talentessi, um pintor muito ruim. O valor base estabelecido é o talento. Sabe-se que Mozart ou Michelangelo são melhores que Talentessi, pois ambos são notáveis em relação ao valor talento, e Talentessi é apenas nominal. Se for possível comparar os dois com Talentessi, é provável que também seja possível comparar Mozart e Michelangelo entre si por meio do valor talento. Desse modo, o argumento da diversidade de valores por si só não é motivo para ensejar incomparabilidade.

Outro argumento apresentado, que é também utilizado com frequiência como uma objeção ao sopesamento, corresponde a "dupla direção" de méritos comparativos, ou seja, a condição que um item é melhor que o outro em algum sentido do valor base, mas pior em outros pontos. ${ }^{153}$ Nesses casos, sustentam os críticos, não seria possível tomar uma decisão, o que ensejaria a incomparabilidade entre bens. No entanto esse argumento não pode ser fundamento para a incomparabilidade, já que há de fato comparação entre bens. O que pode ocorrer nesses casos é um impasse na decisão, pois não se sabe qual bem é a melhor escolha considerando todos os aspectos envolvidos. Mas esse impasse não enseja a incomparabilidade.

$\begin{array}{ll}151 & \text { Cf. Ruth Chang, "Introduction", p. } 14 . \\ 152 & \text { Cf. Ruth Chang, "Introduction", p. } 14 . \\ 153 & \text { Cf. Ruth Chang, "Introduction", p. } 17 .\end{array}$ 
Fala-se também sobre a multiplicidade de rankings legítimos de alternativas. ${ }^{154} \mathrm{O}$ argumento central seria que quando existem rankings múltiplos e nenhum prevalece, então os itens seriam incomparáveis. Acredita-se, no entanto, que o fato de não haver uma forma única correta de pesar os aspectos variados relacionados ao valor base não significa que os itens sejam incomparáveis. Esse argumento também se relaciona com os casos de impasse e paridade.

O último argumento diz respeito a pequenos melhoramentos entre itens. ${ }^{155}$ Nesse caso, se nenhum item é melhor do que outro e um melhoramento em um deles não faz com que um deles seja melhor do que o outro, então eles seriam incomparáveis. Novamente é um argumento que tem por base a tese tricotômica, já que os itens podem estar em uma relação de paridade, o que não implica incomparabilidade. A questão é que se foi possível avaliar os dois itens como não iguais, apesar de não ter sido possível dizer qual é melhor do que outro, houve uma comparação. Isso é relevante para se entender situações específicas de impasse no sopesamento, especialmente para os casos de discricionariedade. ${ }^{156}$

A partir deste exame da questão sobre incomensurabilidade e incomparabilidade, sustenta-se que, em primeiro lugar, se podem rejeitar as críticas da irracionalidade ligadas à incomensurabilidade dos direitos em colisão, porque é justamente essa característica que possibilita uma operação de sopesamento e, em segundo lugar, considera-se que os princípios em questão são comparáveis, o que permite a realização de uma escolha fundamentada no sopesamento, considerando um valor base da comparação. Não se pergunta, em abstrato, o que seria melhor ou que o valeria mais, como, por exemplo, liberdade de imprensa ou o direito à privacidade, mas sim se pergunta em relação a uma situação específica, um conflito concreto. ${ }^{157}$

\subsection{Sopesamento como metáfora e indefinição de sua linguagem}

\footnotetext{
$154 \quad$ Cf. Ruth Chang, "Introduction”, p. 22.

155 Cf. Virgílio Afonso da Silva, "Comparing the Incommensurable: Constitutional Principles, Balacing and Rational Decision", pp. 22 e ss. e Ruth Chang, "Introduction", pp. 23 e ss.

156 Existe discussão atual que trata de aspectos específicos desta temática, que será apresentada em linhas gerais no tópico sobre "variações ou complementações do modelo de sopesamento e fórmula do peso". No entanto, não se pretende aqui analisar detalhadamente esta discussão, pois fugiria do escopo deste trabalho. Sobre discricionariedade, ver Virgílio Afonso da Silva, Grundrechte und gesetzgeberische Spielräume.

${ }_{157} \quad$ Cf. Virgílio Afonso da Silva, Grundrechte und gesetzgeberische Spielräume, pp. 173 e ss. e "Comparing the Incommensurable: Constitutional Principles, Balacing and Rational Decision", pp. 22 e ss.
} 
Alguns autores direcionam sua crítica ao sopesamento por meio da exposição do método, sua metáfora de pesos e a indefinição de linguagem. Essa objeção se encontra dentro do grupo sobre a indeterminação conceitual do método, além de questões relacionadas à incomensurabilidade e incomparabilidade.

Stravros Tsakyrakis, por exemplo, trabalha inicialmente com a idéia de sopesamento como metáfora, para depois criticá-la, apontando ser aberta demais e incapaz de definições, para mais posteriormente abordar e criticar o método do ponto de vista da incomensurabilidade. ${ }^{158}$ Para o autor, o sopesamento é uma metáfora poderosa, que demanda a captura, como um todo, do melhor método de decisão.

Essa metáfora é estabelecida pelo raciocínio básico de que as pessoas colocam, de um lado da balança, considerações em favor de uma ação e, do outro lado, considerações contra isso. Elas pesam os dois lados e chegam a uma decisão que segue os prós e contras do processo de sopesamento. Nessa descrição, o método parece ser uma forma básica, até “quase intuitiva", de se argumentar. ${ }^{159}$ Contudo, para o autor, essa metáfora é muito vaga para incluir a grande variedade de razões e ações humanas. Além disso, essa metáfora sugeriria precisão. Desse ponto surge o problema que escalas, enquanto símbolo de justiça, expressam a questão de tentar conferir a precisão das ciências naturais a decisões dos tribunais, segundo o autor. ${ }^{160}$

Além disso, a aplicação do sopesamento nos tribunais poderia apontar certa ambigüidade da metáfora, pois pode não ser expresso de forma clara o que é pesado na operação e nem como é pesado, assim como quem deveria ser o responsável por sopesar. Dessas indefinições se seguiria a não estabilidade do método, pois a proteção de acordo com a Constituição não poderia ficar estável em nenhuma hipótese, já que sempre seria condicionada a circunstâncias vaiadas e dependentes de como será desenvolvido o sopesamento.

A metáfora também não aborda como interesses variados deveriam ser medidos ou pesados, ou se haveria a possibilidade de se introduzir uma métrica comum quantitativa, apesar de passar a imagem da possibilidade de tal. Para o autor, em especial, o único modo de se estabelecer uma métrica comum seria adotando certa forma de utilitarismo, o que significaria adotar uma teoria moral que assumisse que todos os interesses (por exemplo, dinheiro, felicidade ou prazer) fossem possíveis de serem reduzidos a alguma métrica

\footnotetext{
158 Cf. Stravros Tsakyrakis, "Proportionality: An assault on human rights?".

159 "In a sense, balancing appears to be a basic way of reasoning and, certainly, a basic way of practical reasoning”. Stravros Tsakyrakis, "Proportionality: An assault on human rights?”, p. 469.

$160 \quad$ Stravros Tsakyrakis, "Proportionality: An assault on human rights?", p. 470.
} 
compartilhada, e que, uma vez traduzidos nesse critério comum, os interesses poderiam ser medidos entre si, sem restrições. ${ }^{161}$

No entanto, além dessa opção representar uma estratégia de alto risco, já que não é possível quantificar valores ou direitos como maçãs ou laranjas, ${ }^{162}$ ela descaracterizaria o raciocínio do sopesamento. O método "só faz sentido contra um conjunto de vários valores em conflito. Se todos os valores forem reduzidos a uma métrica comum, o problema que levanta a necessidade por um método de sopesamento dissolve". ${ }^{163}$ Somente faz sentido comparar direitos no sopesamento não tendo uma mesma métrica, pois, se tivessem, seria somente o caso de medir e não avaliar os prós e contras de cada lado. ${ }^{164}$ Desse modo, é preciso rejeitar o mito da precisão matemática na metáfora.

Há também a apresentação do sopesamento em sentido mais estrito, referente à aplicação do método dentro da estrutura da proporcionalidade. Nesse sentido há mais críticas de Tsakyrakis, porque esse seria um teste que fingiria ser objetivo, neutro e totalmente estranho a qualquer fundamentação moral. ${ }^{165}$ Por esse motivo o autor sustenta a não aceitação do sopesamento como método de resolver casos de direitos humanos. Avaliações morais seriam inevitáveis e o método conduziria a idéia ilusória de precisão matemática e quantificação objetiva de valores.

Outra controvérsia levantada diz respeito a quais contornos os argumentos deveriam tomar no sopesamento. O que ocorre, segundo o autor, não é uma reconstrução racional dos passos na argumentação, que levariam a uma decisão particular, mas somente uma fundamentação de poucas palavras, que falha em identificar a contribuição de diferentes argumentos no sopesamento. ${ }^{166}$

O juízo que se faz por meio do sopesamento também seria um problema. Para o autor, deveria se investigar o que é certo ou errado nos casos envolvendo direitos fundamentais, e não se algo é apropriado, adequado, intenso ou de grande alcance. Parece ser aqui mais uma questão de opção teórica do autor, que não concorda com os pressupostos da teoria dos princípios, mas está de acordo com outras teorias de direitos

\footnotetext{
161 Cf. Stravros Tsakyrakis, "Proportionality: An assault on human rights?”, p. 471.

162 Segundo o autor, somente os utilitaristas mais radicais sustentariam uma quantificação desse nível para direitos e valores.

163 Stravros Tsakyrakis, "Proportionality: An assault on human rights?", p. 471.

164 Sabe-se que, por exemplo, a quantidade de três quilos de maçã é mais pesada do que dois quilos de laranja. Não é necessário submeter essa quantia de maçãs e laranjas a um sopesamento para saber qual é a mais pesada. Como se verá com mais detalhes posteriormente, a incomensurabilidade é pressuposto e não objeção ao sopesamento. Sobre essa questão, ver Virgílio Afonso da Silva, Grundrechte und gesetzgeberische Spielräume, pp. 173 e ss., e Jan-R. Sieckmann, "Ponderación autonoma", p. 144, nota 40.

$165 \quad$ Cf. Stravros Tsakyrakis, "Proportionality: An assault on human rights?", p. 474.

166 Cf. Stravros Tsakyrakis, "Proportionality: An assault on human rights?", p. 475.
} 
fundamentais. Essa visão teórica em particular levaria, na opinião de Tsakyrakis, a uma completa erosão da noção de direitos humanos. ${ }^{167}$ Por fim, conclui que o sopesamento com a sua retórica obscurece as considerações morais que estão no centro das questões de direitos humanos e priva a sociedade de um discurso moral que é indispensável. ${ }^{168} \mathrm{~A}$ melhor maneira de resolver os desacordos na sociedade seria por meio de um debate totalmente livre e aberto, e não por meio de fórmulas que pretendem ser neutras, mas acabam mascarando os juízos morais presentes nas decisões judiciais.

Outro autor que aborda a questão da linguagem e as objeções desse ponto é Jacco Bomhoff. ${ }^{169}$ É a crítica do perigo do uso retórico do método devido à corrente de "entusiastas" da ponderação, que a vêem como uma moldura neutra e linguagem comum acessível a diferentes sistemas jurídicos. Essa idéia da existência de linguagem comum poderia mostrar o quanto o método é aberto e possível de ser interpretado e aplicado das mais variadas formas, dependendo do ordenamento.

Há, por exemplo, diferenças nos tipos de parâmetros das cortes em sistemas diferentes ao pesar os direitos. Para ele, há muitas ambigüidades na linguagem do sopesamento para se dizer o que está sendo comparado. Desse modo, cortes em todo mundo têm usado sistematicamente o método sem esclarecer o que de fato sua metáfora expressa, adotando como uma nova língua franca. Mais uma vez, com essa indefinição e abertura, qualquer questão constitucional pode ser uma questão de sopesamento. ${ }^{170}$ Além disso, o discurso do sopesamento acaba sendo de acordo com o contexto específico, o que dificulta um desenvolvimento de enfoque universalista do método, de transposição para todos os países. ${ }^{171}$ Os argumentos envolvidos na ponderação são geralmente formas abertas, mas incorporam elementos de acordo com o contexto.

Christensen e Fischer-Lescano também fazem parte de um grupo mais recente de críticas sobre o sopesamento, que não possui como ponto central a questão da separação de poderes, caso de autores como Böckenförde, visto anteriormente. Seu ponto de vista é desenvolvido a partir, principalmente, de considerações sobre linguagem e argumentação. Para eles, o sopesamento é mais uma questão de argumentação do que do estabelecimento de uma hierarquia de direitos. O problema aqui seria se o sopesamento funcionaria

\footnotetext{
167 Cf. Stravros Tsakyrakis, "Proportionality: An assault on human rights?”, p. 489.

168 Cf. Stravros Tsakyrakis, "Proportionality: An assault on human rights?", p. 493.

169 Cf. Jacco Bomhoff, "Balancing, the Global and the Local: Judicial Balancing as a Problematic Topic in Comparative (Constitutional) Law".

170 Relacionada a essa crítica, ver Böckenförde e o "estado judicial".

171 Cf. Jacco Bomhoff, "Balancing, the Global and the Local: Judicial Balancing as a Problematic Topic in Comparative (Constitutional) Law", p. 576.
} 
realmente na argumentação ou se ele seria somente uma fachada retórica para a obtenção de decisões não legítimas para o direito.

Esses dois autores ressaltam o fato do método servir como uma metáfora na argumentação jurídica, não sendo o sopesamento uma técnica de obtenção de um determinado resultado, mas somente uma imagem para o resultado. ${ }^{172}$ É algo determinado de forma prática. Para esses autores, a palavra em si já demonstra uma indefinição. Isso porque sempre se tenta explicar o significado da palavra por meio da própria palavra, não haveria um conceito que falasse realmente o que o sopesamento faz. ${ }^{173}$ A definição estaria sempre como algo ligado a pesos, mas esta acaba sendo circular e não esclarecendo como é desenvolvimento o método em estudo. Fala-se em decidir entre dois ou mais objetos, mas não se fala como. Segundo eles, a sintaxe da explicação não esclarece o que é efetivamente feito na ponderação. Por isso, a dúvida apresentada diz respeito se o conceito de sopesamento seria ou não metodologicamente definível.

A questão é que um método de sopesamento racional não poderia ser tomado somente textualmente, só poderia ser trabalhado como metáfora. Seria preciso desenvolver, para além disso, uma métrica em comum para os pesos dos direitos em conflito. Nesse caso, os autores fixam-se na construção de um centro do ordenamento jurídico baseado na idéia de justiça. A crítica estaria no fato de que, sem esse centro, não seria possível estabelecer uma relação métrica entre os princípios ou valores colidentes: o sopesamento em si não é capaz de estabelecê-la. ${ }^{174}$ Haveria, então, uma falha enquanto técnica. Essa constatação os leva a afirmar a arbitrariedade das decisões envolvendo o método e as lesões advindas para a democracia e o Estado de Direito, porque o centro do sistema permanece indefinido na sua aplicação em si, deixando o seu preenchimento de conteúdo ao arbítrio dos aplicadores. ${ }^{175}$

Além disso, há o problema dos argumentos heterogêneos, com os quais é preciso lidar na aplicação do método. Esses argumentos vêm de contextos e de interlocutores diferentes. Por exemplo, sobre a pergunta se a universidade deveria ou não ter maior discricionariedade na elaboração do exame de final de curso. ${ }^{176}$ Por meio dessa pergunta, é possível argumentar tanto pontos a favor como contra. Um professor da universidade

\footnotetext{
172 Cf. Ralph Christensen e Andreas Fischer-Lescano, Das Ganze des Rechts, p. 149.

173 Cf. Ralph Christensen e Andreas Fischer-Lescano, Das Ganze des Rechts, p. 151. "Damit erhärtet sich der Verdacht, dass keiner so recht zu sagen vermag, was er eigentlich tut, wenn er von sich behaupt abzuwägen“.

174 Cf. Ralph Christensen e Andreas Fischer-Lescano, Das Ganze des Rechts, p. 169.

175 Cf. Ralph Christensen e Andreas Fischer-Lescano, Das Ganze des Rechts, pp. 169-170.

176 Cf. Ralph Christensen e Andreas Fischer-Lescano, Das Ganze des Rechts, p. 170.
} 
poderia apresentar pontos favoráveis, enquanto que o reitor poderia ser contrário a tal posição. Se fosse dado um argumento para cada lado poderia parecer que a situação encontrar-se-ia em um impasse, pois não prevaleceria nem a argumentação favorável, nem a contrária. No entanto, o que este resultado mostra para a argumentação é incerto, porque os dois argumentos são baseados em contextos diferentes, no caso, um vindo de um professor e outro do reitor. ${ }^{177} \mathrm{~A}$ dúvida estabelecida diz respeito a qual seriam os pesos desses dois argumentos e se seria possível comparar argumentos de contextos heterogêneos, como o do exemplo. Esse fenômeno seria exatamente o que acontece na argumentação do sopesamento.

Para minimizar esse problema, os autores falam que é preciso estabelecer pesos relativos dos contextos e estabelecer a avaliação como se fosse em único contexto. ${ }^{178}$ Assim se tornaria possível preencher uma precedência de pesos. Contudo, continuaria a dificuldade de como as prioridades deveriam ser construídas. Isso ocorreria por causa da existência de uma metáfora em sentido quantitativo no sopesamento. A argumentação, no entanto, trata de questão de qualidade, e não quantidade. ${ }^{179}$ Se se quiser comparar o aspecto quantitativo, precisa-se de uma qualidade compartilhada como fundamento.

Tendo em mente que os argumentos no sopesamento não são classificados conforme aspectos quantitativos, surge outro problema para os autores: se o sopesamento depender de fundamento de qualidade de sua argumentação, ele não pode ser um método por si mesmo. ${ }^{180} \mathrm{O}$ sopesamento seria sugestão para a busca e ordenação de argumentos, mas não uma técnica em si, "porque os argumentos não possuem um peso específico ou poderiam ser expressados como valores": seria então somente o passivo de outras técnicas ou reflexões determinadas. ${ }^{181} \mathrm{O}$ sopesamento de forma isolada mascararia a decisão e se estabeleceria independente de argumentação no procedimento, se escondendo em uma fachada retórica. Mas, ao mesmo tempo, a questão se torna um visível problema da argumentação jurídica. Por isso, os autores concentram-se a partir desse ponto em uma análise da argumentação para tratar do problema. A dúvida seria como trabalhar a

\footnotetext{
177 Cf. Ralph Christensen e Andreas Fischer-Lescano, Das Ganze des Rechts, p. 170.

178 Cf. Ralph Christensen e Andreas Fischer-Lescano, Das Ganze des Rechts, p. 171. Parece que a sugestão seria, no limite, a de inserir outra variável a respeito dos contextos em uma fórmula do peso. Sobre a fórmula do peso, ver tópico 7.2.

179 Cf. Ralph Christensen e Andreas Fischer-Lescano, Das Ganze des Rechts, p. 171.

180 Cf. Ralph Christensen e Andreas Fischer-Lescano, Das Ganze des Rechts, p. 172.

181 Cf. Ralph Christensen e Andreas Fischer-Lescano, Das Ganze des Rechts, p. 172.
} 
argumentação com a incomensurabilidade de valores e direitos, que são avaliados no sopesamento. $^{182}$

A incomensurabilidade ocorre quando sistemas entram em concorrência e conflito entre si. No entanto, não é o mesmo de sistemas incomparáveis. Isso porque "quando os sistemas de orientação a respeito de um e outro são incompatíveis e incomparáveis, então não há nada que se possa estabelecer uma relação entre eles. A incomensurabilidade não seria nem detectada [nesse caso]. Mas quando se pode detectá-la, então há pelo menos um aspecto de comparação". ${ }^{183}$ Em outras palavras, incomensurabilidade não significa total falta de parâmetro, nem sistemas que simplesmente não conversam entre si por serem totalmente diversos. Esta hipótese parece ser o caso dos direitos no sopesamento.

Por fim, na tentativa de analisar o que consiste a tarefa da argumentação, os autores ressaltam que o juiz não toma a decisão isoladamente, apenas de acordo com sua opinião. Há todo um procedimento de decisão a ser considerado. A controvérsia é que "em toda decisão há um elemento de pura decisão, que não pode ser deduzido do conteúdo da norma". ${ }^{184}$ Há decisão por meio de uma eliminação autoritária da dúvida. Esse é o paradoxo da decisão: existem várias alternativas possíveis de serem escolhidas, mas é preciso escolher somente uma delas para que haja decisão, apesar das outras opções serem tão plausíveis quanto à elegida. ${ }^{185}$

Desse modo, não se consegue eliminar totalmente o aspecto da autoridade de quem decide. Por isso, o juiz precisa ser legitimado de alguma forma, seja por meio de autoridade ou bons fundamentos. Mas, por outro lado, como indicado pelos autores, é preciso considerar que interpretar não é própria inspiração do operador do direito. A decisão judicial não está isolada no ordenamento jurídico, mas se relaciona com métodos, procedimentos, sujeitos de direito, amici curiae, observação dos meios de comunicação e também a observação por meio do sistema político - e, é claro, a relação entre todos esses elementos.

O que é interessante notar por meio dessa conclusão dos autores, na opinião deste trabalho, é que não é possível exigir uma decisão totalmente objetiva para o direito, que a legitime integralmente. Sempre haverá certa escolha do operador do direito, não sendo possível eliminar totalmente essa influência. Existem métodos, critérios, fundamentações,

\footnotetext{
182 Cf. Ralph Christensen e Andreas Fischer-Lescano, Das Ganze des Rechts, p. 197.

183 Cf. Ralph Christensen e Andreas Fischer-Lescano, Das Ganze des Rechts, p. 203.

184 Cf. Ralph Christensen e Andreas Fischer-Lescano, Das Ganze des Rechts, p. 222. Carl Schmitt, Der Hüter der Verfassung, 1931.

$185 \quad$ Cf. Ralph Christensen e Andreas Fischer-Lescano, Das Ganze des Rechts, p. 226.
} 
variadas formas nas quais se apóia a argumentação, mas isso apenas posterga o momento final de "decisão de autoridade", por meio do poder do juiz. No entanto, acredita-se que essa conclusão também possibilita e aparece a favor do desenvolvimento do sopesamento por meio de critérios racionais de decidibilidade, e não contra. Isso porque, em primeiro lugar, acredita-se que o sopesamento não representa um método ou fórmula vazia, ao contrário do que os autores tentam sustentar. É possível identificar fundamentações específicas relacionadas ao raciocínio ponderativo, como, por exemplo, as expressadas por meio da lei do sopesamento e da fórmula do peso. Além disso, métodos jurídicos se desenvolvem por meio da argumentação. Se se seguisse a linha de raciocínio sustentada pelos autores, não haveria nenhum método em si mesmo, totalmente desvinculado da argumentação jurídica.

Desse modo, o que foi apontado aqui pelos autores representa o máximo possível para tirar a arbitrariedade do direito, porque operar argumentos com a precisão de fórmulas matemáticas não parece ser algo plausível nesse ramo das ciências. ${ }^{186}$ Esse argumento vale para a questão do sopesamento explorada aqui. Levando em conta essas conclusões e considerações dos autores, acredita-se ser possível dizer que, apesar de o núcleo da decisão ponderativa ser um juízo subjetivo, o sopesamento pode estar ligado a pretensões de correção e objetividade, podendo ser concebido como uma estrutura racional, da qual resultam exigências de racionalidade válidas. ${ }^{187}$ Para isso precisa-se investigar as possibilidades de fundamentação dos juízos no método. Esse ponto será detalhado no próximo capítulo.

\footnotetext{
186 No mesmo sentido, Virgílio Afonso da Silva, Grundrechte und gesetzgeberische Spielräume, p. 102 e ss. e Jan-R. Sieckmann, "Corrección y objetividad en el modelo de principios".

187 Cf. Jan-R. Sieckmann, "Ponderación autónoma", p. 138.
} 
MODELO E ESTRUTURA DE SOPESAMENTO

\subsection{Objetivos do capítulo}

Após ter acompanhado e examinado o debate teórico a respeito da racionalidade do sopesamento, pretende-se, neste capítulo, se concentrar em uma análise da estrutura do método. Considerando o debate anterior, os modelos de sopesamento existentes e sua estrutura, objetiva-se estudar por meio de qual modelo do método poderia haver maiores possibilidades de desenvolver critérios racionais de decidibilidade.

Para atingir esses objetivos, parte-se da conceituação de racionalidade para o direito. Esse conceito é relevante para que se analisem as possibilidades de existência de critérios racionais de decidibilidade no desenvolvimento do sopesamento. Desse modo, a partir desse conceito é que se irá examinar sua estrutura, no intuito de investigar se a decisão decorrente da aplicação do método pode ser intersubjetivamente justificada, assim como a argumentação empregada.

Este capítulo tem também como ponto de partida a pergunta sobre com qual modelo de sopesamento se pretende trabalhar, para, em seguida, examinar com detalhes a estrutura do método. Acredita-se que a procedência das críticas expostas anteriormente depende de qual modelo de ponderação o autor as sustenta. A partir dessa definição se examinará formas de desenvolvimento do método tendo em vista um modelo fundamentado. Nesse ponto se retomarão as críticas analisadas, averiguando-se em quais aspectos são procedentes e em quais não, a fim de se entender quais são as principais falhas apontadas em um determinado modelo de sopesamento sinalizado pelos críticos e que vem sendo aplicado em significativo número de cortes constitucionais em vários países. ${ }^{188}$ Assim, poder-se-ia examinar até que ponto seria possível desenvolver critérios racionais de decidibilidade no método.

\subsection{Esclarecimento preliminar: qual a racionalidade para o direito ${ }^{189}$}

\footnotetext{
188 Cf. Introdução do trabalho.

189 Ressalva-se que não se pretende, nesse tópico, exaurir o grande debate existente sobre objetividade e racionalidade no direito. Apenas objetiva-se estabelecer pressupostos teóricos do tema com os quais se irá trabalhar nos tópicos seguintes da pesquisa.
} 
Antes de prosseguir na análise do método do sopesamento, faz-se necessário um esclarecimento preliminar a respeito de qual a racionalidade que se procura e que é desejável para o direito. Esse conceito é fundamental para que se afirme ou não a possibilidade de critérios racionais de decidibilidade no desenvolvimento da ponderação.

Em primeiro lugar, o que se pretende deixar claro nesse tópico é que a racionalidade possível das ciências sociais no geral, inclusive o direito, não é a mesma que pode ser estabelecida para as ciências naturais; não se pode chegar a uma exatidão matemática ou a um modelo matemático-geométrico na decisão jurídica nem por meio do método do sopesamento, nem por meio da argumentação no geral. ${ }^{190}$ Isso se deve ao caráter peculiar do alvo do conhecimento de qualquer trabalho das ciências sociais.

Essa limitação é bem explicada por Weber, que afirma que não existe análise científica puramente "objetiva" da vida cultural, ou dos "fenômenos sociais", que seja independente de determinadas perspectivas especiais e parciais. ${ }^{191}$ Isso ocorre porque "nenhum conhecimento dos acontecimentos culturais poderá ser concebido senão com base na significação que a realidade da vida, sempre configurada de modo individual, possui para nós em determinadas relações singulares". ${ }^{192}$ Desse modo, conclui o autor que "o conhecimento científico-cultural tal como o entendemos encontra-se preso a premissas "subjetivas" pelo fato de apenas se ocupar daqueles elementos da realidade que apresentem alguma relação, por muito indireta que seja, com os acontecimentos a que conferimos uma significação cultural". ${ }^{193}$

Por isso se acredita não ser possível buscar uma racionalidade estrita que exclua, por completo, qualquer subjetividade na interpretação e na aplicação do direito. ${ }^{194} \mathrm{Nem}$ mesmo os positivistas afirmavam a existência de um processo estritamente racional e objetivo de interpretação jurídica. Uma concepção estritamente positivista possui limites imprecisos e deixa espaços, que precisam ser preenchidos por meio da interpretação.

\footnotetext{
190 Em sentido semelhante, Virgílio Afonso da Silva, Grundrechte und gesetzgeberische Spielräume, p. 102.

191 Max Weber, A “objetividade” do conhecimento nas ciências sociais. São Paulo: Ática, 2006, p. 43.

192 Max Weber, A "objetividade" do conhecimento nas ciências sociais. P. 57.

193 Max Weber, A "objetividade" do conhecimento nas ciências sociais, p. 60. Interessante é o comentário de Gabriel Cohen sobre o texto de Weber: "Assim como não se pode pedir à ciência que dê orientação normativa aos homens, não cabe esperar dela que forneça alguma fórmula universal que explique tudo. O conhecimento científico sempre incide sobre aspectos limitados da realidade, até porque o número de ocorrências é infinito no espaço e no tempo e jamais pode ser captado no todo. Isso, para Weber, é básico não como algo a ser anotado e deixado de lado, mas como fundamento do modo como a questão será tratada".

194 Cf. Virgílio Afonso da Silva, O conteúdo essencial dos direitos fundamentais e a eficácia das normas constitucionais. São Paulo: 2005, p. 190.
} 
Quem critica, em especial, o sopesamento como um método puramente subjetivo parece supor que existem outros métodos na argumentação jurídica que possibilitariam uma racionalidade matemática, o que nem a subsunção pode conferir: regras não retiram certa discricionariedade do juiz para apreciar normas. A mesma regra pode permitir mais de uma interpretação e muitas vezes as normas são preenchidas com conceitos determinados por experiências ou juízos de valores dos operadores do direito. Assim até a subsunção está longe de ser objetiva e rigorosamente previsível, deixando ao intérprete amplo espaço para avaliações e escolhas. ${ }^{195}$

Por isso, nesse trabalho, rejeita-se uma pretensão de hiper-racionalidade do sopesamento. A aplicação do método não pode ser em sentido total racional. Não se pode garantir uma objetividade em sentido forte, pois esta é uma utopia, que em nenhum campo normativo pode ser alcançada ou obtida. ${ }^{196}$ Nesse sentido, a racionalidade para o direito e para o sopesamento só é possível dentro de um limite determinado, ou seja, uma racionalidade em sentido fraco. ${ }^{197}$

Cabe aqui apontar como trabalhar com essa racionalidade em sentido fraco, como ela pode ser desenvolvida ou obtida. Em primeiro lugar, uma racionalidade em sentido fraco não implica mero decisionismo por parte dos juízes, ou seja, não se trata de julgar livremente conforme a vontade, mas conforme razões, no esforço de justificar cada passo da decisão e também no esforço desta ser universalmente aceitável por causa de sua justificação. Em linhas gerais, se pode dizer que a possibilidade de objetividade no direito diz respeito à possibilidade de "ordenar a subjetividade" do juiz na sua argumentação, ${ }^{198} \mathrm{e}$ isso ocorre por meio da construção de critérios e parâmetros na decisão judicial, geralmente organizados em um método.

Método, em sentido amplo, significa simplesmente um caminho, um procedimento, seja intelectual ou material. ${ }^{199}$ Já em uma definição em sentido estrito, método é “o conjunto ordenado de procedimentos intelectuais, e eventualmente materiais, que se empregam para um determinado tipo de atividades; estes procedimentos são meios que apontam a certos aspectos de um tipo de objetos (reais ou ideais), para os quais o método é

195 Cf. Virgílio Afonso da Silva, O conteúdo essencial dos direitos fundamentais e a eficácia das normas constitucionais, pp. 190-191, Ana Paula de Barcellos, Ponderação, racionalidade e atividade jurisdicional, p. 54 Em sentido semelhante, Aleksander Peczenik, On Law and Reason, p. 29.

196 Cf. Carlos Bernal Pulido, "Grundrechtsprinzipien in Spanien: Rationalität und Grenzen der Abwägung", p. 206.

197 Cf. Virgílio Afonso da Silva, Grundrechte und gesetzgeberische Spielräume, pp. 103-104.

198 Cf. Cristóbal Orrego Sánchez, "La objetividad del derecho como función de la subjetividad/ objetividad del juez”, p. 602.

199 Cf. Enrique P. Haba, "Racionalidad y método para el derecho: ¿es eso posible? (I)”, p. 174. 
aplicado com a finalidade de obter ou confirmar conhecimentos acerca deles, ou bem de elaborar ou transformar ditos objetos; e tais procedimentos, se o método é correto, a experiência os acredita como adequados para a obtenção dos conhecimentos ou das realizações práticas assim perseguidas". ${ }^{200}$

A correção de um método diz respeito à possibilidade de controle da aplicação desse método. E isso ocorre, dentro do cenário descrito anteriormente, por meio de um controle intersubjetivo. Intersubjetividade do conhecimento significa que a verificação, o controle quanto à legitimidade de uma afirmação, dependerá de critérios que sejam firmes, no sentido de que as pessoas estarão habitualmente de acordo sobre a aplicação de ditos critérios, ou seja, acerca do grau de probabilidade e plausibilidade dos resultados obtidos em função de tais critérios. ${ }^{201}$ Por isso, o conhecimento científico é justamente aquele que é intersubjetivamente comunicável e controlável. ${ }^{202}$

A intersubjetividade não proporciona garantias absolutas para a argumentação jurídica, mas ela é o meio disponível para julgar de forma menos subjetiva em uma concepção de racionalidade em sentido fraco. ${ }^{203}$ Desse modo, é a intersubjetividade característica da obtenção do conhecimento racional, com a qual se trabalha nessa pesquisa. Um encadeamento de proposições será racional quando ele se fundamenta em: “a) cadeias conclusivas intersubjetivamente controláveis, b) orientadas até um fim de conhecimento compartido - de modo igualmente intersubjetivo - pelos encarregados de medir essa racionalidade, e de onde c) as conclusões respectivas alcançam - pelo menos em certa medida, mas sempre intersubjetivamente - aquela finalidade". ${ }^{204}$

O ponto a ser trabalhado corresponde ao desenvolvimento de um procedimento capaz de controlar se a decisão tomada, em cada um dos passos de sua argumentação, pode ser justificada, o que significa perguntar se é possível mostrar as razões que permitem considerar a decisão como aceitável e seu resultado como coerente com as premissas que a fundamentam. ${ }^{205}$ Assim, a racionalidade que se busca por meio de um método em uma decisão jurídica diz respeito à possibilidade de se justificar os argumentos apresentados,

\footnotetext{
200 Enrique P. Haba, "Racionalidad y método para el derecho: ¿es eso posible? (I)”, p. 175.

201 Cf. Enrique P. Haba, "Racionalidad y método para el derecho: ¿es eso posible? (I)”, p. 178.

202 Cf. Enrique P. Haba, "Racionalidad y método para el derecho: ¿es eso posible? (I)”, p. 179.

203 Cf. Enrique P. Haba, "Racionalidad y método para el derecho: ¿es eso posible? (I)”, p. 179.

204 Cf. Enrique P. Haba, "Racionalidad y método para el derecho: ¿es eso posible? (I)”, p. 184.

205 Cf. aponta Aulis Aarnio, "uma forma de pensar coerente e conseqüente está tão enraizado na nossa cultura que nós usamos isso como medida na avaliação do comportamento de outras pessoas. Nesse sentido, o conceito de coerência e consequiência são elementos necessários do nosso conceito comum de racionalidade". The rational as reasonable: a treatise on legal justification. Dordrecht: Reidel, 1987, p. 194.
} 
trazendo critérios e parâmetros que limitem a discricionariedade do juiz, não sendo uma decisão baseada puramente na vontade do julgador.

Com esse conceito de racionalidade em sentido fraco, também se rejeita uma pretensão de neutralidade e imparcialidade absoluta na aplicação dos métodos jurídicos, principalmente em relação ao sopesamento. ${ }^{206}$ Não se pretende analisar o sopesamento e sua estrutura como um método que exclua julgamentos de ordem moral por parte dos operadores do direito. A existência de opiniões pessoais dos juízes não significa que as decisões refletem puramente essas opiniões e suas vontades. Há as exigências de fundamentação e justificação.

Os critérios apontados dizem respeito à necessidade não só de um controle intersubjetivo, mas também um controle argumentativo para alcançar a pretensão de racionalidade definida nesse trabalho. Os dois controles se encontram diretamente relacionados, já que o controle argumentativo é feito por meio de um controle intersubjetivo. $^{207} \mathrm{O}$ direito exibe uma "moldura argumentativa" empregada pelos participantes em uma prática jurídica para mostrar a adequação de proposições jurídicas, e a objetividade em questão é um produto do uso dessa moldura. ${ }^{208}$

Um ponto que muitos autores apresentam como pressuposto e que Dennis Patterson trata como o "lugar-comum" nessa discussão é que todo entendimento é produzido por meio da interpretação, ou seja, as normas devem ser construídas, seu sentido não é dado no direito. Além disso, o sentido lingüístico de um texto pode ser instável, mesmo naqueles casos em que se pensa uma norma como um dado incapaz de gerar dúvidas ao aplicador. ${ }^{209}$ Por isso o autor sustenta que a objetividade para o direito é algo a ser construído e não achado. $^{210}$ A normatividade diz respeito não ao que faz os julgamentos corretos ou incorretos, mas no que esses julgamentos consistem. ${ }^{211}$

Desse modo, a normatividade do direito depende de uma identificável gramática de justificação (formas da argumentação jurídica) e consistente reconhecimento entre os

\footnotetext{
206 Em sentido contrário, autores como David M. Beatty, por exemplo, defendem o uso do sopesamento nas decisões justamente por sustentar o caráter da neutralidade do método. The Ultimate Rule of Law, p. 161. 207 Ou, em outras palavras, conforme Dennis Patterson: "the Grammar - the forms of legal argument is the intersubjective basis of legal judgment". "Normativity and Objectivity in Law", p. 361.

208 Cf. Dennis Patterson, "Normativity and Objectivity in Law", p. 328.

209 Um exemplo de controvérsia nesse sentido diz respeito ao caso do "estupro presumido", discutido no HC 73.662 no STF. De acordo com a antiga redação do Código Penal (revogada em 2009), presumia-se a violência se a vítima fosse menor de 14 anos (art. 224, a). No caso do STF, os ministros discutiram se essa presunção poderia valer nos casos em que a menor aparentasse ser maior de 14 anos e consentisse a relação sexual.

${ }_{210}$ Cf. Dennis Patterson, "Normativity and Objectivity in Law", p. 341.

211 Cf. Dennis Patterson, "Normativity and Objectivity in Law", p. 342.
} 
participantes na prática de que essas são as formas de avaliação jurídica. ${ }^{212}$ As normas jurídicas são objetivas no nível em que as formas de argumentação continuem a ser reconhecidas como formas legítimas de justificação. Isso porque a base para o juiz usar o seu poder de decidir está na aceitabilidade de suas decisões - o que se mede por meio da argumentação - e não na autoridade, ou uma posição de poder. ${ }^{213} \mathrm{~A}$ responsabilidade do juiz em justificar suas decisões corresponde especialmente à responsabilidade de maximizar o controle público de suas decisões. ${ }^{214}$

A partir da explicação e exposição desses conceitos, este capítulo analisará questões sobre o modelo de sopesamento com o qual se quer trabalhar e sua estrutura, examinando as críticas já apresentadas e as possibilidades de desenvolvimento de critérios racionais de decidibilidade, tendo por base os conceitos definidos nesse tópico.

\subsection{Modelo de sopesamento}

Tendo rejeitado uma pretensão de hiper-racionalidade para o método em estudo, cabe definir qual o modelo de sopesamento com o qual se pretende trabalhar, a fim de se examinar com detalhes qual é a sua estrutura. Muitas das críticas direcionadas, em sentido geral, ao sopesamento adotam o "exagero" como estratégia, tratando de uma "inflação de ponderação" ou "Estado de ponderação" presente no ordenamento jurídico atualmente. ${ }^{215}$ Essa crítica no sentido do exagero afirma o método como puramente arbitrário, preso a uma concepção decisionista do modelo de ponderação, ou seja, a uma definição do método em sentido amplo, como a simples ação de valorar e determinar preferências em relação a princípios colidentes. Observando desse modo, parece ser a ponderação um método desvinculado do desenvolvimento e apresentação de razões, se caracterizando apenas como a ação do julgador de preferir algo a outro, sem maiores justificações.

A questão é que o sopesamento pode ser concebido de várias formas. Giorgio Maniaci, por exemplo, aponta três principais formas de teorias do sopesamento: (1) sopesamento ad hoc; (2) sopesamento definitivo; (3) sopesamento "razoavelmente definitivo em sentido débil". ${ }^{216}$ O primeiro tipo corresponde justamente a esse modelo decisionista, que se fez referência anteriormente. Seria um modelo aplicado sem pretensões

\footnotetext{
212 Cf. Dennis Patterson, "Normativity and Objectivity in Law", p. 362.

213 Cf. Aulis Aarnio, The Rational as Reasonable, p. 6.

214 Cf. Aulis Aarnio, The Rational as Reasonable, p. 6.

215 Cf. Laura Clérico, El examen de proporcionalidad en el derecho constitucional, p. 295.

216 Cf. Giorgio Maniaci, "Algunas notas sobre coherencia y balance en la teoría de Robert Alexy". Isonomía 20 (2004).
} 
de universalizabilidade e sem preocupações em relação à fundamentação, na intenção de apenas resolver o caso concreto, sem maiores justificativas. $O$ juiz não identificaria ou não se mostraria comprometido em identificar uma ou mais propriedades relevantes que fossem condições suficientes da prevalência de um princípio sobre o outro, ficando um grau de indeterminação excessivo, uma fórmula vaga. ${ }^{217}$ É o modelo aplicado intuitivamente, por mera questão de preferências.

O segundo modelo de sopesamento apresentado por Giorgio Maniaci corresponde a modelo no qual o juiz faria referência a todas as circunstâncias nas quais um princípio prevaleceria sobre o outro. ${ }^{218}$ Nessa concepção, o juiz não se limitaria a identificar apenas uma propriedade ou um conjunto de propriedades que fossem condições suficientes para justificar a prevalência de um princípio, mas tentaria identificar todas as condições disjuntivamente suficientes da prevalência. Contudo, acredita-se que um modelo como esse não seria viável, já que não é nem possível nem é tarefa do juiz imaginar todas as situações nas quais um princípio prevaleceria sobre o outro. É uma pretensão não realizável, pois é empiricamente impossível para um agente conhecer todos os fatos passados e prever todas as contingências futuras. ${ }^{219}$

O terceiro modelo apresentado pelo autor corresponde a um sopesamento que, apesar de não oferecer ou ter a pretensão de oferecer uma solução normativa para todos os casos de colisão entre os princípios em questão, como no modelo anterior, se preocupa em justificar a preferência condicionada adotada, sobretudo satisfazendo de modo suficiente as regras de uma argumentação racional. ${ }^{220}$

Neste trabalho, acredita-se, em primeiro lugar, que a possibilidade de existência de critérios racionais de decidibilidade no sopesamento depende do modelo do método com o qual se trabalha. Nesse sentido, o sopesamento que aqui se considera corresponde a um modelo fundamentado, como o terceiro modelo apontado anteriormente. ${ }^{221}$ Rejeita-se um modelo decisionista (ad hoc), o qual geralmente é considerado pelos críticos em suas objeções. Neste modelo, pensar-se-ia que julgar é somente uma questão de vontade e não uma questão de razão. A tarefa do juiz é exatamente decidir sem ser decisionista, ou seja,

\footnotetext{
217 Cf. Giorgio Maniaci, “Algunas notas sobre coherencia y balance en la teoría de Robert Alexy”, p. 161.

218 Cf. Giorgio Maniaci, "Algunas notas sobre coherencia y balance en la teoría de Robert Alexy”, p. 163.

219 Cf. Giorgio Maniaci, “Algunas notas sobre coherencia y balance en la teoría de Robert Alexy”, p. 156.

220 Cf. Giorgio Maniaci, “Algunas notas sobre coherencia y balance en la teoría de Robert Alexy”, p. 164.

221 Cf. Robert Alexy, Teoria dos direitos fundamentais, pp. 164-165.
} 
potencializar ao máximo a explicação de seus argumentos e justificações, na consciência de que sua legitimidade provém da argumentação. ${ }^{222}$ Dessa maneira, o modelo aqui adotado não corresponde à pura intuição do aplicador do direito ao decidir qual direito deverá prevalecer em uma situação. Ao contrário, há a exigência de uma justificativa, de tal forma que o método obriga o juiz a expor qual foi o seu raciocínio, o que o levou a preferir um determinado direito, e não esconder a argumentação, como alguns críticos afirmam. Também se rejeita o modelo baseado em uma sobre-racionalidade, no qual o juiz faria referência a todas as circunstâncias nas quais um princípio prevaleceria sobre o outro.

Por isso, acredita-se que a crítica referente ao sopesamento como um método totalmente aberto, que abarca qualquer tipo de argumentação, não é procedente se for seguida essa delimitação. Outras objeções decorrem de um determinado conceito equivocado de sopesamento, como um método dito "neutro" e como se fosse possível aplicá-lo de forma geral, independentemente da observância dos contextos nos quais ele é aplicado.

A pretensão de neutralidade é o ponto mais delicado nessa crítica, pois se mostra difícil afirmar que um juiz não tinha preferências pré-determinadas antes de tomar qualquer decisão e que esta foi meramente guiada por um método. Como exemplo, cita-se o Ministro Marco Aurélio Mello, que disse expressamente em entrevista: "primeiro idealizo a solução mais justa. (...) Só depois vou buscar apoio na lei”. ${ }^{223}$ No mesmo sentido, em decisão do STF: "ao examinar a lide, o magistrado deve idealizar a solução mais justa, considerada a respectiva formação humanística. Somente após, cabe recorrer à dogmática para, encontrado o indispensável apoio, formalizá-la". ${ }^{224}$ Tentar sustentar o sopesamento como um método totalmente isento e com uma neutralidade absoluta não se mostra possível. Se assim fosse concebido, pareceria muito mais um esforço em esconder a decisão do juiz por meio dessa pretensão de neutralidade, representando um "esconderijo argumentativo".

Levando em consideração essas observações, é preciso focar-se em um modelo justificado de sopesamento. Esse modelo conduz a um resultado que corresponde a enunciado de preferência condicionada de princípios que, ao contrário do modelo

\footnotetext{
222 Sobre a questão decidir e ser decisionista, ver Manuel Atienza, El sentido del derecho, pp. 252 e ss.

223 Cf. Revista Análise - Justiça, 2006. Sobre as estratégias de decisão do Ministro Marco Aurélio, ver Bruna Romano Pretzel, $O$ Ministro Marco Aurélio e a liberdade de expressão: uma análise de argumentação. Monografia apresentada à Escola de Formação da Sociedade Brasileira de Direito Público, 2007.

${ }_{224}$ RE 111.787 e Bruna Romano Pretzel, O Ministro Marco Aurélio e a liberdade de expressão: uma análise de argumentação, p. 3.
} 
decisionista, no qual a definição do enunciado é o resultado de um processo psíquico não controlável racionalmente, nesse há diferenciação entre o enunciado de preferência e sua fundamentação. ${ }^{225}$ É justamente essa diferenciação que permite "ligar o postulado da racionalidade do sopesamento à fundamentação do enunciado de preferência". ${ }^{226}$ Isso porque um sopesamento pode satisfazer a condição da racionalidade quando o enunciado de preferência pode ser fundamentado de forma racional, ou seja, de maneira intersubjetivamente e argumentativamente controlável.

Nesse sentido, a pesquisa procura apontar possíveis caminhos para o desenvolvimento de um modelo justificado de sopesamento, a fim de se investigar as possibilidades de fundamentação do método e a existência de critérios racionais de decidibilidade a partir dos seguintes âmbitos, a serem analisados nos próximos tópicos: (1) no âmbito da fórmula do peso, que corresponde à resposta principal da questão aos críticos; (2) no âmbito do uso de critérios econômicos; (3) no âmbito da teoria do discurso e regras da argumentação jurídica; e (4) em relação a critérios complementares possíveis de serem desenvolvidos.

\subsection{Fórmula do peso}

A fórmula do peso representa uma maneira de se estruturar o raciocínio desenvolvido no sopesamento, a fim de se deixar mais claro como se procedem às comparações entre direitos e princípios por meio do método e tendo a pretensão de se chegar a um resultado por meio de critérios racionais de decidibilidade. Essa fórmula se vincula diretamente à lei do sopesamento. Seu enunciado corresponde ao seguinte raciocínio: "quanto maior for o grau de não-satisfação ou de afetação de um princípio, tanto maior terá que ser a importância da satisfação do outro". 227

Por meio da lei do sopesamento é possível visualizar o que é comparado no método: o grau de afetação ou restrição de um princípio ou direito, em relação ao grau de importância de satisfação do outro. Portanto não se trata de decidir entre dois direitos em abstrato, mas sim em uma situação concreta, na qual um direito sofre restrição, enquanto o outro é realizado. É exatamente essa relação que deve ser considerada no estabelecimento de uma comparação no sopesamento. A importância da fórmula do peso consiste no fato de

\footnotetext{
225 Cf. Robert Alexy, Teoria dos direitos fundamentais, p. 165.

226 Robert Alexy, Teoria dos direitos fundamentais, p. 165.

227 Cf. Robert Alexy, "Constitutional Rights, Balancing and Rationality", p. 136 e Teoria dos direitos fundamentais, p. 593.
} 
ela vincular parâmetros e permitir maior intersubjetividade no estabelecimento da decisão, pois por meio dela o raciocínio de escolha entre um princípio ou outro é mais detalhado do que uma simples preferência. Nesse sentido, ela representa argumento contrário aos críticos.

Outro ponto relevante, pressuposto para se entender qual a racionalidade possível do método, é que a fórmula do peso se enuncia dentro de uma tese moderada - e não radical - sobre conclusões racionais via sopesamento. A tese radical sustentaria que o sopesamento possibilitaria uma conclusão racional em todos os casos. Esse não é o ponto de vista a ser tratado, visto que a teoria dos princípios sempre considerou o sopesamento como um procedimento que não conduz a um resultado único e inequívoco em todo e qualquer caso $^{228}$. Já a tese moderada sustenta: “embora o sopesamento nem sempre determine um resultado de forma racional, isso é em alguns casos possível, e o conjunto desses casos é interessante o suficiente para justificar o sopesamento como método". ${ }^{229}$ É por meio desse ponto de vista que se desenvolve a fórmula do peso.

A fórmula é construída a partir de um modelo fundamentado do método. Para isso, a lei do sopesamento se divide em três passos. ${ }^{230}$ No primeiro é avaliado o grau de nãosatisfação ou afetação de um dos princípios. No segundo estágio, avalia-se a importância da satisfação do princípio colidente. Por fim, em um terceiro passo, deve ser avaliado se a importância da satisfação do princípio colidente justifica a afetação ou a não-satisfação do outro princípio.

A crítica de Habermas, segundo Alexy, justificar-se-ia se não fosse possível fazer julgamentos racionais sobre a intensidade da interferência, os graus de importância e sua relação entre si. Contudo, sustenta o autor que o método para obter tal racionalidade seria a construção de uma escala de valores, atribuindo aos princípios, conforme o caso concreto, um grau de interferência ou importância "leve" (1), "moderado" (m) e "sério" (s). ${ }^{231}$ A

\footnotetext{
228 Cf. Robert Alexy, Teoria dos direitos fundamentais, p. 594.

229 Cf. Robert Alexy, Teoria dos direitos fundamentais, p. 594. Interessante é relacionar essa tese com o argumento veiculado por David Luban em seu artigo sobre incomensurabilidade e incomparabilidade, em relação aos "large-small trade offs". Segundo o autor, nesses casos torna-se mais fácil se proceder a comparações. No entanto, nem sempre será possível tê-los, mas isso não implica que será sempre impossível se decidir um "trade-off' racionalmente. Ao contrário: é justamente a existência desses "trade-offs", nas quais é possível elencar razões e se decidir, que se justifica a utilização de raciocínios comparativos. Cf. David Luban, "Incommensurable Values, Rational Choice, and Moral Absolutes", pp. 76 e ss., e Virgílio Afonso da Silva, "Comparing the Incommensurable: Constitutional Principles, Balancing and Rational Decision", p. 11.

$230 \quad$ Cf. Robert Alexy, Teoria dos direitos fundamentais, p. 594 e "Constitutional Rights, Balancing, and Rationality", pp. 135 e ss.

231 Cf. Robert Alexy, Teoria dos direitos fundamentais, p. 595 e "La fórmula del peso", pp. 356 e ss. Também se usará as siglas entre parênteses para explicar a fórmula no texto a seguir.
} 
outra crítica de Habermas — "aplicação irrefletida" do sopesamento —, não teria fundamento, pois, apesar de os padrões para o sopesamento levarem em consideração sobretudo uma linha de precedentes, a sua aplicação ocorreria de forma argumentativa e não automática, considerando também a sua correção. ${ }^{232}$

Cabe aqui detalhar a fórmula do peso. Com isso é possível visualizar de maneira mais clara como a ponderação pode ser estruturada por meio de critérios racionais de decidibilidade, que explicitam a prática argumentativa desempenhada pelo aplicador do método. $^{233}$ Em primeiro lugar, como já exposto, parte-se de uma escala com três intensidades. ${ }^{234} \mathrm{Na}$ fórmula, se utiliza " $P i$ " como variável para o princípio que sofre a restrição e a intensidade da intervenção em $P i$ é simbolizada por "IPi". ${ }^{235} I P i$ representa uma grandeza concreta, porque intervenções a princípios serão sempre concretas. ${ }^{236}$ Desse modo ela é diferente do peso abstrato de Pi. Para diferenciar, mesmo sabendo que intervenções sempre serão concretas, pode-se utilizar a letra " $C$ " para simbolizar que se trata de um caso concreto: "IPiC". ${ }^{237}$

Além disso, há presente na fórmula a grandeza referente à importância da satisfação do outro direito em jogo. Contudo, segundo Alexy, ao contrário do que ocorre com a intensidade da intervenção, o grau de importância não necessariamente reflete sempre uma grandeza concreta, também se pode construí-lo por meio da reunião de uma grandeza concreta e outra abstrata. ${ }^{238}$ A questão é que, de forma muito freqüente, em colisões de direitos fundamentais, os pesos abstratos são iguais, não desempenhando papel relevante na decisão do sopesamento. Por isso, do mesmo modo, o autor determina uma variável específica para a importância concreta de um direito: "WPjC". ${ }^{239}$

Ressalva-se que a criação dessa escala com três categorias de graus de intervenção e importância de realização de princípios não representa tentativa de comensurar os direitos em questão. Ao contrário, o que se estabelece é uma escala ordinal em relação aos

\footnotetext{
232 Cf. Robert Alexy, Teoria dos direitos fundamentais, p. 599.

233 Nesse sentido, cf. Robert Alexy, "La formula del peso", p. 357.

234 Poder-se-ia utilizar um sistema com nove ao invés de três intensidades para avaliar os pesos dos direitos (por exemplo, uma intervenção leve leve, leve moderada, leve séria e assim sucessivamente). No entanto, acredita-se que essa estruturação acabaria sendo prejudicial para o desenvolvimento do método, pois criaria mais zonas de incerteza (torna-se mais difícil definir uma intervenção moderada moderada ou moderada leve, por exemplo, já que a diferença entre as intensidades é tênue) e acabaria por representar ainda que não com essa intenção inicial - uma tentativa de comensurabilidade que não é possível no caso. Conforme Alexy: "esses refinamentos têm seus limites. Embora eles possam, em tese, ser expandidos sempre mais, com isso o sistema fica cada vez mais incompreensível". Teoria dos direitos fundamentais, p. 610.

235 Cf. Robert Alexy, Teoria dos direitos fundamentais, p. 600 e "La fórmula del peso", pp. 357-358.

236 Cf. Robert Alexy, Teoria dos direitos fundamentais, p. 600 e "La fórmula del peso", p. 358.

237 Cf. Robert Alexy, Teoria dos direitos fundamentais, p. 600 e "La fórmula del peso", p. 358.

238 Cf. Robert Alexy, Teoria dos direitos fundamentais, p. 600 e "La fórmula del peso", p. 360.

239 Cf. Robert Alexy, Teoria dos direitos fundamentais, p. 600 e "La fórmula del peso", p. 360.
} 
graus e não aos princípios em si, apenas para funções argumentativas na aplicação do método, não havendo a pretensão de se estabelecer uma escala cardinal. Esse escalonamento permite que diferentes operadores do direito utilizem o método com base nos mesmos parâmetros em relação aos valores em jogo.

A partir dessas definições, o ponto controverso seria como determinar e avaliar o grau de intervenção em um direito e o grau da importância da realização do outro. Para isso, em primeiro lugar, acredita-se ser preciso levar em consideração os elementos essenciais do caso concreto, que são a medida questionada e os efeitos que sua adoção e sua não-adoção têm nos princípios envolvidos. ${ }^{240}$ Desse modo, em uma colisão envolvendo liberdade de expressão e direitos da personalidade, poder-se-ia determinar a intensidade da intervenção na liberdade de expressão por meio da indagação de quão intensamente sua proibição intervém no direito. ${ }^{241}$ Já em relação ao segundo direito, para determinar a importância da satisfação da proteção da personalidade se questiona o que a abstenção ou não-realização da intervenção na liberdade de expressão significaria para esse direito. ${ }^{242}$ Por isso, a avaliação acaba sendo, de certa forma, de via dupla, pois se considera o cenário presente e também o cenário exatamente contrário para determinar os graus no sopesamento.

Além disso, para determinar os pesos em jogo, se comparam outras situações de restrições ou realizações dos direitos na avaliação. Com isso é possível determinar critérios com base nos quais se estabelece se uma intervenção é séria, moderada ou leve. Para deixar mais claro, examina-se com mais detalhes a colisão clássica entre liberdade de expressão e privacidade. Exemplo: uma pessoa famosa teve fotos suas em diversas situações do seu cotidiano publicadas em revista. Essa pessoa, nesse caso, impetra uma ação contra a revista, por ter divulgado essas fotos, que implicaram violação de sua privacidade e direitos de personalidade conexos. Pretende a pessoa, por meio de tal ação, obrigar a revista a não mais publicar essas fotos e pagar indenização. Sua ação obteve sucesso. No entanto, a revista sentiu que sua liberdade de expressão foi limitada e, em conseqüência, interpõe recurso contra a adoção dessa medida. Como avaliar os pesos em jogo nesse conflito?

Pode-se argumentar, para determinar o grau da importância da realização ou não do direito à privacidade, se este é o mesmo para uma pessoa famosa ou para um mero

\footnotetext{
240 Cf. Robert Alexy, Teoria dos direitos fundamentais, p. 601.

241 Cf. Robert Alexy, Teoria dos direitos fundamentais, p. 601.

242 Cf. Robert Alexy, Teoria dos direitos fundamentais, p. 601.
} 
anônimo. $\mathrm{O}$ argumento seria que, por estarem pessoas famosas constantemente na mídia, o grau da importância da realização desse direito seria flexibilizado em relação a um anônimo, sendo avaliado com menor grau nesse caso. Isso não quer dizer que uma pessoa famosa possua "menor" privacidade do que um anônimo, mas que, em colisão com outros princípios, ela pode ceder com maior facilidade no caso. O critério de comparação seria então o tipo de pessoa fotografada.

Além disso, outro critério de comparação que pode ser estabelecido é o lugar no qual a foto foi tirada: se foi em lugar público, em região na qual qualquer outra pessoa que estivesse no local pudesse visualizar claramente a pessoa, então o grau de importância de realização da proteção da privacidade é menor do que no caso de a pessoa estar na sua casa, em lugar privado ou com restrições, como em um hotel ou restaurante, e não em uma praça pública ou em praia movimentada. Aqui o critério de comparação é o lugar. Por meio desses dois critérios, que comparam situações concretas e alternativas, poder-se-iam estabelecer os graus necessários na fórmula do sopesamento. ${ }^{243}$

A partir do estabelecimento do grau de intervenção de um princípio e o grau da importância da realização do outro, parte-se para a terceira e última fase da fórmula do peso. Nessa etapa estabelecem-se relações diretas entre os graus. A fórmula que expressaria o peso concreto de um direito conforme as variáveis expostas seria a seguinte:

$$
G P i, j C=I P i C / W P j C^{244}
$$

Dessa forma, nos seguintes cenários, $P i$ tem precedência em relação a $P j:{ }^{245}$

IPiC: s / WPjC: 1

$I P i C: \mathrm{s} / W P j C: \mathrm{m}$

IPiC: $\mathrm{m} /$ WPjC: 1 .

Invertendo-se as avaliações, têm-se as situações de prevalência de $P j$ ao invés de $P i$. Contudo, além desses seis casos, nos quais é possível apontar com maior facilidade qual princípio prevalece, há os casos de impasse no sopesamento, que ocorrem quando dois princípios são avaliados da mesma maneira, ou seja, casos de "empate":

\footnotetext{
243 Os critérios-exemplo de comparação tratados aqui foram baseados nos estudos de caso que realizei na minha iniciação científica ("direito à privacidade nas relações entre particulares"), sobre os casos Cicarelli e Caroline de Mônaco. Nesse trabalho pude examinar com maiores detalhes os critérios, as explicações e argumentos possíveis em situações como a descrita.

$244 \quad$ Aqui não se enunciam os pesos abstratos dos princípios, pois se os considera iguais. Contudo, no caso dos pesos serem distintos, acrescenta-se as variáveis GPiA, que representa o peso abstrato de Pi e GPjA, de Pj. Nesse caso a fórmula ficaria da seguinte maneira: GPi,jC =IPiC . GPiA / WPjC. GPjA. Como é possível observar por meio dessa enunciação, quando os pesos são iguais eles se anulam. Cf. Robert Alexy, Teoria dos direitos fundamentais, p. 604, nota 64.

${ }_{245}$ Cf. Robert Alexy, Teoria dos direitos fundamentais, p. 602 e ss. e "La formula del peso", p. 362.
} 
IPiC: $\mathrm{s} / W P j C: \mathrm{s}$

$I P i C: \mathrm{m} / W P j C: \mathrm{m}$

IPiC: $1 /$ WPjC: 1 .

Muitas vezes é exatamente com base nesses casos que os críticos fundamentam suas objeções à existência de critérios racionais de decidibilidade no sopesamento. Além disso, é preciso considerar que casos de impasse não dizem respeito somente a casos com avaliações de intensidade iguais, mas também a casos em que, embora haja uma pequena diferença entre as intensidades, não é possível distinguir qual dos graus é maior. E, para os críticos, isso seria também um problema para o método.

No entanto, em primeiro lugar, acredita-se que o fato de se ter avaliado os graus de intervenção e importância dos princípios desse modo não significa que não existam critérios racionais de decidibilidade. Ao contrário, só se pode chegar à conclusão de que os graus são iguais se se aplica à fórmula do peso, tendo desenvolvido os três passos formulados anteriormente. Essa observação é importante, pois afasta, também nos casos de impasse, as objeções provenientes da sustentação de uma incomparabilidade entre os direitos em colisão. Os direitos são comparáveis, no entanto eles foram avaliados de maneira igual ou quase igual. Em segundo lugar, para os casos em que não se pode distinguir exatamente quanto uma intensidade é maior que a outra, na terminologia de Ruth Chang, poder-se-ia dizer que os princípios se encontram em uma situação de paridade, como foi exposto anteriormente no trabalho.

Mostra-se interessante examinar mais atentamente esses casos de impasse. Segundo Alexy, poder-se-ia falar em dois casos de impasse: o primeiro, que decorre da estrutura normativa dos direitos fundamentais e leva a uma discricionariedade estrutural e o segundo, que surge somente porque as possibilidades cognitivas são limitadas e leva a uma discricionariedade epistêmica, vinculada à dificuldade de se identificar o que a constituição determina. Esses dois casos são importantes de serem analisados, pois representam um argumento contrário à objeção de Schlink e Böckenförde sobre separação de poderes e a não competência do tribunal constitucional para sopesar em qualquer situação.

Para diferenciar os impasses que decorrem da estrutura normativa desses direitos daqueles que surgem somente porque as possibilidades cognitivas são limitadas, Alexy procura analisar, por meio dos princípios formais, as diferenças entre as discricionariedades. Observam-se dois tipos de discricionariedade epistêmica: a empírica e a normativa. A primeira diz respeito à cognição de fatos relevantes. A segunda relaciona-se à "incerteza acerca da melhor quantificação dos direitos fundamentais em jogo e ao 
reconhecimento em favor do legislador de uma área no interior da qual ele pode tomar decisões com base em suas próprias valorações". ${ }^{246}$

O princípio formal que está em jogo é o da competência decisória do legislador democraticamente legitimado. É formal, porque não determina conteúdo, apenas diz quem deve definir conteúdos — espécie de "princípio procedimental". ${ }^{247}$ Ele determina quais decisões relevantes para a sociedade devem ser tomadas pelo legislador democraticamente legitimado. Nesse sentido, a tensão entre o princípio material e formal é, em última análise, a mesma que ocorre entre direitos fundamentais e democracia.

Se existisse uma precedência absoluta do princípio material de direito fundamental, a consequiência seria que o legislador somente poderia perseguir seus objetivos com base em premissas empíricas comprovadamente verdadeiras, o que praticamente nunca ocorre nos casos minimamente complexos. ${ }^{248}$ Em um cenário como esse, haveria pouca discricionariedade para o legislador, o que torna procedente as críticas nesse sentido. A outra solução extrema também não seria possível, pois daria permissão ao legislador para se basear "em prognósticos extremamente incertos e até mesmo intervenções muito intensas em direitos fundamentais". 249

Nesse ponto, Alexy é a favor de soluções intermediárias, que levam em consideração os diferentes graus de certeza dependentes das diferentes intervenções. Essa solução poderia ser definida pela "segunda lei do sopesamento": "quanto mais pesada for a intervenção em um direito fundamental, tanto maior terá que ser a certeza das premissas nas quais essa intervenção se baseia". ${ }^{250}$ Essa lei está associada à qualidade epistêmica das razões que sustentam a intervenção, e não se vincula à importância material das razões, que embasa a primeira lei.

A discricionariedade epistêmica normativa, por sua vez, está relacionada com a discricionariedade estrutural. Em um caso concreto, quando há impasse estrutural no sopesamento, é necessário apenas que os interesses em jogo sejam classificados como sendo de importância igual, para se chegar à conclusão de que tanto uma ação como outra estão inseridas na discricionariedade estrutural, pois ambas são facultadas ao legislador. ${ }^{251}$ O resultado é que os princípios de direitos fundamentais podem constituir objetos de 
sopesamento na discricionariedade estrutural, mas eles não podem determinar o sopesamento em razão do impasse.

A mesma situação pode ser construída com o auxílio de uma discricionariedade para sopesar do tipo epistêmico-normativo. É nesse ponto que ambas as discricionariedades se relacionam. A diferença, conforme Alexy, reside somente na nãoeliminação do elemento jurídico e na diversidade de possibilidades jurídicas. De um lado, o caso concreto se caracteriza como sendo fundamentável, ou seja, possível que os direitos fundamentais em jogo não só permitam como também obriguem determinada ação; de outro, considera-se impossível reconhecer qual das possibilidades pode ser mais bem fundamentada. Visto que há direitos fundamentais de ambos os lados, há entre eles um impasse epistêmico. ${ }^{252}$ Cada um dos direitos exige a solução mais vantajosa para si, mas nenhum deles possui, em razão do impasse, força para decidir o conflito. Por isso nesses casos pode se falar da existência de uma discricionariedade cognitiva também de tipo normativo. ${ }^{253}$ Os pesos dos princípios em colisão são incertos. ${ }^{254}$

Além dessas considerações, é possível a partir da lei epistêmica do sopesamento ampliar a fórmula do peso e acrescentar variáveis decorrentes dessa formulação. ${ }^{255} \mathrm{O}$ uso de escalas valeria também para averiguar a certeza das premissas nas quais uma intervenção em um direito fundamental se baseia. Insere-se, nesse sentido, a variável "segurança das suposições empíricas" $(S)$, que dizem respeito exatamente àquilo que as medidas em exame significam para a não-realização de $P i$ e para a realização de $P j$ no caso concreto. Desse modo, se analisam a certeza das premissas dos dois lados do sopesamento ( $S P i C$ e $S P j C)$. Os três níveis epistêmicos seriam: certo ou garantido $(\mathrm{g})$; sustentável ou plausível (p); e não evidentemente falso (e).

A expansão da fórmula do peso, com todas as variáveis comentadas, ficaria da seguinte forma:

$G P i, j C=I P i C . G P i A . S P i C$

IPjC . GPjA . SPjC

\subsection{Variações ou complementações do modelo de sopesamento e fórmula do peso}

\footnotetext{
$252 \quad$ Cf. Robert Alexy, Teoria dos direitos fundamentais, p. 622.

253 Cf. Robert Alexy, Teoria dos direitos fundamentais, p. 622.

$254 \quad$ Cf. Robert Alexy, Teoria dos direitos fundamentais, p. 625.

255 Cf. Robert Alexy, Teoria dos direitos fundamentais, p. 619, nota 97, e "La formula del peso", pp. 271 e ss.
} 
Uma parte do debate mais recente sobre a fórmula do peso concentra-se nas possibilidades de se ampliar sua estrutura ou traz mais detalhes para as variáveis já presentes. Esse é o caso de Carlos Bernal Pulido, ${ }^{256}$ por exemplo. O autor, que parte de conceito semelhante de racionalidade em sentido fraco abordado anteriormente pelo trabalho, diz que o âmbito de importância dos princípios depende de premissas normativas e fáticas e que, a partir de considerações sobre isso, é possível complementar a fórmula. ${ }^{257}$ Um primeiro tipo de premissa normativa que o autor defende é relacionada ao significado das posições dos princípios na sociedade. Tendo por base a teoria de Rawls, o autor fala que "quanto mais conectado com capacidades morais da pessoa a posição de um princípio é, maior importância deve ser atribuída ao princípio". ${ }^{258}$ Um segundo tipo de premissa normativa é a importância da posição legal em um caso, relacionada do ponto de vista do conteúdo dos princípios relevantes.

Já as premissas empíricas dizem respeito ao que a medida em questão significa para a importância dos princípios. $^{259}$ Desse modo, a importância depende da eficiência, velocidade, probabilidade, alcance e duração da medida que restringe direitos fundamentais. Por fim, o autor sugere que a mensuração do peso abstrato dos princípios no sopesamento de acordo com a escala em três níveis depende da busca pela melhor teoria substancial de constituição na qual o juiz se apoiará na decisão. Isso porque, dependendo do referencial teórico que o juiz levar em consideração, determinados direitos podem ser avaliados como de maior peso ou importância. ${ }^{260}$

Outro autor que parte do modelo da fórmula do peso e de sopesamento de Alexy é Jan Sieckmann, mas este defende um "modelo de otimização". Segundo o autor, "o modelo de otimização sugere que preferências entre argumentos normativos são determinadas por referência à importância relativa dos argumentos conflitantes no caso concreto". ${ }^{261} \mathrm{O}$ elemento central deste modelo é o critério de otimização de Pareto, que determina qual das

256 Cf. Carlos Bernal Pulido, "The Rationality of Balancing”, ARSP 93 (2006): 195-208, El principio de proporcionalidad y los derechos fundamentales. Madrid: Centro de Estudios Políticos y Constitucionales, 2003, e "On Alexy's Weight Formula", in A. J. Menéndez e E. O. Eriksen (eds.), Fundamental Rights through Discourse, Oslo: Arena, 2004.

257 Cf. Carlos Bernal Pulido, "The Rationality of Balancing".

258 Carlos Bernal Pulido, "The Rationality of Balancing"

259 Cf. Carlos Bernal Pulido, "The Rationality of Balancing"

260 Esse aspecto tratado sobre pesos abstratos possui relação com tópico seguinte, sobre critérios adicionais ao sopesamento, como se verá posteriormente.

261 Jan Sieckmann, "Balancing, Optimisation and Alexy's "Weight Formula"”, in IVR 2009: Legal Reasoning - the Methods of Balancing, Stuttgart: Franz Steiner, 2010, p. 102. 
soluções é a melhor entre as que são de fato possíveis. ${ }^{262}$ A principal diferença deste modelo com o de Alexy é que o autor trabalha com a idéia de pesos relacionais e não relacionais dos princípios em colisão, reformulando a composição da fórmula do peso. No entanto, a estrutura básica da fórmula do peso de Sieckmann é a mesma de Alexy.

Há também autores que se concentram em examinar atentamente a segunda lei do sopesamento e averiguar quais são as suas implicações, como Julian Rivers. ${ }^{263} \mathrm{O}$ autor faz considerações sobre os limites de atuação das cortes por meio da proporcionalidade e os tipos de discricionariedades do legislativo. Para ele, "quanto maior a chance de um princípio ser restringido, maior tem que ser a chance do outro ser realizado". ${ }^{264}$ Nesse sentido, a revisão judicial possível de ser realizada por meio do sopesamento e da proporcionalidade no geral pode ser medida em graus e o critério principal para isso é quanto mais sério for a restrição do direito, maior a liberdade da corte para questionar a medida elaborada pelo legislativo que interfere em direitos fundamentais. ${ }^{265}$

Assim, no caso de limitações substanciais e grandes em direitos fundamentais, o ganho para o interesse público também teria que ser grande e o órgão criador da medida teria que demonstrar que a efetivação do interesse público é assegurada no maior nível de certeza possível e persuadir a corte de que os custos para tanto realmente valem a pena. ${ }^{266}$ Essas são questões diretamente relacionadas à variável "certeza" da fórmula do peso. O autor conclui que um melhor entendimento da proporcionalidade seria como um "instrumento racional para a otimização dos interesses". ${ }^{267}$

Bartosz Brozek, ${ }^{268}$ por sua vez, faz uma análise vinculada a questões de teorias da argumentação, afirmando que a função da fórmula do peso corresponderia a um parâmetro para avaliar e comparar argumentos. ${ }^{269}$ Jean-Baptiste Pointel traça concepção alternativa do processo de sopesamento por meio da adoção de representação de vetores, partindo do raciocínio da fórmula do peso e estabelecendo uma análise algébrica das questões

262 Cf. Jan Sieckmann, "Balancing, Optimisation and Alexy's "Weight Formula"”, p. 103.

263 Cf. Julian Rivers, "Proportionality and Variable Intensity of Review", "Proportionality, Discretion and the Second Law of Balancing", in Law, Rights, Discourse: Themes the Work of Robert Alexy, Stanley Paulson \& George Pavlakos (eds.), Hart 2007 e "Proportionality and Discretion in International and European Law", in Nicholas Tsagourias (ed.), Transnational Constitutionalism, Cambridge: Cambridge University Press, 2007.

$264 \quad$ Julian Rivers, "Proportionality, Discretion and the Second Law of Balancing", p. 181.

265 Cf. Julian Rivers, "Proportionality and Variable Intensity of Review", p. 205.

266 Cf. Julian Rivers, "Proportionality and Variable Intensity of Review", p. 207.

267 Cf. Julian Rivers, "Proportionality and Variable Intensity of Review", p. 207.

268 Cf. Bartosz Brozek, "The Weight Formula and Argumentation", in Law, Rights, Discourse: Themes the Work of Robert Alexy, Stanley Paulson \& George Pavlakos (eds.), Hart 2007.

269 Mattias Kumm também comenta essa questão. Cf. "Political Liberalism and the Structures of Rights: On the Place and Limits of the Proportionality Requirement”,, in Law, Rights, Discourse: Themes the Work of Robert Alexy, Stanley Paulson \& George Pavlakos (eds.), Hart 2007. 
presentes na fórmula. ${ }^{270}$ Por fim, um recente trabalho sobre o desenvolvimento da fórmula do peso e os tipos de discricionariedades abordadas aqui é feito por Matthias Klatt e Johannes Schmidt. ${ }^{271}$ Os autores investigam problemas relacionados à segunda lei do sopesamento, como, por exemplo, qual escala deve ser aplicada para a variável S na fórmula do peso (segurança das premissas); como deve ser decidida a colisão entre direitos fundamentais quando a intensidade da restrição é incerta; e como funcionaria a segunda lei do sopesamento no caso de garantias de direitos fundamentais como prestações positivas. $^{272}$

Para responder a essas questões, os autores sugerem a utilização de uma escala de graus de segurança e não de plausibilidade. ${ }^{273}$ Além disso, estabelecem outro parâmetro para a fórmula do peso, no caso de haver dificuldade para estabelecer a intensidade da intervenção: "quanto mais certa for uma classificação mais intensa do grau de intervenção, então mais certa deve ser a classificação menos intensa do grau de intervenção". ${ }^{274}$ Isso corresponde para os autores à "lei da classificação".

Como é possível observar, os debates sobre a fórmula do peso não se esgotaram. ${ }^{275}$ Porém, nota-se que nessa discussão algumas questões acabam concentradas em aspectos muito específicos de variáveis da fórmula do peso, aspectos que não se pretende tratar com detalhes aqui.

\subsection{Uso de critérios econômicos no sopesamento}

Apesar de ser um autor crítico do sopesamento, Schlink também aborda o tema por meio do exame da possibilidade de se utilizar critérios econômicos no sopesamento. ${ }^{276}$ Isso

270 Cf. Jean-Baptiste Pointel, "Balancing in a Vector Space", in IVR 2009: Legal Reasoning - the Methods of Balancing, Stuttgart: Franz Steiner, 2010, p. 119.

271 Cf. Matthias Klatt e Johannes Schmidt, Spielräume im öffentlichen Recht: zur Abwägungslehre der Prinzipientheorie. Tübingen: Mohr Siebeck, 2010.

272 Cf. Matthias Klatt e Johannes Schmidt, Spielräume im öffentlichen Recht: zur Abwägungslehre der Prinzipientheorie, p. 16.

273 Cf. Matthias Klatt e Johannes Schmidt, Spielräume im öffentlichen Recht: zur Abwägungslehre der Prinzipientheorie, pp. 17-18.

274 Cf. Matthias Klatt e Johannes Schmidt, Spielräume im öffentlichen Recht: zur Abwägungslehre der Prinzipientheorie, p. 24.

275 Outro artigo sobre o debate, não citado anteriormente: José Juan Moreso, “Alexy y la aritmética de la ponderación", in Miguel Carbonell (org.), Proporcionalidad y la Interpretación Constitucional. Quito: Ministerio de Justicia y Derechos Humanos, 2008.

276 Outro autor que faz comentários sobre um modelo de sopesamento que recorre a "standards econômicos" é Nils Jansen, mas seu artigo, em certa maneira, caminha em sentido diverso do trabalho de Schlink. Cf. "Die Abwägung von Grundrechten", pp. 29 e ss. Sobre o uso de critérios econômicos nas ciências sociais no geral, ver: Thies Clausen, Rationalität und ökonomische Methode, Paderborn: Mentis, 2009. O livro aborda vários critérios de microeconomia que serão utilizados nesse tópico do trabalho. 
porque, para o autor, em relação a problemas de valores, há questões não somente para o Direito, mas também para outras ciências sociais, que podem ser aproveitadas no âmbito jurídico. Dessa forma, afirma que a relação dos problemas da economia e problemas do sopesamento no direito constitucional poderia ser feita de forma plausível.

A base para fazer essa relação é a idéia de que os problemas da economia do bem estar social são diretamente ou indiretamente problemas de divisão ou repartição de bens e garantias na sociedade. ${ }^{277}$ De certa maneira também assim se apresentam os problemas no sopesamento. A economia visa, nesse problema de repartição, maximizar o uso dos produtos e bens da sociedade em função dos indivíduos. O sopesamento opera na base da maximização de valores. Apesar de o autor afirmar que é possível que permaneça não definido o que é maximizado no sopesamento e que com um conceito geral não é possível gerenciar os problemas de distribuição de uma sociedade, o que importaria no caso seria a indicação de funcionalidade da correspondência para o direito constitucional da funcionalidade econômica do uso na sociedade. ${ }^{278}$

Então, os fundamentos da relação entre os problemas da economia do bem estar social e dos problemas do sopesamento seriam: (1) Os dois dizem respeito aos problemas das divisões ou distribuições; (2) Os dois dizem respeito à busca das distribuições que são úteis ou valorosas para a sociedade. ${ }^{279}$ Para realizar a medida da utilidade dos bens na sociedade e resolver problemas de distribuição, pode-se partir de duas formas de escala de preferências: a ordinal e a cardinal.

A escala ordinal mede os pesos por meio de avaliações de "mais" ou "menos", sem quantificação numérica específica. O que interessa, nesse caso, é a ordenação dos bens, saber que um é maior que o outro, estabelecendo apenas uma hierarquia entre esses bens. A escala ordinal funciona adequadamente para medir bens em relação a apenas um indivíduo, mas apresenta problemas no caso de avaliação de bens entre mais de uma pessoa. Isso acontece porque a escala ordinal não mede a intensidade das preferências das pessoas. ${ }^{280}$

Para explicar essa questão, Schlink usa como exemplo uma escala de preferência de bebidas: café, leite, suco, cerveja e vinho. ${ }^{281}$ Quatro indivíduos listam sua ordem de preferência. Schlink questiona que uma mera ordem de preferências pode não trazer

\footnotetext{
277 Cf. Bernhard Schlink, Abwägung im Verfassungsrecht, p. 156.

278 Cf. Bernhard Schlink, Abwägung im Verfassungsrecht, p. 157.

279 Cf. Bernhard Schlink, Abwägung im Verfassungsrecht, p. 157.

280 Cf. Bernhard Schlink, Abwägung im Verfassungsrecht, p. 160.

281 Cf. Bernhard Schlink, Abwägung im Verfassungsrecht, p. 159.
} 
informações suficientes, como, por exemplo, se é o caso do indivíduo 1 (I1) ser um escritor que trabalha até tarde e, por isso, estar o café em primeiro na sua lista; ou o caso do indivíduo 3 (I3) gostar na realidade de chá e não apreciar nenhuma das bebidas listadas. A escala ordinal é pouco sensível para aferir uma diferença de uso forte ou fraca das bebidas, ou seja, para aferir preferências e intensidade das escolhas. Desse modo, diferentes intensidades de uso, diferentes intensidades de preferências e propósitos não seriam expressivos em uma escala ordinal. ${ }^{282}$ A escala ordinal somente consegue ilustrar uma preferência social do indivíduo.

Nesse caso, surge a hipótese de uma escala cardinal. Para examiná-la, Schlink complementa o exemplo: o caso de alguém convidar dois desses indivíduos para uma festa e somente poder oferecer um dos tipos das bebidas listadas, tendo a disposição para escolha cerveja ou vinho. ${ }^{283}$ Em uma escala cardinal seria possível visualizar a intensidade das preferências, já que se poderia graduar e avaliar a situação com maior detalhamento do que em uma escala ordinal.

O problema que surge da constatação é justamente como operar com valores cardinais nessa escala proposta. Há duas medições em jogo: uma escala objetiva dos bens consumidos (uma taça de vinho, um copo de leite) e a medição subjetiva, que significa que o mesmo bem pode ter valores ou usos diferentes entre indivíduos. O ponto seria como determinar essa diferença. Se for possível determiná-la, não haveria problema com avaliações subjetivas que cada indivíduo atribui a um bem.

A solução para essa controvérsia seria a curva da indiferença. Segundo Schlink, "as dificuldades tanto da medição ordinal como cardinal de preferências se deixam entender que o objetivo de pesquisa econômico do bem estar social não é a investigação das preferências, mas a investigação sobre a indiferença dos indivíduos". ${ }^{284}$ Haveria a preocupação de se determinar o que significa cada bem para indivíduos diferentes, a fim de se tornar possível definir o ponto ótimo da divisão de bens na sociedade.

O instrumento com o qual os indiferencialistas procuram mostrar essa determinação são as curvas de indiferença com taxa marginal de substituição. ${ }^{285}$ As curvas da indiferença, na economia, são utilizadas para apresentar graficamente as preferências do

\footnotetext{
282 Cf. Bernhard Schlink, Abwägung im Verfassungsrecht, p. 160.

283 Cf. Bernhard Schlink, Abwägung im Verfassungsrecht, p. 164.

$284 \quad$ Bernhard Schlink, Abwägung im Verfassungsrecht, p. 168.

285 Cf. Bernhard Schlink, Abwägung im Verfassungsrecht, p. 168.
} 
consumidor. ${ }^{286}$ Representam todas as combinações de cestas de mercado ${ }^{287}$ que fornecem o mesmo nível de satisfação a um consumidor. Portanto, para ele, são indiferentes as cestas de mercado representadas pelos pontos ao longo da curva. Já a taxa marginal de substituição "mede a quantidade de determinada mercadoria da qual um consumidor estaria disposto a desistir para obter maior numero de outra", medindo, assim, o valor que um indivíduo atribui a uma unidade extra de um bem em termos de outro. ${ }^{288}$

É interessante observar que o raciocínio que se origina da taxa marginal de substituição pode ser de fato muito útil ao sopesamento. É possível ver isso por meio da explicação econômica, que aponta ser natural que as curvas de indiferença analisadas por Schlink sejam convexas (o autor examina casos concretos por meio de gráficos e tabelas, como na operação de ordem econômica). Isso ocorre porque "à medida que maiores quantidades de uma mercadoria são consumidas, esperamos que o consumidor prefira abrir mão de cada vez menos unidades de uma segunda mercadoria para poder obter unidades adicionais da primeira mercadoria". ${ }^{289}$ Assim, à medida que se percorre a curva de indiferença e o consumo de unidades de determinado bem aumenta, deve diminuir a satisfação adicional que o consumidor obtém ao adquirir unidades adicionais desse bem. Em outras palavras, ele estará disposto a desistir de cada vez menos unidades do outro bem para obter uma unidade adicional do primeiro bem em questão. Esse raciocínio encontra paralelo no sopesamento de princípios. À medida que um princípio é mais realizado e outro e mais restringido, a curva da indiferença apontada por Schlink diminui a “angulação": quando maior for a restrição, menor será o ganho para o indivíduo da realização do outro direito. ${ }^{290}$

É preciso, no entanto, descobrir qual é o ponto ótimo na curva da indiferença. Schlink analisa a tarefa do ponto de vista do ótimo de Pareto. O conceito de Pareto diz respeito à possibilidade de se encontrar uma forma de melhorar a situação de uma pessoa

\footnotetext{
286 Cf. Robert S. Pindyck e Daniel L. Rubinfeld. Microeconomia. 6ª Ed. São Paulo: Pearson, 2006, p. 58. 287 Cesta de mercado representa lista com quantidades específicas de um ou mais bens.

288 Cf. Robert S. Pindyck e Daniel L. Rubinfeld. Microeconomia, p. 61.

289 Robert S. Pindyck e Daniel L. Rubinfeld. Microeconomia, p. 62.

290 Alexy concorda, de certa maneira, nesse aspecto que as idéias por trás da lei do sopesamento podem ser ilustradas com o auxílio de curvas de indiferença. No entanto, para este autor, as curvas de indiferença não são diretamente equivalentes à lei do sopesamento, porque ela aponta, em primeiro lugar, para a importância de satisfação do princípio colidente e formula, em segundo lugar, um dever. Acredito que esse segundo ponto seja a maior diferença entre os dois autores, pois enquanto a curva apenas descreve substituições, no raciocínio via lei do sopesamento a preocupação é em relação à definição de qual deve ser a importância a se conferir aos princípios em jogo. Cf. Teoria dos direitos fundamentais, pp. 168-169.
} 
sem piorar a de nenhuma outra. ${ }^{291}$ Desse modo, "uma situação econômica é dita eficiente no sentido de Pareto se não existir nenhuma forma de melhorar a situação de uma pessoa sem piorar a de outra". ${ }^{292}$ O ponto negativo em se utilizar somente o ótimo de Pareto é que ele não consegue determinar soluções simétricas e assimétricas, avaliar quando a situação em jogo é assimétrica ou não em relação aos indivíduos.

Para essa abordagem, segundo Schlink, conceitos da teoria dos jogos e o critério Nash seriam adequados e complementariam o ótimo de Pareto. O autor não descarta a utilidade desse critério, porque ele filtra uma variedade de respostas, as quais, estando filtradas, são analisadas pela teoria dos jogos. Em linhas gerais, o objetivo da teoria dos jogos é procurar por estratégias de conflito otimizadoras para os envolvidos no conflito. ${ }^{293}$ O equilíbrio de Nash é atingido se, em um par de estratégias, a escolha do indivíduo 1 for ótima, dada a escolha do indivíduo 2 , e vice-versa. ${ }^{294}$

O que diferencia o critério Nash do de Pareto, segundo Schlink, é que, nas situações de conflito simétricas, são também as resoluções do conflito simétricas. ${ }^{295}$ No entanto, a avaliação sobre se uma situação é simétrica ou assimétrica não pode ser respondida sem uma comparação interpessoal dos jogadores. Mesmo assim, a comparação de uso pessoal mostra-se relevante para a justificativa da resolução por meio do critério de Nash. ${ }^{296}$

Com especial foco no âmbito do direito constitucional, Schlink reafirma o fato de que não existe nenhum método de interpretação que ordene os bens constitucionais de forma cardinal ou ordinal na Constituição e que o enfoque indiferencialista, assim como para as dificuldades presentes na economia, também é a resposta para as dificuldades de como resolver os problemas de valores no sopesamento. ${ }^{297} \mathrm{Na}$ curva da indiferença, quanto mais se perde de um lado, mais "caro" fica uma perda maior. Uma pequena perda da liberdade pode ser admissível, mas uma perda significativa será mais difícil de ser aceita e sua justificação será mais difícil de ser elaborada. ${ }^{298}$

\footnotetext{
291 Cf. Hal R. Varian, Microeconomia. 7. ed. Elsevier: 2006, pp. 15 e ss.

292 Hal R. Varian, Microeconomia, p. 329.

293 Bernhard Schink, Abwägung im Verfassungsrecht, p, 172.

294 Cf. Hal R. Varian, Microeconomia, p. 545.

295 Cf. Bernhard Schlink, Abwägung im Verfassungsrecht, p. 175.

296 Bernhard Schlink, Abwägung im Verfassungsrecht, p. 177.

297 Bernhard Schlink, Abwägung im Verfassungsrecht, p. 179.

298 Ressalva-se apenas que, apesar desta exposição, o autor continua a defender o sopesamento como uma operação típica do poder legislativo. Para ele, conforme exposto anteriormente, a escolha e pesagem de objetivos deve ser tarefa de uma instância política.
} 


\subsection{Exigências de racionalidade do discurso jurídico: regras da argumentação jurídica}

Procurar aperfeiçoamentos para o sopesamento diz respeito a investigar as possibilidades de fundamentação dos juízos ponderativos, assim como as pretensões de racionalidade, correção ou objetividade que se podem relacionar com isso. ${ }^{299}$ Significa também examinar o método tendo em mente as teorias da argumentação jurídica, procurando analisar até que ponto essas teorias poderiam complementá-lo na sua aplicação, já que a interpretação no direito é argumentativa. Por isso, nesse tópico pretende-se observar se seria possível agregar critérios no sopesamento por meio de uma teoria da argumentação ou não. ${ }^{300}$

Considera-se que o modelo do sopesamento como um todo oferece um critério, ao associar a lei da colisão e do sopesamento à teoria da argumentação jurídica racional. ${ }^{301}$ Essas leis mostram cada passo a ser desenvolvido no método e, desse modo, mostram também o que deve ser fundamentado. Assim, estão dadas linhas de argumentação para debilitar a objeção que diz que a ponderação é pura "arbitrariedade", fruto da "subjetividade" de quem a aplica, e que não se guia em caso concreto nenhum por uma "pauta racional". 302

Por isso, mostra-se relevante buscar orientações para a questão em exame também neste âmbito. A racionalidade possível do sopesamento está diretamente relacionada ao controle intersubjetivo e da argumentação desenvolvida na aplicação da técnica. Em resumo, como dito anteriormente, o modelo da ponderação oferece, ao menos, um procedimento para controlar se a decisão tomada em cada um dos casos pode ser justificada. ${ }^{303}$ Pode-se averiguar esse procedimento por meio da análise da argumentação desenvolvida na aplicação do método.

Em primeiro lugar, para analisar as possíveis contribuições das regras da argumentação jurídica para o método, é preciso observar regras mais gerais e que também valem para esse âmbito: as regras do discurso prático geral. Alexy, por exemplo, estabelece

\footnotetext{
299 Cf., Jan-R. Sieckmann, “Sobre la fundamentación de juicios ponderativos”, p. 159.

300 Por mais que alguns pontos a serem observados neste tópico dizerem respeito a exigências de fundamentação de qualquer juiz, creio que isso não diminua a relevância de se salientar estas questões ligadas à argumentação jurídica em relação ao sopesamento, principalmente considerando as críticas analisadas anteriormente no trabalho.

$301 \quad$ Cf. Robert Alexy, Teoria dos direitos fundamentais, p. 173.

302 Cf. Laura Clérico, El examen de proporcionalidad en el derecho constitucional, p. 197.

303 Cf. Laura Clérico, El examen de proporcionalidad en el derecho constitucional, p. 166.
} 
quatro regras fundamentais, ${ }^{304}$ que, se seguidas pelos juízes, haverá um ganho de coerência nas decisões. Dentre essas regras, o aspecto mais relevante para o trabalho diz respeito à enunciação de um princípio da universalização na argumentação. Esse é um possível argumento contra os críticos que afirmam a impossibilidade de acumulação de conhecimentos e a formação de uma "jurisprudência ad hoc" via sopesamento, sendo cada caso decidido isoladamente, por exemplo. ${ }^{305}$ Isso não aconteceria, porque o sopesamento, enquanto método inserido nas regras gerais da argumentação jurídica, teria como pressuposto no seu desenvolvimento uma pretensão de universalização dos argumentos. Quando um juiz decide uma colisão de direitos fundamentais ele não deve fazer isso pensando somente no caso concreto, mas sim com essa pretensão de universalização da sua decisão, ou seja, deve estar disposto a realizar a mesma ponderação caso a situação julgada se repita.

Se se chega à conclusão de que um determinado direito prevalece em uma situação, nos casos em que a mesma situação é reconhecida a mesma decisão deve ser tomada. Isso quer dizer, de modo simplificado, que não se chega a uma nova decisão a cada novo sopesamento, mas, à medida que cada vez mais sopesamentos são realizados e precedências são determinadas, o juiz, seguindo regras de coerência no discurso e argumentação jurídica, tem o ônus de observar essa rede de decisões já estabelecida. Em outras palavras, devem-se observar os precedentes que são formados a partir das resoluções das colisões entre direitos fundamentais. Importante ressaltar que esse argumento apresentado não trata de evitar sopesamentos, mas sim de aplicar os mesmos sopesamentos já consolidados a situações iguais, evitando-se a hipótese de uma "jurisprudência ad hoc" levantada pelos críticos e a total imprevisibilidade do resultado de decisões que envolvam a aplicação do método.

Essa idéia de um ônus existente em seguir precedentes também é formulada de maneira específica na teoria da argumentação jurídica de Alexy. Ele a fundamenta justamente no princípio da universalização, com base na concepção de justiça, enquanto concepção formal, de tratar de igual modo os iguais. ${ }^{306}$ É devido a esse princípio que se pode retirar de toda decisão jurídica alguma regra mais ou menos concreta em relação ao caso decidido. ${ }^{307}$ Além da igualdade, outros argumentos que sustentam a utilização de

\footnotetext{
$304 \quad$ Robert Alexy, Teoría de la argumentación jurídica, p. 185.

305 Por exemplo, objeções de Ladeur, tópico 4.6.

306 Cf. Robert Alexy, Teoría de la argumentación jurídica, p. 262.

307 Cf. Robert Alexy, Teoria dos direitos fundamentais, p. 556.
} 
precedentes são a segurança jurídica, a proteção da confiança, a redução da carga de trabalho e a estabilidade como base do desenvolvimento. ${ }^{308}$

É preciso considerar, no entanto, que casos nunca são idênticos, sempre há alguma diferença entre as decisões atuais e precedentes. Cabe ao juiz examinar até que ponto essas diferenças são relevantes e determinam ou não a aplicação do entendimento anterior consolidado. O relevante é que, havendo situações semelhantes, existe esse ônus para o operador do direito. ${ }^{309}$ Já nos casos em que a decisão anterior não se adequa a presente, há duas principais formas de se rejeitá-la: distinguindo os casos (distinguishing) ou superando o precedente, nos casos em que a situação é igual, porém a decisão é considerada inadequada (overruling). ${ }^{310}$ Contudo ressalta-se que, para averiguar a argumentação do juiz, é preciso observar de que maneira é feita a citação do precedente. Isso porque se pode fazer tanto uma analogia mais rígida ou aberta entre o caso presente e o passado, quanto uma utilização meramente retórica. ${ }^{311}$

Outro ponto a ser considerado é que, seguindo a tese de Alexy, o discurso jurídico é um caso especial de discurso prático geral e essa tese levanta a hipótese de haver uma pretensão de correção na argumentação jurídica. ${ }^{312}$ Essa questão é relevante para se considerar na estrutura e desenvolvimento do sopesamento, pois, apesar de o método não conduzir a uma única resposta correta, isso não significa que o juiz possa preencher a decisão de qualquer forma: há uma pretensão de correção que deve guiá-lo nos julgamentos.

Laura Clérico, por exemplo, fala em seu trabalho sobre a possibilidade de uma "correção procedimental", que significaria a busca de uma justificação "correta", no sentido de respeitar o procedimento de justificação indicado pela lei da ponderação. Isso seria diferente do conteúdo da relação de prioridade condicionada, ou seja, do resultado do sopesamento em si ser correto (nesse caso, seria uma “correção material”). Os juízes estão obrigados a fundamentar suas decisões e "quem fundamenta algo pretende que sua

\footnotetext{
$308 \quad$ Cf. Robert Alexy, Teoria dos direitos fundamentais, p. 556.

309 Regra J 13: "se é possível utilizar um precedente favorável ou contrário a uma decisão, ele deverá ser utilizado". Regra J 14: "aquele que pretende afastar o precedente tem o ônus argumentativo para tanto". Robert Alexy, Teoría de la argumentación jurídica.

310 Cf. Robert Alexy, Teoría de la argumentación jurídica, p. 266. Sobre uma discussão mais detalhada do tema, ver Neil MacCormick, Rhetoric and the Rule of Law. Oxford: Oxford University Press, 2005. Capítulo 8.

311 Sobre esses conceitos de citações de precedentes, ver Diego Lopez Medina, El derecho de los jueces: obligatoriedad del precedente constitucional, análisis de sentencias y líneas jurisprudenciales y teoría del derecho judicial, 2. ed., Bogotá: Legis, 2006.

$312 \quad$ Cf. Robert Alexy, Teoría de la argumentación jurídica, p. 206.
} 
fundamentação seja correta". ${ }^{313}$ Com isso se pretende chamar a atenção que os juízes não estão totalmente livres para decidir conforme sua vontade em questões de sopesamento. Não há completa arbitrariedade no desenvolvimento do método, como dizem alguns críticos, mas as próprias regras da argumentação jurídica já o limitam e impõem requisitos de modo geral à fundamentação a ser feita.

Por fim, uma diferenciação em relação à argumentação que pode ser útil ao trabalho diz respeito à justificativa interna e externa. A primeira examina se a decisão decorre logicamente das premissas que são levantadas como fundamentação, ${ }^{314}$ ou seja, se é possível chegar à conclusão por meio das premissas dispostas na argumentação, podendo qualquer juiz chegar ao mesmo resultado por meio das mesmas premissas. Isso diz respeito a uma consistência e coerência interna na decisão e é a estrutura básica da argumentação jurídica. Já a justificação externa tem como objeto a fundamentação das premissas usadas na justificação interna. ${ }^{315}$ Essas premissas podem ser de tipos distintos, como, por exemplo, regras do direito positivo ou enunciados empíricos. ${ }^{316}$

É importante considerar a justificação externa da argumentação, pois isso salienta que o juiz não toma uma decisão apenas com base na sua própria opinião ou de forma isolada, mas ele deve justificar as premissas expostas, e isso ocorre por meio de outros materiais que guiam a decisão: além dos precedentes já comentados com maiores detalhes, um julgamento se apóia em argumentos baseados nas constituições, tratados, leis dos parlamentos nacionais ou subnacionais, regulações e diretivas de entidades supranacionais, questões empíricas. Desse modo, aqueles que produzem argumentos e decisões jurídicas não abordam os problemas da decisão e da justificação no vácuo, mas, em vez disso, o fazem no contexto de uma pletora de materiais que servem para guiar e justificar decisões, e para restringir o espectro dentro do qual as decisões dos agentes públicos podem ser feitas legitimamente. ${ }^{317}$

\subsection{Modelo de sopesamento orientado por regras}

Considerando as observações do tópico anterior, principalmente a relacionada à pretensão de universalização no sopesamento, mostra-se interessante observar também um

\footnotetext{
313 Cf. Robert Alexy, Teoría de la argumentación jurídica, p. 208.

314 Cf. Robert Alexy, Teoría de la argumentación jurídica, p. 214.

315 Cf. Robert Alexy, Teoría de la argumentación jurídica, p. 222.

316 Cf. Robert Alexy, Teoría de la argumentación jurídica, p. 222.

317 Cf. Neil MacCormick, Retórica e Estado de direito, p. 31. Em sentido semelhante, Richard Posner, Problemas de Filosofia do Direito. São. Paulo: Martins Fontes, 2007, p. 176.
} 
"modelo orientado por regras", conforme definido por Laura Clérico, bem semelhante ao que já foi comentado anteriormente. ${ }^{318}$ Por meio da construção de que a partir da pretensão de universalização é possível formular o resultado dos sopesamentos como regra, a autora sustenta modelo de ponderação orientado por regras. Ele seria diferente de um modelo de ponderação no qual os resultados como regras não teriam importância e corresponderia ao "sopesamento ad hoc". Além disso, o modelo orientado por regras apresentaria uma solução intermediária entre dois modelos extremos: o "ad hoc", no qual não há formulação de regras dos resultados das decisões, e um modelo que não admite ponderação alguma. ${ }^{319}$

Com base nas regras da argumentação jurídica citadas sobre a utilização de precedentes, a autora as reformula de acordo com o desenvolvimento do sopesamento, tendo em mente a proporcionalidade em sentido estrito:

“(AR) Quando um meio é adequado tecnicamente, é o menos lesivo e há que se determinar se a restrição no direito fundamental que é causada pela medida estatal é proporcional em sentido estrito com o fim estatal e uma regra-resultado da ponderação apresenta semelhanças relevantes com as circunstâncias do caso, então essa regra deve ser considerada para a resolução da colisão e, se não se aplica, então é preciso justificar sua inaplicabilidade no caso concreto". 320

Para averiguar se uma regra-resultado da ponderação é aplicável para a solução de uma colisão de princípios, segundo Laura Clérico, trata-se de uma questão de comparação e possibilidade de justificação. ${ }^{321}$ A comparação é feita entre: o caso anterior decidido (Fv), a regra-resultado da ponderação aplicável (AWv), sua justificação (Bv) e o contexto dessa decisão (Kv); e, por outro lado, o caso que deve ser resolvido (F1), o atual contexto (K1), a hipotética regra-resultado da ponderação como solução do caso (AW1) e sua justificação (B1). ${ }^{322}$ Nesse sentido, durante a análise da aplicação ou não de uma regra resultado, desenvolvem-se dois tipos de pretensão: a de generalização, no caso de se enfatizar as semelhanças dos casos em exame, ou a de concretude, no caso de afastar a regra-resultado, ressaltando as diferenças entre os casos.

Cria-se, portanto, uma rede de regras-resultado dos sopesamentos, à semelhança de uma rede de precedentes. A vinculação dessas regras-resultado tem somente um caráter prima facie, de modo que elas podem ser afastadas, desde que justificado o porquê de não

\footnotetext{
318 Cf. Laura Clérico, El examen de proporcionalidad en el derecho constitucional, pp. 180 e ss.

319 Cf. Laura Clérico, El examen de proporcionalidad en el derecho constitucional, p. 181.

$320 \quad$ Laura Clérico, El examen de proporcionalidad en el derecho constitucional, p. 183.

321 Cf. Laura Clérico, El examen de proporcionalidad en el derecho constitucional, p. 183.

322 Laura Clérico, El examen de proporcionalidad en el derecho constitucional, pp. 183-184,
} 
se aplicá-las. Isso ocorre não somente quando os casos são distintos, mas também nos casos de se considerar a decisão anterior incorreta ou não justificável. ${ }^{323}$ Desse modo, não se trata de uma rede estática.

Além disso, é preciso considerar que as regras-resultado da ponderação supõem uma relação de precedência condicionada, que pode ser formulada a partir de diferentes graus de abstração e concretude. ${ }^{324}$ Isso vale também para a rede que é criada a partir dessas regras. Quando essas regras forem formuladas de maneira muito abstrata, as relações de precedência acabam servindo apenas como pontos de orientação e não como vinculações prima facie de determinada situação. Desse modo, segundo a autora, uma rede formada por regras-resultados construídas com poucos detalhes das condições de validade deve ser interpretada como uma rede que contém somente meros pontos de orientação. ${ }^{325}$ Se é possível construir essas regras de maneira mais concreta, então a rede deve ser interpretada como uma ordem de precedências prima facie.

Esse modelo de sopesamento guiado por regras, por meio da formação de uma rede de regras-resultado, pretende gerar maior continuidade e estabilidade para o ordenamento jurídico, possibilitando a previsão de soluções de colisões entre direitos fundamentais. Com isso, haveria ganho de confiança e aumento da segurança jurídica, não consolidando o cenário de total insegurança descrito pelos críticos devido ao uso do sopesamento. Criase uma prática constitucional estável, mas isso não significa uma petrificação para o ordenamento. O que o modelo da autora defende é uma aplicação crítica das regrasresultado e não automática, considerando ainda que se trate de uma vinculação prima facie, ou seja, é possível modificar o que foi determinado nas regras-resultados.

\subsection{Critérios complementares para guiar o sopesamento de forma racional}

Nesse tópico, pretende-se ressaltar critérios complementares, que se relacionam com as disposições já expostas anteriormente no trabalho, para guiar a aplicação do sopesamento. O primeiro diz respeito ao esclarecimento dos pressupostos teóricos da argumentação; ${ }^{326}$ o segundo, considerar as especificidades da dogmática de cada direito fundamental.

\footnotetext{
$323 \quad$ Laura Clérico, El examen de proporcionalidad en el derecho constitucional, p. 186.

$324 \quad$ Cf. Laura Clérico, El examen de proporcionalidad en el derecho constitucional, p. 188.

$325 \quad$ Laura Clérico, El examen de proporcionalidad en el derecho constitucional, p. 189.

326 Cf. Virgílio Afonso da Silva, "Ponderação e objetividade na interpretação constitucional", pp. 372 e
} SS.. 
O primeiro critério diz respeito a uma questão de justificação interna da decisão. $O$ esclarecimento da teoria que serve de premissa à decisão do juiz gera um ganho na consistência e coerência interna no julgamento. Se, por exemplo, um juiz tiver concepções liberais na economia, em uma decisão do tema, se ele partir de tal concepção, espera-se uma conclusão baseada nesse ponto de vista. No caso do juiz decidir de maneira diversa, ele deve fundamentar o porquê disso, apesar de ter visões mais liberais no âmbito econômico.

O segundo critério já foi comentado na pesquisa e diz respeito à importância de se buscar soluções tendo em vista qual o direito em questão. No exemplo sobre o direito à privacidade, observou-se que, considerando o direito em jogo e os casos concretos nos quais se pode examiná-lo, foi possível desenvolver mais critérios para a resolução das colisões de direitos fundamentais com base em características e situações envolvendo a privacidade.

\subsection{Parâmetros de controle para a sociedade}

Outro ponto que se considera diz que os parâmetros aqui tratados poderiam possibilitar maior controle por parte da sociedade sobre como os juízes desenvolvem o método em questão. ${ }^{327}$ Isso porque, por meio desses parâmetros e critérios, é possível distinguir os passos na argumentação jurídica que levam à decisão, identificando com maior clareza quais são os argumentos levantados no julgamento. Com isso, a sociedade dispõe de maiores instrumentos que possibilitam uma análise, debate e crítica das decisões do tribunal. Se o sopesamento fosse puramente subjetivo e irracional, não seria nem possível identificar essas questões, impossibilitando a formação de críticas a respeito do conteúdo de uma decisão.

Isso é importante, pois, se os tribunais constitucionais possuem a "última palavra" em casos difíceis, ${ }^{328}$ isso não significa que, por isso, os juízes possam decidir de qualquer modo. Além das exigências argumentativas já comentadas, relacionadas ao déficit de legitimidade democrática, a sociedade pode - e talvez devesse - acompanhar de perto as atividades desse tribunal, comentando e criticando-as. Isso faz parte da dinâmica de uma

327 Cf. Virgílio Afonso da Silva, "Ponderação e objetividade na interpretação constitucional", pp. 377 e SS..

Sobre debate relacionado à questão da "última palavra", ver, por exemplo, Conrado Hübner Mendes, Direitos fundamentais, separação de poderes e deliberação. São Paulo: tese de doutorado apresentada ao Departamento de Ciência Política na Faculdade de Filosofia, Letras e Ciências Humanas da Universidade de São Paulo, 2008. 
democracia. Além disso, esse ponto apresentado diz respeito a um aspecto da cultura jurídica de cada país.

No Brasil, essa cultura de acompanhamento das decisões do STF é relativamente recente, pois esse tipo de acompanhamento parece estar mais ligado ao legislativo do que ao judiciário no país. No entanto, com a chegada de casos altamente controversos na corte - como sobre pesquisas com células-tronco, aborto de anencéfalos, acesso a documentos públicos, interpretação da Lei de Anistia, ações afirmativas, estatuto do desarmamento, greve dos servidores públicos, demarcações de reservas indígenas ${ }^{329}$ - a sociedade tem prestado mais atenção e se mobilizado com maior freqüência para examinar criticamente o que vem sendo realizado no STF. Com isso, exigências de coerência e consistência provêm também de um acompanhamento crítico e pressão da sociedade sobre as atividades do tribunal constitucional. Esse controle seria feito não somente pela mídia ou movimentos sociais, mas também pelo debate acadêmico. ${ }^{330}$

329 Número das ações, respectivamente: ADI 3510, ADPF 54, ADI 4077, ADPF 153, ADI 3330, ADI 3112, MI 712, Pet 3338.

Cf. Virgílio Afonso da Silva, "Ponderação e objetividade na interpretação constitucional”, p. 377. 


\section{ESTUDO DE CASO - DECISÃO DE BUSCA DE DADOS PESSOAIS}

Após ter analisado o debate teórico sobre o sopesamento, sua estrutura e o desenvolvimento de critérios possíveis de racionalidade, pretende-se neste tópico observar como as questões previamente examinadas poderiam se revelar na prática. Para isso, o trabalho se concentrou em traçar estudo de caso, exposto a seguir.

\subsection{Contexto}

Logo após os ataques de 11 de setembro nos Estados Unidos, foram descobertos alguns terroristas envolvidos no planejamento e execução dos ataques com residência na Alemanha e estudando em universidades alemãs, como, por exemplo, a Universidade de Hamburgo. ${ }^{331}$ A descoberta gerou grande comoção no país, pois ninguém suspeitava de tais estudantes.

Após essa descoberta, alguns estados alemães aprovaram leis que permitiam a busca de dados pessoais, a fim de se procurar supostos terroristas que estariam planejando alguma ação. ${ }^{332} \mathrm{O}$ caso que chegou ao Tribunal Constitucional alemão questionava a autorização dos tribunais locais ${ }^{333}$ com base na lei do estado da Renânia do NorteVestfália, para a realização da busca de dados pessoais.

O método de buscas determinado pela lei em questão é um instrumento preventivo que determina perfis de suspeitos em possíveis ações futuras por meio do cruzamento de informações pessoais como, por exemplo, as obtidas por meio de registro de residência, conta no banco, idade, entre outros. Esse procedimento foi desenvolvido e utilizado em 1970 na Alemanha no combate ao terrorismo, mais especificamente a fim de se descobrir pessoas envolvidas na organização "Fração do Exército Vermelho" (RAF, na sigla em alemão). ${ }^{334}$ Como os terroristas da organização pagavam suas contas de eletricidade, telefone e aluguel em dinheiro, foi determinado que as companhias informassem quais dos

\footnotetext{
331 O caso mais conhecido é o de Mohammed Atta, um dos pilotos dos aviões sequiestrados nos atentados de 11 de setembro, que cursou arquitetura em Hamburgo.

$332 \quad$ Alguns estados que promulgaram leis nesse sentido após os atentados de 11 de setembro foram, por exemplo, Schleswig-Holstein e Baixa Saxônia. Cf. decisão 1 BvR 518/02 do Tribunal Constitucional alemão, p. 2. Dïsseldorf.

Os tribunais foram: Amtsgericht Düsseldorf, Landgericht Düsseldorf e Oberlandesgericht

334 Cf. Gabriele Kett-Straub, "Data Screening of Muslim Sleepers Unconstitutional", German Law Journal 11, p. 968.
} 
seus clientes pagavam os serviços em dinheiro e não em débito em conta, a fim de se encontrar pessoas com identidade falsa. ${ }^{335}$ Esses dados fornecidos foram cruzados com outras informações, formando-se, ao final, uma lista de possíveis membros do grupo. Com esses dados, a polícia investigou casas e apartamentos das pessoas na lista.

A lei com base na qual foi autorizada a busca pelos tribunais é a Lei de Polícia do Estado da Renânia do Norte-Vestfália (PolG - Polizeigesetz des Landes NordheinWestfalen), em seu art. 31. Tal artigo, em seu parágrafo $1^{\circ}$, diz que "é permitido que a polícia peça a transferência de dados pessoais e outros dados relacionados de certos grupos de pessoas armazenados em arquivos de instituições públicas e não públicas, em caso de necessidade, para defesa perante uma ameaça atual ou para a segurança do Estado ou dos estados federais ou da condição física, vida ou liberdade de uma pessoa”. A lei determina também que é necessária a autorização de um tribunal local, para que essa busca seja realizada. Em 2 de outubro de 2001 a busca foi autorizada pelo tribunal de Düsseldorf (Amtsgericht Düsseldorf) a pedido da direção de polícia de Düsseldorf. A ameaça atual foi justificada pelo fato de, após o 11 de setembro, o perigo de novos atentados continuarem atuais, já que os grupos extremistas responsáveis agiram nesse evento de forma internacional.

Com a busca autorizada, todas as repartições de registros de residência do Estado da Renânia do Norte-Vestfália, o órgão central de registros de estrangeiros em Colônia e as universidades no estado foram obrigados a transmitir dados de pessoas do sexo masculino, nascidas entre o período de $1^{\circ}$ de outubro de 1960 a $1^{\circ}$ de outubro de 1983 . O perfil procurado pela polícia como possíveis terroristas foi o de homem, com idade entre 18 e 40 anos, estudante ou que fora estudante em uma universidade alemã, de religião islâmica ${ }^{336} \mathrm{e}$ de país ou de nacionalidade de certos países com predominância de população islâmica. Foram transferidos, nessa busca, cerca de 5,2 milhões de dados.

Um estudante marroquino muçulmano questionou a autorização do tribunal de Düsseldorf para a busca de dados. Ele obteve respostas negativas tanto no tribunal de justiça (Landgericht Düsseldorf), quanto no tribunal superior (Oberlandesgericht Düsseldorf). A partir dessas negativas, ele impetrou reclamação no tribunal constitucional, tendo como argumento a violação do direito fundamental à autodeterminação da

335 Cf. Felix Müller e Tobias Richter, "Report on the Bundesverfassungsgericht's (Federal Constitucional Court) Jurisprudence in 2005/2006“, p. 179.

336 O dado "religião" é de fácil acesso na Alemanha, pois as pessoas, ao registrarem residência nas repartições públicas, precisam informar sua religião para se cadastrarem. 
informação (com base no art. 2 (1) e art. 1 (2) da Lei Fundamental da Alemanha). ${ }^{337}$ Além disso, sustentou a falta da existência de perigo atual para a busca de dados, pressuposto da própria lei.

\subsection{Aplicação do sopesamento para a resolução do caso}

Mostra-se interessante observar, por meio deste exemplo concreto, como o sopesamento pode ser desenvolvido na prática na argumentação judicial. Nesta decisão em específico, o tribunal procurou estabelecer critérios e buscar parâmetros para determinar, de um lado, as intensidades das intervenções e, de outro, a importância da realização dos direitos fundamentais em jogo, não sendo, deste modo, uma avaliação ou preferência arbitrária, mas justificada, conforme foi analisado durante o trabalho. Nesse processo de construção da fundamentação do caso, o tribunal buscou conceitos em suas próprias decisões, fazendo referências a vários precedentes e outros sopesamentos com os mesmos direitos, mas em outras situações. ${ }^{338}$ Pretende-se aqui examinar com detalhes a argumentação do caso e apontar a possibilidade de desenvolvimento do método por meio de critérios racionais de decidibilidade, conforme foi abordado na pesquisa.

$\mathrm{Na}$ colisão entre direitos fundamentais definida para o caso concreto, os bens a serem protegidos pela medida da busca de dados são a segurança dos estados e do Estado, assim como a integridade corporal, vida e liberdade dos cidadãos e, por outro lado, os princípios que sofrem restrição são a liberdade e o direito da autodeterminação informacional. O tribunal constitucional parte de um pressuposto e uma regra geral para analisar o conflito em questão: o de que "intervenções em direitos fundamentais que são intensas devem ser vistas antes a partir de níveis de suspeita ou de perigo determinados" e que "esse pressuposto é atendido pela busca de dados, quando o legislador liga a existência de um perigo concreto contra o bem ameaçado com a intervenção no direito fundamental".

Primeiramente o tribunal avalia o peso abstrato dos direitos em conflito, que é uma variável presente na fórmula do peso, abordada anteriormente no trabalho. Os bens a serem protegidos - segurança dos estados e do Estado, assim como integridade física, vida e

337 Art. 2 (1): "Todos têm o direito ao livre desenvolvimento de sua personalidade, na medida em que não violar os direitos dos outros, ou atente contra a ordem constitucional ou a lei moral”. Art. 1 (2): “O povo alemão reconhece os direitos humanos invioláveis e inalienáveis como base de toda comunidade, da paz e da justiça no mundo".

338 Desse modo, não é um sopesamento "ad hoc", como os críticos se referem, mas um sopesamento baseado nas decisões passadas, levando em consideração os conceitos que já foram estabelecidos pelo próprio tribunal. 
liberdade dos cidadãos - são de grande importância, de peso elevado. Por outro lado, o dever do Estado em proteger o disposto no art. 2 (2) 1 e art.1 (1) 2 da Lei Fundamental da Alemanha (proteção da vida e integridade física de uma pessoa) possui um grande peso. ${ }^{339}$ Igualmente para a liberdade de uma pessoa, no sentido do art. 2 (2) 2 da Lei Fundamental. ${ }^{340}$ É preciso considerar que o artigo da lei que possibilitou a autorização permite uma intervenção no direito da autodeterminação informacional com peso considerável.

A partir dessas observações, no intuito de investigar melhor a colisão, o tribunal desenvolve avaliação do peso concreto da intervenção do direito à autodeterminação informacional nesta situação da reclamação constitucional. Para isso, ele estabelece alguns critérios, como, por exemplo, de quantos sujeitos de direitos fundamentais são retirados dados por meio da medida, se os investigados dão alguma razão para a busca de informações, a extensão do dano individual em relação às pessoas que são investigadas, quão intensivo é o dano pelo qual a coletividade está exposta e sob quais pressupostos ou condições o dano pode acontecer. Para determinar isto, considera-se se os atingidos permanecem anônimos, quais informações são recolhidas, e quais são desvantagens das medidas eleitas contra os sujeitos de direitos fundamentais. O próprio tribunal afirma, em seguida, que esses são os critérios desenvolvidos por ele para o cálculo da intensidade da intervenção do direito fundamental relacionado à informação, desde as decisões sobre sigilo até as relacionadas à inviolabilidade do domicílio.

Com base em seus precedentes sobre os direitos em jogo, o tribunal diz que mesmo quando as informações encontradas pela busca de dados provocam uma interferência de intensidade baixa no direito de personalidade, como a busca intervém geralmente no âmbito de proteção do direito fundamental do art. 10, 1 e art. 13, 1 da lei fundamental, ${ }^{341}$ enquadra-se no caso de uma considerável intervenção no direito fundamental geral de autodeterminação informacional, além da avaliação conjunta necessária com as intervenções em vista da extensão da autorização da busca de dados, assim como as possibilidades de conexões variadas dos dados investigados. A primeira idéia, no sentido geral, serve de parâmetro para continuar a avaliação do grau de restrição do direito à autodeterminação.

\footnotetext{
339 Art. 2 (2) 1: "Todos tem o direito à vida e a integridade física"; art. 1 (1) 2: "A observação e a proteção da dignidade humana é obrigação de todos os poderes estatais".

$340 \quad$ Art. 2 (2) 2: "A liberdade individual é inviolável".

341 Art. 10 (1): "O sigilo da correspondência, assim como o sigilo das telecomunicações são invioláveis". Art. 13 (1): “O domicílio é inviolável”.
} 
Após essa observação geral, o tribunal se concentra na análise do critério “conteúdo" para examinar o grau da intervenção no direito fundamental. O peso da intervenção no direito a autodeterminação da informação depende dos conteúdos levantados, especialmente em qual o grau que as informações encontradas e suas conexões com outras atingem à relevância da personalidade e por quais caminhos esse conteúdo será derivado. Isso porque, por meio da autorização da busca de dados, intervenções em direitos fundamentais com peso considerável podem ocorrer, levando em consideração o conteúdo e a transmissão de dados, além das comparações dos dados transmitidos a serem estabelecidas, que podem, de certa maneira, gerar novos dados sobre as pessoas investigadas e aumentar a intensidade da intervenção no direito fundamental.

A lei com base na qual a autorização foi feita no caso concreto estabelece que não podem ser transmitidas informações sujeitas a sigilo profissional, não havendo limitação para a autorização de outros conteúdos, disponíveis tanto em instituições públicas como privadas. A autorização da lei abrange inclusive dados pessoais que possuem alto interesse na esfera privada do individuo, como a convicção religiosa. No caso em questão, o tribunal acredita que tanto pela variedade quanto pela extensão dos dados recolhidos foi autorizada pelo tribunal local uma intervenção de alta intensidade.

Com base nos dados possíveis de serem levantados, há na decisão a preocupação com a possibilidade de gerar um efeito estigmatizante para aqueles que preenchem os critérios de busca. No caso da busca de dados pós 11 de setembro de 2001, ela foi contra estrangeiros de determinadas origens e com crenças muçulmanas. A medida de investigação pode ter um efeito estigmatizador para os indivíduos e indiretamente aumentar o risco, no dia-a-dia ou na vida profissional, de serem discriminados. Os efeitos colaterais de se diferenciar uma religião e pessoas pertencentes a uma região aumentam o peso da intervenção no direito fundamental.

Há de se considerar, além disso, o risco de que esses dados circulem fora dos objetivos estatais. Mesmo com a não permissão da lei para se elaborar catálogos ou registros de perfis pessoais, o levantamento e junção dos dados podem levar à elaboração de um perfil pessoal e por meio disso possibilitar intervenções especialmente intensas. Isso é mais problemático no caso, pois, tendo em mente os critérios "número de pessoas atingidas" e "extensão de dados", a busca atingiu um grande número de pessoas, com 
grande extensão de dados. ${ }^{342}$ Em relação ao critério sobre se os investigados deram razão para tanto, aponta-se que muitas pessoas sequer despertavam qualquer suspeita. Neste caso específico, estabelece-se que o indivíduo é atingido de forma mais intensa em sua liberdade quanto menos ele mesmo dá razão para a intervenção estatal. Desse modo, é preciso considerar, para avaliar a busca de dados feita, não somente o número de pessoas relevantes, mas também o número total de pessoas atingidas. Quando não se tem critérios específicos, a busca pode recolher uma grande quantidade de dados de pessoas totalmente fora de qualquer suspeita.

A partir desse exame dos critérios, o tribunal procura comparar o caso presente com outra investigação anterior do mesmo tipo e fazer uma diferenciação. No caso, a busca de dados procurou descobrir terroristas que ainda não praticaram algum atentado, mas que possivelmente executarão uma ação no futuro. Para uma busca de dados como essa, é preciso aceitar a elaboração de perfis de criminosos relativos e não específicos e critérios de busca não específicos. Por isso que se trata de um caso diferente da busca de dados feita na década de 70 , que procurou membros do RAF, organização terrorista conhecida, com membros conhecidos, em ação com foco na busca destes criminosos já conhecidos.

O bem comum também é atingido e prejudicado nessa situação. Isso porque a autodeterminação é uma condição funcional elementar da capacidade de ação e de efeito do cidadão, fundada na comunidade democrática e com liberdades. Buscas de dados desse tipo geram risco de abuso e sensação de estar sendo vigiado.

No entanto, essas considerações não querem dizer por si só que a autorização da busca de dados em questão não é proporcional, diz o tribunal. A questão a ser analisada é se a intervenção se destina à prevenção de um perigo concreto e suficiente para o bem ameaçado. Assim começa o tribunal a avaliar o peso concreto da importância do bem jurídico a ser efetivado por meio da medida da busca de dados. Logo no início da decisão, o tribunal fala da importância abstrata, mas é por meio do conceito de perigo concreto que será definida a importância concreta. Reafirma-se aqui o dever do Estado em combater o terrorismo e o dever de preservação da ordem democrática e da liberdade da coletividade, mas se, por um lado, a efetivação da segurança é um objetivo estatal e este tem poderes para tanto, por outro é preciso que seja estabelecido um equilíbrio adequado entre liberdade dos indivíduos e segurança. O equilíbrio deve ser estabelecido entre a

342 Na decisão, o tribunal apresenta de forma clara os números de pessoas examinadas em várias fases das buscas e também a extensão exata dos dados, desde quais repartições públicas foram requisitadas, até os dados recolhidos. 
intensidade do dano ou prejuízo no direito fundamental e a intervenção relacionada aos elementos do suporte fático da lei, os fatos base necessários e o peso dos bens protegidos.

Levando em consideração o raciocínio acima, o argumento chave da decisão é o estabelecimento de que a medida de proteção somente será permitida nos casos de existência de um perigo concreto, já que o peso da intervenção em direitos fundamentais por meio do procedimento da busca de dados é grande. No caso em análise, diz o tribunal que os requisitos da proporcionalidade não são preenchidos pela busca de dados, pois não existe perigo concreto.

Para determinar essas avaliações, o tribunal estabelece parâmetro ligado à variável “certeza”, que está disposta na fórmula do peso, sobre a definição dos conceitos e das incertezas em relação aos fatos no sopesamento: "Quanto mais pesada for a ameaça ou o dano no bem jurídico [o bem jurídico a ser protegido, segurança dos cidadãos] e quanto menos pesada for a intervenção no direito fundamental [a autodeterminação informacional], menor deve ser a probabilidade, com a qual uma ameaça ou uma violação de um bem jurídico pode ser concretizada, e menores devem ser os fatos, os quais servem de base para a suspeita”.

Em outras palavras, se a intervenção no direito à autodeterminação for intensa, conforme os critérios citados anteriormente e abordados pelo tribunal, então a probabilidade de concretização da ameaça ou do dano deve ser alta e maiores devem ser os fatos que comprovam ou servem de base para a suspeita de dano futuro. Quanto maior for a intervenção no direito fundamental, maior é a exigência do grau de probabilidade e da base fundamentada dos fatos do prognóstico. Por isso, seguindo o raciocínio da decisão do tribunal, intervenções intensas em direitos fundamentais devem se destinar a níveis de suspeita e perigo determinados.

Contudo, o parágrafo 31 da lei do estado da Renânia do Norte-Vestfália estipula como elemento do suporte fático um perigo atual. A definição deste é "o perigo pelo qual o efeito do acontecimento danoso já começou ou o qual efeito imediato está para acontecer em tempo próximo, com uma probabilidade segura e bem delimitada." A existência de perigo atual, no entanto, não é uma obrigação de origem constitucional, segundo o tribunal. Comenta-se na decisão o problema de, ao se fazer uma busca de dados sob o requisito da ameaça ou perigo iminente, haver a possibilidade da medida ser empregada tarde demais. Para solucionar isso, o tribunal interpreta a lei como a necessidade de haver apenas um perigo concreto: "suficiente é quando o legislador conecta a admissibilidade da busca de dados com a necessidade de um perigo concreto para o bem jurídico em questão". O 
pressuposto é o grau de probabilidade que um dano ocorrerá no bem jurídico em tempo próximo. Por isso, é preciso realizar prognóstico da probabilidade, já que a mera suposição ou possibilidade vaga não são suficientes para justificar a intervenção.

No caso concreto, há a justificativa dos tribunais que concederam a autorização com base apenas em uma ameaça geral, decorrente dos atentados de 11 de setembro. Um perigo de terrorismo geral ou situações de tensão na política externa não bastam para uma ordem de busca de dados. Dessas situações gerais não houve conhecimento sobre perigos concretos, atentados ou ameaças na Alemanha. Por isso, decide o tribunal que "as decisões questionadas dão um conteúdo ao conceito de perigo atual da lei que não é suficiente. A existência de um perigo concreto pertence aos requisitos dos direitos fundamentais na autorização para a busca de dados, que é o conteúdo do conceito de perigo atual”.

Assim, o Tribunal Constitucional alemão acredita que "as decisões não dão atenção ao fato de que a proporcionalidade é vinculada à ordem de que exista ao menos um perigo concreto e, para isso, certo grau de probabilidade de violação de bem jurídico, tendo em vista não somente o tamanho do possível dano, mas também a gravidade e possibilidade de sucesso da intervenção a ser determinada, a qual será aplicada para defesa do perigo". Assim, conclui o tribunal que as decisões questionadas baseiam-se nessas deficiências constitucionais e, portanto, não são proporcionais.

Desse modo, podem-se visualizar de forma clara estruturas que analisei durante o trabalho como possíveis critérios racionais de decidibilidade do sopesamento, como, por exemplo, variáveis ligadas à fórmula do peso, para examinar e avaliar os pesos dos direitos em colisão e se proceder a uma escolha fundamentada, não sendo o método utilizado como um "esconderijo argumentativo" ou com aplicação meramente arbitrária.

O que se gostaria de salientar ao final deste estudo de caso é que mais importante é o desenvolvimento dessas variáveis por meio da aplicação do método. Não é necessário o tribunal dizer expressamente que aplicará a fórmula do peso segundo determinada doutrina ou autor específico, com explicações teóricas longas ou com descrições extensas sobre a origem do método. Na decisão do Tribunal Constitucional alemão, as únicas citações de literatura jurídica foram utilizadas para determinar novos conceitos ligados ao terrorismo, os quais ainda não haviam sido abordados em caso anterior. Não há necessidade de grandes teorizações metodológicas, mas sim a aplicação da teoria de forma clara na prática.

Um exemplo da atitude oposta pode facilitar o entendimento dessa abordagem. $\mathrm{O}$ STF, ao aplicar a proporcionalidade, normalmente refere-se a questões teóricas do método, 
sobre como ele deve ser aplicado, com citações explicativas de doutrina. Apesar disso, no conhecido caso Ellwanger (HC 82.424), ${ }^{343}$ não há desenvolvimento de argumentação na aplicação do método em si, revelando-se uma utilização pouco clara. O Ministro Gilmar Mendes, por exemplo, ao analisar a questão no habeas corpus, estrutura a proporcionalidade em sentido estrito sem maiores detalhes, dizendo que ambos os direitos em colisão são importantes: ele menciona, como direito a ser realizado, a preservação dos valores inerentes a uma sociedade pluralista e a dignidade humana e, como o princípio que sofre a intervenção, a liberdade de expressão. Contudo, ele não desenvolve maiores detalhes sobre o porquê, em sua opinião, que "é inegável que essa liberdade não alcança a intolerância racial e o estímulo a violência”.

Esse caso torna-se um exemplo negativo ainda mais forte se se considerar que os ministros nem conceituam de forma clara qual é a medida em exame (uns falam sobre a lei do racismo e a proibição dela, ${ }^{344}$ outros falam na prisão do paciente, que é o questionado no habeas corpus), nem a colisão de direitos fundamentais decorrente da aplicação de tal medida. A falta de argumentação clara nesse sentido dificulta uma aplicação do sopesamento por meio de critérios, já que não foi estabelecido nem o ponto de partida para a utilização do método.

Por fim, ressalva-se que o fato de ser possível estruturar um sopesamento por meio de critérios racionais de decidibilidade não quer dizer que a solução desta decisão seja a única resposta correta, que esse sopesamento aplicado conduza a uma resposta substantiva correta. Não é isso que se propõe com o método. É possível haver desacordo com as avaliações dos pesos, como inclusive houve nesse caso por meio do voto divergente da juíza Evelyn Haas. Ela partiu dos mesmos critérios, mas avaliou a situação em alguns pontos de forma diferente da maioria do tribunal.

\subsection{Resumo da estrutura da decisão analisada e seus critérios para o sopesamento}

(a) Medida questionada: decisões dos tribunais locais que autorizaram busca de dados com base em lei da Renânia do Norte-Vestfália;

343 O paciente Siegfried Ellwanger havia sido condenado pelo crime tipificado no art. 20 da Lei 7.716/89, com a redação dada pela Lei 8.081/90, por ter, na qualidade de escritor e sócio da empresa "Revisão Editora Ltda.", editado, distribuído e vendido ao público obras anti-semitas de sua autoria e de outros autores nacionais e estrangeiros.

344 Artigo 20, "caput", da Lei 7.716/89, com a redação dada pela Lei 8.081/90: "Praticar, induzir ou incitar, pelos meios de comunicação social ou por publicação de qualquer natureza, a discriminação ou preconceito de raça, religião, etnia ou procedência nacional. Pena: reclusão de dois a cinco anos". 
(b) Definição da colisão de direitos fundamentais: segurança do Estado, integridade física, vida e liberdade dos cidadãos (a serem realizados pela medida) X liberdade individual, direito à autodeterminação da informação (restringidos pela medida).

(c) Peso abstrato dos direitos fundamentais: considerável dos dois lados;

(d) Critérios para determinar o peso da intervenção e da importância de realização dos direitos fundamentais:

(1) Número dos sujeitos atingidos pela investigação: número elevado;

(2) Conteúdo dos dados: problema com o fator opção religiosa e nacionalidade, estigmatização;

(3) Se os investigados deram razões para a busca de informações: na maioria, não;

(4) A extensão do dano individual nas pessoas investigadas: grande, devido ao conteúdo;

(5) Extensão da autorização da busca de dados: grande; acesso a vários bancos de dados;

(6) Possibilidade de conexão dos dados: muitas conexões possíveis;

(7) Intensidade do dano pelo qual a coletividade está exposta: somente perigo abstrato;

(8) Pressupostos ou condições nas quais o dano pode ocorrer: não se sabe; probabilidade baseada apenas em perigo abstrato. 


\section{CONSIDERAÇÕES FINAIS}

Neste tópico final, não se pretende fazer uma lista de conclusões obtidas por meio dos estudos desenvolvidos na dissertação de mestrado. Evita-se, desse modo, a repetição e, sobretudo, os riscos de uma simplificação. Aqui, mostra-se relevante traçar algumas considerações finais sobre alguns aspectos da pesquisa.

Neste trabalho, procurou-se estudar o tema da ponderação, método muito utilizado por tribunais em diversos países para resolução de colisões entre direitos fundamentais, e a possibilidade do desenvolvimento de critérios racionais de decidibilidade, principalmente sob o enfoque dogmático analítico, mapeando o debate da literatura jurídica sobre esta questão. Por meio do acompanhamento do debate, tentou-se traçar um panorama das críticas do método e, levando-as em consideração, examinar qual modelo e estrutura de sopesamento poderiam permitir a aplicação do método por meio de critérios racionais de decidibilidade.

Desse modo, a pesquisa apontou a possibilidade da existência de um modelo justificado de sopesamento, diferente do modelo no qual muitas críticas se embasam, e abordou critérios e parâmetros que estariam incluídos em modelo como esse. Há ainda questões relacionadas a especificidades da teoria e do método em aberto, mas o objetivo deste trabalho foi examinar detalhadamente o debate, questionando aspectos gerais do método e aprofundando o seu estudo, já que é tão aplicado pelos tribunais, mas pouco é questionado sobre e como deveria ser a sua aplicação. 


\section{BIBLIOGRAFIA CITADA}

Aarnio, Aulis. The rational as reasonable: a treatise on legal justification. Dordrecht: Reidel, 1987.

Aleinikoff., T. Alexander. "Constitutional Law in the Age of Balancing", Yale Law Journal 96 (1987): 943-1005.

Alexy, Robert. Teoria dos direitos fundamentais. São Paulo: Malheiros, 2008.

. "Rechtsregeln und Rechtsprinzipien", in: Robert Alexy, Hans-Joachim Koch, Lothar Kuhlen, Helmut Rüßmann (Hsrg.), Elemente einer juristischen Begründungslehre. BadenBaden: Nomos, 2003.

. "Constitutional Rights, Balacing and Rationality”, Ratio Juris 2 (2003): 131-140.

Teoría de la argumentación jurídica. 2. ed. Madrid: Centro de Estudios Políticos y Constitucionales, 2007.

"La formula del peso", in Teoría de la argumentación jurídica. 2. ed. Madrid: Centro de Estudios Políticos y Constitucionales, 2007.

Atienza, Manuel El sentido del derecho. 3. ed. Barcelona: Ariel, 2007

Ávila, Humberto. Teoria dos princípios, São Paulo: Malheiros, 2003.

Barcellos, Ana Paula de, Ponderação, racionalidade e atividade jurisdicional. Rio de Janeiro: Renovar, 2005.

Beatty, David. The Ultimate Rule of Law. Oxford University Press: 2002

Bernal Pulido, Carlos "Grundrechtsprinzipien in Spanien: Rationalität und Grenzen der Abwägung", in Jan-R. Sieckmann, Die Prinzipientheorie der Grundrechte, Baden-Baden: Nomos, 2007.

_. "The Rationality of Balancing", ARSP 93 (2006): 195-208.

El principio de proporcionalidad y los derechos fundamentales. Madrid: Centro de Estudios Políticos y Constitucionales, 2003.

"On Alexy's Weight Formula", in A. J. Menéndez e E. O. Eriksen (eds.), Fundamental Rights through Discourse, Oslo: Arena, 2004.

Bickel, Alexander. The Least Dangerous Branch: The Supreme Court at the Bar of Politics. 2. ed. New Heaven: Yale University Press, 1986.

Böckenförde, Ernst-Wolfgang. "Grundrechtstheorie und Grundrechtsinterpretation", NJW 27 (1974): 1529-1538. 
_. "Grundrechtstheorie und Grundrechtsinterpretation", in Staat, Verfassung, Demokratie. Frankfurt am Main: Suhrkamp, 1991.

—. „Grundrechte als Grundsatznormen - zur gegenwärtigen Lage der Grundrechtsdogmatik“, in Ernst-Wolfgang Böckenförde (org.), Staat, Verfassung, Demokratie, Frankfurt a.M.: Suhrkamp, 1991: 159-199.

"Vier Thesen zur Kommunitarismus-Debatte", in Peter Siller / Bertram Keller (Hrsg.), Rechtsphilosophische Kontroversen der Gegenwart. Baden-Baden: Nomos, 1999.

Bomhoff, Jacco. "Balancing, the Global and the Local: Judicial Balancing as a Problematic Topic in Comparative (Constitutional) Law", Hastings International \& Comparative Law Review 31 (2008): 555-586.

Brady, Alan David Patrick. A Structural, Institutionally Sensitive Model of Proportionality and Deference under the Human Rights Act 1998, Tese de doutorado apresentada ao Departamento de Direito da London School of Economics, 2009.

Brozek, Bartosz. "The Weight Formula and Argumentation", in Law, Rights, Discourse: Themes the Work of Robert Alexy, Stanley Paulson \& George Pavlakos (eds.). Oxford: Hart, 2007.

Chang, Ruth. "Introdution", in Incommensurability, Incomparability and Practical Reason, Ruth Chang (ed.). Cambridge, Mass.: Harvard University Press, 1997.

_. "The Possibility of Parity", Ethics 112 (2002): 659-88.

Choudhry, Sujit. "Migration as a new metaphor in comparative constitutional law", in Sujit Choudhry (Ed.), The Migration of Constitutional Ideas. Cambridge: Cambridge University Press, 2006.

Christensen, Ralph e Fischer-Lescano, Andreas. Das Ganze des Rechts: Vom hierarchischen zum reflexiven Verständnis deutscher und europäischer Grundrechte. Berlin: Duncker \& Humblot, 2007.

Clausen, Thies. Rationalität und ökonomische Methode. Paderborn: Mentis, 2009,

Clérico, Laura. El examen de proporcionalidad em el derecho constitucional. Buenos Aires: Ed. Univ. de Buenos Aires, Eudeba, 2009.

Coffin, Frank M. "Judicial Balancing: The Protean Scales of Justice", New York University Law Review, 1988.

Conesa, Luisa. "The Tropicalization of Proportionality Balancing: The Colombian and Mexican Examples" (2008), Cornell Law School Inter-University Graduate Student Conference Papers, Paper 13. http://scholarship.law.cornell.edu/lps_clacp/13. Acesso em: 13.12.2010.

Dworkin, Ronald. Levando os direitos a sério. São Paulo: Martins Fontes, 2002. 
Finnis, John. "Natural Law and Legal Reasoning", Cleveland State Law Review 38 (1990): $1-13$.

Grimm, Dieter. "Proportionality in Canadian and German Constitutional Jurisprudence", University of Toronto Law Journal 57 (2007): 383-397.

Haba, Enrique P. "Racionalidad y método para el derecho: ¿es eso posible? (I)”, Doxa 7 (1990): 169-247.

Habermas, Jürgen. Between Facts and Norms. Cambridge, Mass.: MIT Press, 1998.

Jansen, Nils.“Die Abwägung von Grundrechten”, Der Staat 36 (1997).

Klafke, Guilherme Forma. "Pecados capitais no processo decisório do Supremo Tribunal Federal". Monografia apresentada à Escola de Formação da Sociedade Brasileira de Direito Público, 2010.

Klatt, Matthias e Schmidt, Johannes. Spielräume im öffentlichen Recht: zur Abwägungslehre der Prinzipientheorie. Tübingen: Mohr Siebeck, 2010.

Kelsen, Hans. Teoria pura do direito. São Paulo: Martins Fontes, 2003.

Kett-Straub, Gabriele. "Data Screening of Muslim Sleepers Unconstitutional", German Law Journal 11.

Kumm, Mattias "Political Liberalism and the Structure of Rights: On the Place and Limits of the Proportionality Requirement", in Law, Rights, Discourse: the Legal Philosophy of Robert Alexy, George Pavlakos (ed.). Oxford: Hart, 2007.

Ladeur, Karl-Heinz. Kritik der Abwägung in der Grundrechtsdogmatik. Tübingen: MohrSiebeck, 2004.

Lasser, Mitchel de S.-O.-L.'E. Judicial Deliberations: a Comparative Analysis of Judicial Transparancy and Legitimacy. Oxford: Oxford University Press, 2009.

Leisner, Walter. Die Abwägungsstaat. Berlin: Dunker \& Humboldt, 1997.

Luban, David. "Incommensurable Values, Rational Choice, and Moral Absolutes", Cleveland State Law Review 38 (1990): 65-83.

MacCormick, Neil. Retórica e Estado de direito, Rio de Janeiro: Elsevier, 2008,

Maniaci, Giorgio. "Algunas notas sobre coherencia y balance en la teoría de Robert Alexy”, Isonomia 20 (2004): 137-177.

Medina, Diego Lopez. El derecho de los jueces: obligatoriedad del precedente constitucional, análisis de sentencias y líneas jurisprudenciales y teoría del derecho judicial, 2. ed., Bogotá: Legis, 2006. 
Mendes, Conrado Hübner. Direitos fundamentais, separação de poderes e deliberação. São Paulo: tese de doutorado apresentada ao Departamento de Ciência Política na Faculdade de Filosofia, Letras e Ciências Humanas da Universidade de São Paulo, 2008.

Mendes, Gilmar Ferreira. Direitos fundamentais e controle de constitucionalidade. 2. ed., São Paulo: Celso Bastos: Instituto Brasileiro de Direito Constitucional, 1999

Moreso, José Juan. “Alexy y la aritmética de la ponderación”, in Miguel Carbonell (org.), Proporcionalidad y la Interpretación Constitucional. Quito: Ministerio de Justicia y Derechos Humanos, 2008.

Müller, Felix e Richter, Tobias. "Report on the Bundesverfassungsgericht's (Federal Constitucional Court) Jurisprudence in 2005/2006.

Oliveira, Ana Carolina de et al." Os desdobramentos da implantação do IPTU progressivo: uma análise interdisciplinar", Monografia apresentada ao concurso IPEA 2006.

Patterson, Dennis. "Normativity and Objectivity in Law", William \& Mary Law Review 43 (2001): 325-363.

Peczenik, Alexander. On Law and Reason. The Netherlands: Kluwer Academic Publishers, 1989.

Pereira, Bruno Ramos. O uso da proporcionalidade no Supremo Tribunal Federal. São Paulo: dissertação de mestrado, Faculdade de Direito da Universidade de São Paulo, 2009

Pindyck, Robert S. e Rubinfeld, Daniel L. Microeconomia. 6a. Ed. São Paulo: Pearson, 2006.

Pointel, Jean-Baptiste. "Balancing in a Vector Space", in IVR 2009: Legal Reasoning - the Methods of Balancing. Stuttgart: Franz Steiner, 2010

Posner, Richard. Problemas de Filosofia do Direito. São. Paulo: Martins Fontes, 2007.

Pretzel, Bruna Romano. O Ministro Marco Aurélio e a liberdade de expressão: uma análise de argumentação. Monografia apresentada à Escola de Formação da Sociedade Brasileira de Direito Público, 2007.

Rivers, Julian. „Proportionality and Variable Intensity of Review”, Cambridge Law Journal 65 (1) (2006): 174-207.

"Proportionality, Discretion and the Second Law of Balancing", in Law, Rights, Discourse: Themes the Work of Robert Alexy, Stanley Paulson \& George Pavlakos (eds.). Oxford: Hart, 2007.

. "Proportionality and Discretion in International and European Law", in Nicholas Tsagourias (ed.), Transnational Constitutionalism, Cambridge: Cambridge University Press, 2007. 
Rodriguez, José Rodrigo. "Argumento de autoridade, justiça opinativa e luta pela justificação no direito brasileiro", mimeo.

—. "O juiz e seus fantasmas: racionalidade jurisdicional, dogmática jurídica e democracia”. Working Paper Direito GV 45 (2009).

Sánchez, Cristóbal Orrego. "La objetividad del derecho como funcion de la subjetividad/ objetividad del juez", Revista de Derecho de la Pontificia Universidad Católica de Valparaíso 33 (2009): 599 - 619.

Sanchis, Luís Prieto "Neoconstitucionalismo y ponderacíon judicial”, in Miguel Carbonell, Neoconstitucionalismo(s). Madrid: Trotta, 2003.

Sarmento, Daniel. A ponderação de interesses na Constituição Federal. Rio de Janeiro: Lumen Juris, 2000.

Schlink, Bernhard. „German Constitutional Culture in Transition”, Cardozo Law Review 14 (1992-1993): 711-736.

. „The Dynamics of Constitutional Adjudication”, Cardozo Law Review 17 (19951996): 1231-.

. Abwägung im Verfassungsrecht. Berlin: Duncker \& Humblot, 1976.

—. "Der Grundsatz der Verhältinismäßigkeit", in: Festschrift 50 Jahre Bundesverfassungsgericht, Bd. 2, 2001.

- „Freiheit durch Eingriffsabwehr - Rekonstruktion der klassischen Grundrechtsfunktion“, Europäische Grundrechte-Zeitschrift 11 (1984): 457-468.

Sieckmann, Jan-R. “Argumentation und Abwägung”, ARSP 92 (2006).

. "Sobre la fundamentación de juicios ponderativos", in El modelo de los principios del derecho. Bogotá: Universidad Externado de Colombia, 2006.

. "Ponderación autónoma", in El modelo de los principios del derecho. Bogotá: Universidad Externado de Colombia, 2006.

"Corrección y objetividad en el modelo de principios", in El modelo de los principios del derecho. Bogotá: Universidad Externado de Colombia, 2006

"Balancing, Optimisation and Alexy's "Weight Formula"", in IVR 2009: Legal Reasoning - the Methods of Balancing. Stuttgart: Franz Steiner, 2010.

Silva, Virgílio Afonso da e Mendes, Conrado Hübner. "Habermas e a jurisdição constitucional", in Marcos Nobre e Ricardo Terra (org.), Direito e democracia. São Paulo: Malheiros, 2008.

Silva, Virgílio Afonso da. O conteúdo essencial dos direitos fundamentais e a eficácia das normas constitucionais. São Paulo: tese apresentada para o concurso de provas e títulos 
para provimento do cargo de Professor Titular, junto ao Departamento de Direito do Estado - área de direito constitucional - na Faculdade de Direito da Universidade de São Paulo, 2005.

_ _ "O proporcional e o razoável", Revista dos Tribunais 798 (2002): 23-50.

. "Princípios e regras: mitos e equívocos acerca de uma distinção", Revista LatinoAmericana de Estudos Constitucionais 1 (2003): 607-630.

. Grundrechte und gesetzgeberische Spielräume. Baden-Baden: Nomos, 2003.

"Comparing the Incommensurable: Constitutional Principles, Balancing and Rational Decision". Oxford Journal of Legal Studies (2011): 1-29.

. "Ponderação e objetividade na interpretação constitucional". In: Macedo Jr., Ronaldo Porto e Catarina Helena Cortada Barbieri (org.). Direito e interpretação: racionalidades e instituições. São Paulo: Saraiva, 2011.

"O STF e o controle de constitucionalidade: deliberação, diálogo e razão pública", Revista de Direito Administrativo 250 (2009): 197-227.

Starck, Christian. "Derechos fundamentales y derecho privado", Revista Española de Derecho Constitucional 66 (2002).

Steinmetz, Wilson. Colisão de direitos fundamentais e princípio da proporcionalidade. Porto Alegre: Livraria do Advogado, 2001.

Sweet, Alec Stone e Mathews, Jud. "Proportionality Balancing and Global Constitutionalism", Columbia Journal of Transnational Law 47.1 (2008). Disponível em: http://works.bepress.com/alec_stone_sweet/11/. Acesso: 26/10/2008.

Sunstein, Cass R. "Incommensurability and Kinds of Valuation", in Incommensurability, Incomparability and Practical Reason, Ruth Chang (ed.). Cambridge, Mass.: Harvard University Press, 1997.

Tsakyrakis, Stravros. "Proportionality: An assault on human rights?", International Journal of Constitutional Law 3 (2009): 468-493.

Varian, Hal. R. Microeconomia. 7. ed. Elsevier: 2006.

Waldron, Jeremy. "Fake Incommensurability: A Response to Professor Schauer". Hastings Law Journal 45 (1994).

Weber, Max. A "objetividade" do conhecimento nas ciências sociais. São Paulo: Ática, 2006.

Weinrib, Lorraine E. "The postwar paradigm and American exceptionalism", in The Migration of Constitutional Ideas, Sujit Choudhry (Ed.). Cambridge: Cambridge University Press, 2006. 
O objeto de estudo da presente dissertação corresponde ao sopesamento ou ponderação, método que vem sendo aplicado de modo freqüente em vários países para a resolução de colisões entre direitos fundamentais. Por ser altamente difundido atualmente, muitas vezes o cenário é caracterizado por uma aplicação irrefletida, ou seja, sem maiores questionamentos sobre o método em si. No entanto, existe grande discussão sobre o tema, principalmente sobre se é possível aplicar o sopesamento de forma racional.

Neste trabalho, o foco da pesquisa constitui exatamente analisar detalhadamente os problemas de aplicação do método, relacionados à possibilidade do desenvolvimento de critérios racionais de decidibilidade. Em outras palavras, procura-se examinar se é possível considerar o sopesamento um método racional na decisão de colisões entre direitos fundamentais, no intuito de se investigar as possibilidades de fundamentação dos juízos ponderativos, assim como as pretensões de racionalidade, correção ou objetividade que se podem relacionar à técnica. Para isso, a pesquisa examinou o debate teórico sobre sopesamento e, tendo em mente as críticas analisadas, foi realizada análise sobre o conceito de racionalidade possível no direito e sobre a estrutura e modelos de ponderação.

Palavras-chave: Ponderação, sopesamento, direitos fundamentais, método, argumentação. 


\begin{abstract}
The purpose of this paper is to analyze balancing or weighing rights, method that is frequently used worldwide in judicial decisions when principles collide. As its central position in the argumentation of many judicial decisions, the method is often used without a special reflection on its meaning and structure. Notwithstanding, there is a debate about the theme, mainly about if it is possible to use balancing rationally.

In this paper, the focus is to analyze the problems related to the method and to the possibility of developing rational criteria. In other words, I seek to examine whether it is possible to consider balancing as a rational method in judicial decisions involving collisions between fundamental rights, in order to investigate the possibilities of reasoning, as well as the claims of rationality, objectivity, or the structure that may relate to the procedure. For this, the research examined the theoretical debate on weighing rights and, after that, studied the concept of rationality possible in law and the structure of weighting models.
\end{abstract}

Keywords: Balancing, weighing rights, method, argumentation. 